University of Chicago Law School

Chicago Unbound

Journal Articles

Faculty Scholarship

1983

\title{
Implementing the Criminal Defendant's Right to Trial: Alternatives to the Plea Bargaining System
}

Albert W. Alschuler

Follow this and additional works at: https://chicagounbound.uchicago.edu/journal_articles

Part of the Law Commons

\section{Recommended Citation}

Albert Alschuler, "Implementing the Criminal Defendant's Right to Trial: Alternatives to the Plea Bargaining System," 50 University of Chicago Law Review 931 (1983).

This Article is brought to you for free and open access by the Faculty Scholarship at Chicago Unbound. It has been accepted for inclusion in Journal Articles by an authorized administrator of Chicago Unbound. For more information, please contact unbound@law.uchicago.edu. 


\section{The}

University

of Chicago

Law Review

VOLUME 50 NUMBER 3 SUMMER 1983

- 1983 by The University of Chicago

\section{Implementing the Criminal Defendant's Right to Trial: Alternatives to the Plea Bargaining System*}

\section{Albert W. Alschuler $\dagger$}

[T] he process of plea bargaining is not one which any student of the subject regards as an ornament to our system of justice.

Justice William H. Rehnquist ${ }^{2}$

The present state of affairs was brought about by willingness to reduce standards of justice to conform to the resources made available for its administration. I suggest the time has come for the judiciary to start moving in the other direction, and to insist on a return to first principles as quickly as possible.

Justice Charles L. Levin²

Those who predict disaster for our criminal courts system if we cease plea bargaining are really saying that the courts cannot provide a jury trial for all those who have a right to trial. If this assessment were true, then the courts should declare themselves bankrupt. ... But I do not believe the

* The preparation of this article was supported by Grant No. 79-NI-AX-0101 of the National Institute of Justice and by a Chicago Bar Foundation Fellowship at the Center for Studies in Criminal Justice of the University of Chicago Law School. I am grateful to the staff of the Institute and to Richard B. Collins, John H. Langbein, Mark Lowenstein, Norval Morris, Robert F. Nagel, William T. Pizzi, Stephen J. Schulhofer, Welsh S. White, Stephen F. Williams, and Franklin E. Zimring for their encouragement and valuable suggestions. Of course, the opinions and conclusions expressed in this article are simply my own.

$\dagger$ Professor of Law, University of Colorado.

1 Peterson, A Bad Bargain, Triar, May-June 1973, at 16, 16.

2 People v. Byrd, 12 Mich. App. 186, 223, 162 N.W.2d 777, 797 (1968) (Levin, J., concurring). 
courts system will collapse under the weight of too many trials if we abandon plea bargaining.

Judge Arthur L. Alarcon

In a series of articles, I have suggested some of the defects of plea bargaining. ${ }^{*}$ The task has been lengthy, for plea bargaining has come to affect almost every aspect of our criminal justice system from the legislative drafting of substantive offenses ${ }^{5}$ through the efforts of correctional officials to rehabilitate convicted offenders. ${ }^{6}$

Even a cursory listing of objections to this practice may consume several paragraphs. Plea bargaining makes a substantial part of an offender's sentence depend, not upon what he did or his personal characteristics, but upon a tactical decision irrelevant to any proper objective of criminal proceedings. ${ }^{7}$ In contested cases, it substitutes a regime of split-the-difference for a judicial determination of guilt or innocence and elevates a concept of partial guilt above the requirement that criminal responsibility be established beyond a reasonable doubt. ${ }^{8}$ This practice also deprecates the value of human liberty and the purposes of the criminal sanction by treating these things as commodities to be traded for economic savings-savings that, when measured against common social expenditures, usually seem minor. ${ }^{9}$

${ }^{3}$ Alarcon, Court Reform Would Solve the Problem, L.A. Times, Nov. 9, 1975, § 8, at 5, col. 4.

- Alschuler, The Changing Plea Bargaining Debate, 69 CALIr. L. REv. 652 (1981) [hereinafter cited as The Changing Debate]; Alschuler, Plea Bargaining and Its History, 79 Colum. L. Rev. 1 (1979) [hereinafter cited as History]; Alschuler, The Trial Judge's Role in Plea Bargaining (pt. 1), 76 Colum. L. REv. 1059 (1976) [hereinafter cited as The Trial Judge's Role]; Alschuler, The Prosecutor's Role in Plea Bargaining, 36 U. CHI. L. REv. 50 (1968) [hereinafter cited as The Prosecutor's Role]; Alschuler, The Supreme Court, the Defense Attorney, and the Guilty Plea, 47 U. CoLo. L. Rev. 1 (1975) [hereinafter cited as The Supreme Court]; Alschuler, Sentencing Reform and Prosecutorial Power: A Critique of Recent Proposals for "Fixed" and "Presumptive" Sentencing, 126 U. PA. L. REv. 550 (1978) [hereinafter cited as Sentencing Reform]; Alschuler, The Defense Attorney's Role in Plea Bargaining, 84 YALE L.J. 1179 (1975) [hereinafter cited as The Defense Attorney's Role]; Alschuler, Book Review, 12 Crim. L. BuLL. 629 (1976); Alschuler, Book Review, 66 LAw LIBR. J. 122 (1973); Alschuler, Book Review, 46 U. Chr. L. REv. 1007 (1979) (reviewing C. Silberman, Crmminal Violance, Criminal. Justice (1978)) [hereinafter cited as Silberman Book Review].

- See The Trial Judge's Role, supra note 4, at 1145-46.

- See J. Bennett, Of Prisons and Justice 124, 364-65 (1964); U.S. President's Comm'N ON Crime in the District of Columbia, Final Report 253-54 (1966) (statement of William E. Carr, Director, D.C. Dep't of Corrections); Snberman Book Review, supra note 4 , at 1041 .

Tee The Changing Debate, supra note 4, at 652-83.

${ }^{8}$ See id. at 703-07.

- See id. at 670-80. 
Plea bargaining leads lawyers to view themselves as judges and administrators rather than as advocates; it subjects them to serious financial and other temptations to disregard their clients' interests; and it diminishes the confidence in attorney-client relationships that can give dignity and purpose to the legal profession and that is essential to the defendant's sense of fair treatment. ${ }^{10}$ In addition, this practice makes figureheads of court officials who typically prepare elaborate presentence reports only after the effective determination of sentence through prosecutorial negotiations. ${ }^{11}$ Indeed, it tends to make figureheads of judges, whose power over the administration of criminal justice has largely been transferred to people of less experience, who commonly lack the information that judges could secure, whose temperaments have been shaped by their partisan duties, and who have not been charged by the electorate with the important responsibilities that they have assumed.12 Moreover, plea bargaining perverts both the initial prosecutorial formulation of criminal charges ${ }^{13}$ and, as defendants plead guilty to crimes less serious than those that they apparently committed, the final judicial labeling of offenses. ${ }^{14}$

The negotiation process encourages defendants to believe that they have "'sold a commodity and that [they have], in a sense, gotten away with something.' "'15 It sometimes promotes perceptions of corruption..$^{18}$ It has led the Supreme Court to a hypocritical disregard of its usual standards of waiver in judging the most pervasive waiver that our criminal justice system permits. ${ }^{17}$ The practice of plea bargaining is inconsistent with the principle that a

10 See The Defense Attorney's Role, supra note 4, at 1180, 1241, 1307-13.

"See The Trial Judge's Role, supra note 4, at 1117. A probation officer in Alaska described the frustration that she and her colleagues had experienced prior to the prohibition of plea bargaining by that state's Attorney General:

When we began to interview a defendant in order to prepare a presentence report, he would tell us what sentence he was going to get. And the defendant was always right. Even when we discovered significant new facts that the prosecutor and defense attorney hadn't known about at the time they struck their bargain, the judge disregarded them.

Interview with Karen Rogers, Probation-Parole Office of the Alaska Division of Corrections, in Juneau (June 22, 1976).

12 See The Trial Judge's Role, supra note 4, at 1063-67.

13 See The Prosecutor's Role, supra note 4, at 85-105.

14 See The Trial Judge's Role, supra note 4, at 1141-42.

is Silberman Book Review, supra note 4, at 1041 (quoting interview with J. Eugene Pincham, Private Defense Attorney, in Chicago (Dec. 15, 1967)).

16 See The Defense Attorney's Role, supra note 4, at 1197 n.55.

${ }_{17}$ See The Supreme Court, supra note 4, at 68-69; Halberstam, Toward Neutral Principles in the Administration of Criminal Justice: A Critique of Supreme Court Decisions Sanctioning the Plea Bargaining Process, 73 J. CRIM. L. \& ChIminology 1 (1982). 
decent society should want to hear what an accused person might say in his defense-and with constitutional guarantees that embody this principle and other professed ideals for the resolution of criminal disputes. ${ }^{18}$ Moreover, plea bargaining has undercut the goals of legal doctrines as diverse as the fourth amendment exclusionary rule, ${ }^{19}$ the insanity defense, ${ }^{20}$ the right of confrontation, ${ }^{21}$ the defendant's right to attend criminal proceedings, ${ }^{22}$ and the recently announced right of the press and the public to observe the administration of criminal justice. ${ }^{23}$ This easy instrument of accommodation has frustrated both attempts at sentencing reform ${ }^{24}$ and some of the most important objectives of the due process revolution. ${ }^{25}$

Plea bargaining provides extraordinary opportunities for lazy lawyers whose primary goal is to cut corners and to get on to the next case; ${ }^{26}$ it increases the likelihood of favoritism and personal influence; ${ }^{27}$ it conceals other abuses; ${ }^{28}$ it maximizes the dangers of representation by inexperienced attorneys who are not fully versed in an essentially secret system of justice; ${ }^{29}$ it promotes inequalities; ${ }^{30}$ it sometimes results in unwarranted leniency; ${ }^{31}$ it merges the tasks of adjudication, sentencing, and administration into a single amorphous judgment to the detriment of all three; $;^{32}$ it treats almost every legal right as a bargaining chip to be traded for a discount in sentence; ${ }^{33}$ and it almost certainly increases the number of innocent defendants who are convicted. ${ }^{34}$ In short, an effort to describe comprehensively the evils that plea bargaining has wrought requires an extensive tour of the criminal justice system.

18 See The Changing Debate, supra note 4, at 677; The Supreme Court, supra note 4, at $63-65$.

19 See The Changing Debate, supra note 4, at 711-13; The Prosecutor's Role, supra note 4 , at $82-83$.

${ }^{20}$ See The Prosecutor's Role, supra note 4, at 72-75.

${ }^{21}$ See The Trial Judge's Role, supra note 4, at 1127 n.226.

22 See id. at 1134-36.

2s See The Changing Debate, supra note 4, at 719-20.

24 See Sentencing Reform, supra note 4, at 563-77.

${ }^{23}$ See History, supra note 4, at 37-40.

${ }^{28}$ See The Changing Debate, supra note 4, at 690-92.

${ }^{27}$ See The Prosecutor's Role, supra note 4, at 71, 79-80, 94, 106; The Defense Attorney's Role, supra note 4, at 1219-24, 1237-40.

28 See The Prosecutor's Role, supra note 4, at 66-68.

19 See The Defense Attorney's Role, supra note 4, at 1268-70.

so See, e.g., The Changing Debate, supra note 4, at $653,657-58$.

31 See Silberman Book Review, supra note 4, at 1022-23.

32 See The Prosecutor's Role, supra note 4, at 52-53.

ss See The Changing Debate, supra note 4, at 657.

st See id. at 713-16. 
This is an article about exorcism. However unjust plea bargaining may seem, it has become fashionable to contend that the process is inevitable. Indeed, scholars and practitioners proclaim that "to speak of a plea bargaining-free criminal justice system is to operate in a land of fantasy."35 They advance two arguments in support of this contention. First, they emphasize the extent of the demon's possession. In view of the overwhelming number of cases that currently are resolved by guilty pleas, ${ }^{36}$ they maintain that providing the economic resources necessary to implement the right to trial would be impracticable; their view apparently is that our nation cannot afford to give its criminal defendants their day in court. ${ }^{37}$ Second, they suggest that in view of the mutuality of advantage that prosecutors and defense attorneys are likely to perceive in the settlement of criminal cases, any attempt to prohibit this process would be countered by widespread subterfuge. In practice, they argue, the only choice is between a system of negotiated case resolution that is open, honest, and subject to effective regulation and one that has been driven underground..$^{38}$

This article responds to these contentions and explores a range of reforms that might be implemented within the American

36 M. Hzumann, Plea Bargaining 162 (1978).

${ }^{38}$ It is commonly estimated that $90 \%$ of all criminal convictions in the United States are by pleas of guilty. Cramer, Rossman \& McDonald, The Judicial Role in Plea-Bargaining, in Plen Bargaining 139, 139 (W. McDonald \& J. Cramer eds. 1980).

${ }^{27}$ See, e.g., Santobello v. New York, 404 U.S. 257, 260 (1971) (plea bargaining is an "essential component of the administration of justice. . . . If every charge were subjected to a full-scale trial, the states and federal government would need to multiply by many times the number of judges and court facilities."); People v. Griffith, 43 A.D.2d 20, 22, 349 N.Y.S.2d 94, 97 (1973) (elimination of plea bargaining would result in "total breakdown" of the courts' operations); M. MAYER, Thr LAwYERS 159 (1967) ("If even one percent of [the defendants arraigned in Manhattan] were actually to proceed to full-fledged trial, the system would break down instantly."); Arenella, Reforming the Federal Grand Jury and the State Preliminary Hearing to Prevent Conviction Without Adjudication, 78 Mrch. L. Rev. 463, 524 (1980) ("the criminal justice system would collapse"); Welch, Settling Criminal Cases, Litigation, Winter 1980, at 32, 32 ("our court system would be crushed by the caseload"); White, A Proposal for Reform of the Plea Bargaining Process, 119 U. PA. L. REv. 439, 440 (1971) ("Removal of the incentive to plead guilty would place an intolerable strain on the system."); George, Book Review, 65 Mich. L. REv. 815, 817 (1967) ("It is futile to talk of abolishing [plea bargaining and judicial acquittals] unless we prefer the alternative of complete breakdown of the system.").

ss See, e.g., FED. R. CRIM. P. 11(e)(6) advisory committee note; Gifford, Meaningful Reform of Plea Bargaining: The Control of Prosecutorial Discretion, 1983 U. ILL. L. REv. 37, 74 n.10, 96; Rosett, The Negotiated Guilty Plea, 374 Annass 70, 74 (1967); The Supreme Court, 1978 Term, 93 HAnv. L. Rgv. 60, 81 (1979); Simon, Judge Explains Why He Backs Open Plea Bargaining System, Chicago Sun-Times, Jan. 15, 1975, at 8, col. 1 (statement of Judge Richard J. Fitzgerald: "[B]y necessity plea bargaining will always be with us. ... If they passed a law saying you can't have it, you'd still have it secretly because it simply exists."). 
criminal justice system to end an unjust practice. Part I examines one obvious solution to today's excessive dependency on the guilty plea-spending the money necessary to implement our constitutional ideals without shortcuts. Focusing first on felony prosecutions, it argues that the United States could provide three-day jury trials to all felony defendants who reach the trial stage by adding no more than an estimated $\$ 850$ million to annual criminal justice expenditures. Moreover, it contends that the actual cost of implementing a plea bargaining prohibition would be less than this amount, in part because most cases now resolved through plea bargaining could be tried in less than three days and, even more importantly, because many defendants would plead guilty without bargaining. The article then turns to misdemeanor prosecutions and proposes a short-form nontrial procedure modeled after the West German penal order. It argues that this procedure could permit the prohibition both of explicit plea bargaining and of implicit sentencing concessions for pleas of guilty without any significant increase in the amount that Americans now spend on misdemeanor justice. Part I ends by discussing the enforcement of a plea bargaining prohibition, contending that although evasions of this prohibition might not be suppressed altogether, they could be kept within tolerable limits.

Part II takes a different approach. It examines the relationship between the complexity of our trial procedures and our plea bargaining practices, and it describes some reforms that might permit the termination of plea bargaining even in felony cases without an increase in resources. This part notes initially both that the Anglo-American legal system afforded defendants an unfettered right to trial during most of its history and that most legal systems of the world apparently survive without plea bargaining today. Nevertheless, every legal system that has managed without plea bargaining has employed a much more expeditious trial procedure than ours. After a brief review of our own history and a more extensive description of current practices in other nations, the article considers how American trial procedures might be simplified in the interest of making trials more available to defendants who want them. The article argues that, contrary to common understanding, the federal Constitution as interpreted by the Supreme Court would not preclude the substitution of mixed tribunals of professional and lay judges for criminal juries in state court proceedings. It discusses additional innovations that might accompany this reform, some of them controversial and perhaps even startling, but worthy of serious consideration even apart from their facilitation 
of a plea bargaining prohibition.

Recognizing that reconsideration of the right to jury trial and of other central facets of American trial procedure is unlikely in the foreseeable future, the article also discusses a number of less sweeping proposals that already have some currency in the American legal system. It notes that each of these reforms could conserve substantial resources that might be used to implement the right to trial.

Finally, the article suggests that a less restrictive form of bargaining could be substituted for plea bargaining-bargaining for waiver of the right to jury trial but not for waiver of the right to trial before a court. Analysis of this alternative begins with a description of practices in Philadelphia and Pittsburgh, where to a large extent this substitution has occurred. A concluding section suggests that this "jury waiver bargaining" could be coupled with sentencing guidelines in an effort to treat together two issues that merit unified treatment, sentencing reform and plea negotiation. ${ }^{30}$

\section{Matching the Reality of Criminal Justice to Constitutional IDEaLs}

\section{A. Toward Full Implementation of the Right to Jury Trial in Fel- ony Cases}

The frequent claim that our nation cannot afford to provide jury trials to all defendants who want them and are entitled to them is unattractive. Chief Justice Burger wrote in 1971, "An affluent society ought not be miserly in support of justice, for economy is not an objective of the system." said, "No one should challenge any expense to afford a defendant full due process and his full measure of days in court."41 Moreover, the Supreme Court has said that "the Constitution recognizes higher values than speed and efficiency,"42 that to " "secure greater speed, economy, and convenience in the administration of the law at the price of fundamental principles" is to pay too high a

"Among the sources relied upon in this article are interviews with prosecutors, defense attorneys, trial judges, academics, and other observers of the criminal justice system. Statements that appear in quotation marks are not always exact quotations. I have attempted to recreate in a concise, readable, and accurate way what the persons I interviewed told me. My paraphrasing has rarely been extensive, and I hope and believe that it has retained both the substance and the style of the men and women with whom I talked.

10 Mayer v. City of Chicago, 404 U.S. 189, 201 (1971) (Burger, C.J., concurring).

11 Burger, "No Man Is an Island," 56 A.B.A. J. 325, 325 (1970).

12 Stanley v. Illinois, 405 U.S. 645, 656 (1972) (footnote omitted). 
price, ${ }^{43}$ that "[c]ongestion in the courts cannot justify a legal rule that produces unjust results," 14 and that "administrative convenience alone is insufficient to make valid what otherwise is a violation of due process of law."4s

Those who assert this idealistic and undoubtedly excessive position seem to tremble, however, when they confront some perceived realities of the plea bargaining process. Chief Justice Burger, for example, said of America's lopsided dependency on the guilty plea:

The consequence of what might seem on its face a small percentage change in the rate of guilty pleas can be tremendous. A reduction from 90 per cent to 80 per cent in guilty pleas requires the assignment of twice the judicial manpower and facilities-judges, court reporters, bailiffs, clerks, jurors and courtrooms. A reduction to 70 per cent trebles this demand. ${ }^{46}$

Although the Chief Justice's analysis has been often repeated, ${ }^{47}$ in some respects it is fallacious. It is commonly estimated that $90 \%$ of all criminal convictions in America are by guilty plea, ${ }^{48}$ but guilty pleas do not occur in anything close to $90 \%$ of all criminal prosecutions. One federally sponsored study of thirteen state court jurisdictions reported, for example, that guilty pleas accounted for $85 \%$ of the convictions in cases commenced by felony arrests but for only $53 \%$ of the dispositions of filed cases. ${ }^{48}$ Somewhat surprisingly, cases that end in dismissal appear to be more costly to the criminal justice system than cases that end either in guilty pleas or in nonjury trials. ${ }^{\text {s0 }}$ The Chief Justice's projection of

4s Bruton v. United States, 391 U.S. 123, 135 (1968) (quoting People v. Fisher, 249 N.Y. $419,432,164$ N.E. 336, 341 (1928) (Lehman, J., dissenting)).

11 United States v. Reliable Transfer Co., 421 U.S. 397, 408 (1975).

1s Cleveland Bd. of Educ. v. Lafleur, 414 U.S. 632, 647 (1974) (footnote omitted).

16 Burger, The State of the Judiciary-1970, 56 A.B.A. J. 929, 931 (1970).

47 See, e.g., Arenella, supra note 37 , at 524; Parnas \& Atkins, Abolishing Plea Bargaining: A Proposal, 14 CRIM. L. Burl. 101, 117 (1978).

48 See supra note 36.

4 K. Brosi, A Cross-City Comparison of Felony Case Processing 35 (1979) (percentages derived from aggregate of the individual jurisdictions shown).

so A dismissal commonly occurs after a hearing on a motion to suppress evidence or after some other judicial proceeding. A study based on California data found that the cost to the Superior Court of a case dismissed before trial or transferred to another jurisdiction was $\$ 1444$. Although lower than the cost of a case that ended in a jury trial (\$1772), this cost was greater than the cost of a case resolved by a nonjury trial ( $\$ 844)$ or by a plea of guilty (\$250). D. Weller \& M. Block, Estimating the Cost of Judicial Services 6, 8 (May 1979) (unpublished technical report CERDCR-1-79 of the Center for Econometric Studies of the Justice System of the Hoover Institution, Stanford University, on file with The University of Chicago Law Review). See also Castillo, New York Courts Found to Lag in Focusing on 
what increases in criminal justice expenditures would be necessary if plea bargaining were reduced neglected the very significant resources consumed by the many cases that do not end in conviction. ${ }^{51}$

Moreover, even when one focuses only on those cases that end in conviction, the Chief Justice's assertion that a reduction in the rate of guilty pleas from ninety to eighty percent would require a doubling of manpower and facilities apparently rested on the assumption that the plea bargaining system consumes only negligible resources. In reality, the bargaining process leads to substantial expenditures of resources, many of which seem difficult to justify in a supposedly overburdened system.

The bargaining process has increasingly been surrounded by time-consuming courtroom rituals whose function seems more the appeasement of troubled consciences than any genuine safeguarding of the quality of guilty plea justice. ${ }^{\mathbf{} 2}$ Moreover, plea bargaining has led defense attorneys to file absurd pretrial motions simply because "it takes time to refute even a bad contention" and "every motion added to the pile helps secure a better plea." prosecutors to inflate and multiply criminal charges so that, when defendants refuse to yield, trials are lengthy and complex. ${ }^{54}$ This

Dangerous Crime, N.Y. Times, Oct. 19, 1980, $\S 1$, at 1, col. 1 to 28, col. 2 ("The city's criminal justice system spends more- $\$ 945$-in processing an arrest that results in a dismissal, than in processing an arrest resulting in imprisonment. ... The cost of the latter, on the average, is $\$ 877 . ")$.

s1 These cases include not only prosecutions that are dismissed before trial, see supra note 50 , but also cases of acquittal at trial that obviously consume substantial resources.

${ }^{82}$ I have observed half-hour and 45-minute guilty plea proceedings in which defendants have been instructed about some aspects of criminal procedure that I do not discuss in a full semester course on that subject. The defendants have been advised of their right to challenge the jurisdiction of the court, of their right to challenge jurors for cause, of their right to peremptory challenges, of the fact that juries must be unanimous to convict, of the fact that juries must be unanimous to acquit, and so on (and on). The defendants have been asked to affirm after each advisement that they understand it. It generally is regarded as coercive for a trial judge to tell a guilty plea defendant the thing that he most wants to know-the sentence that will follow his plea. See The Trial Judge's Role, supra note 4, at 1087-91, 1103-08. Nevertheless, judges routinely tell guilty plea defendants many things that they do not want to know at all.

Professor Stephen J. Schulhofer has estimated on the basis of Philadelphia data that the entry and acceptance of a guilty plea consumes about 55 minutes of courtroom time (with both waiting time and processing time included); this figure excludes the courtroom time devoted to preliminary hearings, hearings on motions, and delayed sentencing proceedings in guilty plea cases. S. Schulhofer, Is Plea Bargaining Inevitable? 55-60 (April 14, 1983) (unpublished manuscript on file with The University of Chicago Law Review; forthcoming in 97 Harv. L. Rzv. - (Mar. 1984)).

ss The Prosecutor's Role, supra note 4, at 56.

st Id. at 104. 
process often has led to vacant courtrooms as defendants, for both strategic and psychological reasons, have delayed their acceptance of prosecutorial offers until shortly before their cases were scheduled to be tried. It has led, in addition, to frequent court recesses for the purpose of facilitating negotiations. Finally, plea negotiations themselves may be prolonged, may be characterized by banter and psychological ploys, and may consume substantial resources. ${ }^{\text {s5 }}$

With all of its rituals and delays, the bargaining process is no masterpiece of efficiency. A recent study of the effects of Alaska's plea bargaining prohibition reported a thirty-seven percent increase in the number of trials and, at the same time, a substantial decrease in the time between the filing of felony charges and their final disposition. ${ }^{\text {s6 }}$ Although in Anchorage this change might have been attributable in part to personnel changes and to a new calendaring system, similar phenomena were observed in Fairbanks and Juneau. The study concluded that this reduced delay in the disposition of cases might be explained primarily by a reduction in the dilatory tactics that plea bargaining had encouraged..$^{57}$

In seeking the resources needed to implement the right to jury trial, one might begin with the substantial resources now devoted to plea bargaining gamesmanship. Still, even if Chief Justice Burger's estimates are discounted substantially, the high rate of guilty pleas in America may make the prospect of affording jury trials to all defendants who want them seem almost unthinkable. ${ }^{.8}$

This prospect becomes less unthinkable, however, when one recognizes how limited the current resources are. In my home jurisdiction, Boulder County, Colorado, with a population of 190,000 , a single judge conducts all trials, hearings on motions, and guilty plea proceedings in felony cases. ${ }^{59}$ In nearby Denver, with a popu-

ss The Trial Judge's Role, supra note 4, at 1132 n.237.

so M. Rubinstein, S. Clarke \& T. White, Alaska Bans Plea Bargaining 151, 274 (Table II-2) (1980).

${ }^{\mathrm{sz}}$ Id. at 105-06.

bs Nevertheless, Professor Stephen J. Schulhofer has argued that if nonjury trials were afforded to defendants who now plead guilty, a reduction of the guilty plea rate from 90 to $80 \%$ would not require anything close to a doubling of current resources. Instead, this apparently dramatic change might require less than a $2.8 \%$ increase in judicial capacity. $S$. Schulhofer, supra note 52, at 157-159B.

s9 Bureau of the Census, U.S. Dep't of Commerce, State and Metropolitan Area DATA BoOK 1982, at 68 (1982) (189,625 people). The statistics given in this paragraph for the number of judges serving these various areas were obtained through telephone calls to court personnel in 1981. 
lation of approximately one-half million, ${ }^{60}$ five judges are responsible for the conduct of felony proceedings. The city of San Francisco, California, has just over two-thirds of a million people, ${ }^{81}$ but four judges in San Francisco hear felony cases on a full-time basis while two others hear felony cases part-time. In 1981, Indianapolis, Indiana, with almost three-quarters of a million people, ${ }^{62}$ had only two judges hearing felony cases.

A doubling, a tripling, or even a quadrupling of the resources now devoted to felony prosecutions therefore might require one, two, or three additional judges in counties like Boulder; two, four, or six additional judges in a city like Indianapolis; and five, ten, or fifteen additional judges in cities like Denver and San Francisco. Even when the necessary additions in physical plant, support personnel, jurors, prosecutors, and defense attorneys are considered, this sort of investment need not inspire panic. ${ }^{63}$ Indeed, in almost every American jurisdiction, a multiplication several times over of the resources devoted to the resolution of felony cases apparently would require no more than the building and staffing of one new courthouse. This task might be about as burdensome as the building and staffing of a new high school; it would be less burdensome than providing a new hospital. If the need were in medicine or education, however, responsible citizens would at least talk about meeting it. They would not insist that "practical necessity" required bargaining with patients to waive their operations or with students to waive their classes.

Although the current era is marked by taxpayer rebellion and a retrenchment in government services, Americans are seriously concerned about crime. ${ }^{64}$ They are so concerned that an over-

so Bureau of the Census, U.S. Dep't of Commrrce, Statistical Abstract of the UnITED STATES 21 (Table 24) (102d ed. 1981) (491,000 people).

1 Id. (679,000 people).

62 Id.

os Whether sufficient legal manpower is available to implement a plea bargaining prohibition is obviously a different question from whether sufficient funds are available. Nevertheless, at a time when law school enrollments have grown more substantially than the demand for legal services, so that many qualified law school graduates are unable to secure employment as lawyers, any manpower concerns that a plea bargaining prohibition might raise seem surmountable. Moreover, a nation that uses lawyers in welfare termination hearings and many other nontraditional settings, see, e.g., Goldberg v. Kelly, 397 U.S. 254, 27071 (1970), should be able to find enough lawyers to perform the more basic legal functions of prosecuting and defending criminal cases.

- See, e.g., Bureau of Justice Statistics, U.S. Dep'T of Justice, Sourcebook of Criminal Justice Statistics-1980, at 178 (Table 2.14) (1981) (92\% of the respondents to a Harris survey taken in 1978 regarded controlling crime as "very important in making the quality of life better in this country"-a greater proportion than regarded "achieving quali- 
whelming majority of the respondents in one Gallup poll reported that they would support increased expenditures to deal with this problem..$^{65}$ Nevertheless, Americans now spend approximately $\$ 13$ billion each year for police protection, more than four times as much as they spend for judicial services in both civil and criminal cases. $^{68} \mathrm{~A}$ relatively slight reallocation of today's crime-fighting dollars or a slight overall increase in the total crime-fighting budget probably would be sufficient to implement the right to jury trial in felony cases. Indeed, the necessary expenditure might prove cost effective even if judged solely in economic terms. One econometrician has estimated that each additional dollar expended on the criminal courts would reduce the current costs of crime by somewhere between five and eleven dollars. ${ }^{67} \mathrm{He}$ has suggested that an optimal American criminal court system, judged only in terms of its crime reduction efficiency, would be triple its current size. ${ }^{68}$ One need not have great faith in this analysis to recognize at least the possibility that greater expenditures on the criminal courts could be offset to some extent by resulting gains in crime control. ${ }^{68}$

It might be instructive to estimate roughly the costs of abolishing plea negotiation in felony cases throughout America. One significant difficulty in calculating this estimate, however, is that the effect of a plea bargaining prohibition on guilty plea rates is

ty education for children," "conserving energy," or any of the other items included in the survey with the same level of concern).

is See Justice on Trial-A Special Report, Newsweek, Mar. 8, 1971, at 16, 43 (Gallup poll "found fully $83 \%$ of Americans reconciled to the notion of putting more money into the [crime] problem").

os Bureau of Justice Statistics, supra note 64, at 4, (Table 1.3) (in 1979, federal, state, and local governments spent $\$ 13.1$ billion on police protection and $\$ 3.1$ billion for judicial services in civil and criminal cases).

67 E. Noam, A Cost-Benefit Model of Criminal Courts 11 (Rev. ed. July 1980) (unpublished manuscript on file with The University of Chicago Law Review) [hereinafter cited as Cost-Benefit Model]. See also E. Noam, The Criminal Justice System: An Economic Analysis of Benefits and Interrelationships (1975) (unpublished Ph.D. thesis in the Department of Economics, Harvard University) [hereinafter cited as Economic Analysis].

${ }^{68}$ Economic Analysis, supra note 67, at 7. The same scholar has estimated that every additional dollar expended on the police would reduce the costs of crime by only about 33c. Id. at 69.

69 Although I have written that "a substantial influx of resources" might lead to more severe sentences, The Changing Debate, supra note 4, at 725, I doubt that either the imprecise relationship between expenditure levels and sentence severity or the equally imprecise relationship between sentence severity and crime control can be approximated even remotely by an econometric formula. At the same time, a plea bargaining prohibition ultimately might enhance the effectiveness of the criminal sanction quite apart from any effect that this prohibition might have on sentencing. See id. at 706-07. 
almost entirely a matter of conjecture. In some jurisdictions where plea bargaining has been prohibited, guilty pleas still account for a high percentage of felony convictions. One federal district judge who does not permit plea agreements in his court has reported that he cannot discern any notable disparity in guilty plea rates between his court and others. ${ }^{70}$ In Alaska, where guilty pleas accounted for ninety-one percent of all felony convictions in the year before a plea bargaining prohibition, the rate declined to eightyfour percent in the year after. ${ }^{71}$ Of course, when a reasonably high guilty plea rate of this sort persists despite an announced prohibition of plea bargaining, one may suspect that some form of explicit or implicit bargaining, or at least a general perception on the part of defendants and their attorneys that judges may reward guilty pleas in the sentencing process, continues to exert an influence. ${ }^{72}$

If today's plea bargaining process is not a sham, an effective plea bargaining prohibition certainly ought to lead to more trials. At the same time, however, the claim that almost every defendant would insist on a trial in the absence of plea negotiation is unwarranted. Because juries are unpredictable and prosecutors may make errors, it sometimes is suggested that any defendant ought to seek a trial unless he receives some concession for foregoing it. ${ }^{73}$ Nevertheless, the chance that all state witnesses will suffer heart attacks on their way to the courthouse is not, in practice, a sufficient reason for most defendants and defense attorneys to insist on trial; and in many cases, the possibility of multiple heart attacks is apparently the best hope that defendants may have. ${ }^{74}$

Following a judicially initiated prohibition of plea negotiation in El Paso, Texas, I interviewed a number of prosecutors, defense attorneys, probation officers, and trial judges in that city. At the

70 United States v. Griffin, 462 F. Supp. 928, 932 (E.D. Ark. 1978) (Eisele, C.J.).

71 M. Rubinstein, S. Clarke \& T. White, supra note 56, at 118 (percentages derived from figure 2).

72 Alaska's plea bargaining prohibition, which was instituted by the state's Attorney General, obviously did not restrict the ability of trial judges to sentence defendants who were convicted at trial more severely than comparable defendants who had pleaded guilty. An evaluation of the Alaska reform found evidence of this implicit bargaining in some crime categories but not in others. Id. at 88 .

73 See, e.g., id. at 80.

74 As Professor Malvina Halberstam has observed, "While it is true that a defendant would have little to lose by going to trial, the typical criminal defendant would also have little to gain." Halberstam, supra note 17, at 36 (footnotes omitted); see M. HeumanN, supra note 35, at 60 (experienced defense attorneys agree that most cases are "devoid of any legally disputable issue" and that they are "born dead"). But see S. Schulhofer, supra note 52 , at 148-50 (only 39 to $52 \%$ of the cases in a Philadelphia sample could be regarded as "dead bang" cases"). 
conclusion of these interviews, I was persuaded that prosecutorial bargaining had been effectively abolished; not one of my sources hinted that there was a back door to the district attorney's office or a system of winks and nods that might achieve the effects of bargaining. More importantly, even though I was not convinced that implicit judicial bargaining had been eliminated, most defense attorneys were convinced; they insisted that El Paso's judges would not sentence defendants more severely after convictions at trial than they would following pleas of guilty. ${ }^{75} \mathrm{I}$ therefore asked these attorneys why they advised some clients to plead guilty, sometimes suggesting to them that it might be a denial of effective representation not to take whatever chance of acquittal a trial might offer. A common response was that in many cases the evidence is so overwhelming that it is simply hopeless to take the case to trial. ${ }^{78}$

Apart from the fact that defendants and their attorneys have little reason to seek trials that offer no realistic hope of acquittal, ${ }^{77}$ trial would not become an entirely cost-free alternative for defendants even in the absence of plea bargaining. Nonindigent defendants would continue to pay attorneys' fees and other costs, and even indigent defendants would invest the time and energy and suffer the delay, the uncertainty, and the psychological anguish that trials inherently require. The "process costs" of trial might lead to significant numbers of guilty pleas. ${ }^{78}$

Although some defendants would plead guilty without the in-

75 The judges themselves were unwilling to adopt this position without significant qualifications. One judge, for example, said that a defendant who insisted on trial when he had no plausible defense ought to receive a more severe sentence than if he had pleaded guilty. Interview with Judge Sam W. Callan, in El Paso (June 8, 1976).

${ }^{76}$ One lawyer seemed to capture the pervasive common sense of most others when he said, "I had a client last week who was charged with escape, and he was still in the handcuffs when they arrested him two hours later. If I had known how to try that case, I guess I might have given it a shot."

El Paso's plea bargaining prohibition led within a few years to an increase in the backlog of criminal cases. The increased backlog, in turn, led El Paso's judges to replace their initial plan for eliminating plea bargaining with a strange regime of bargaining by probation officers. See Callan, An Experience in Justice Without Plea Negotiation, 13 LAw \& Soc'Y REv. 327, 346 app. (1979). Nevertheless, Judge Callan, the principal architect of both El Paso's plea bargaining prohibition and its replacement, maintained that the addition of a single judge to the El Paso bench would have made modification of the initial plan unnecessary. Interview with Judge Sam W. Callan, in French Lick, Indiana (June 14, 1978).

${ }^{77}$ Lawyers and judges in Alaska emphasized this circumstance in explaining the persistence of a seemingly high rate of guilty pleas after the state's prohibition of plea bargaining. As one judge expressed it, "Human nature doesn't want to engage in a fruitless act." $M$. Rubinstein, S. Clakke \& T. White, supra note 56, at 81.

${ }^{78}$ For further discussion of the significance of "process costs" in inducing pleas of guilty, see infra notes $105-27$ and accompanying text. 
ducements that today's plea bargaining process provides, one can only guess how many. The best way to approach the task of estimating the maximum possible cost of a plea bargaining prohibition therefore may be to assess the cost of providing jury trials to all felony defendants. Even this task is not easy. For one thing, despite recent federal efforts to develop criminal justice statistics and to study the operation of the criminal justice system, ${ }^{79}$ no one has a very good idea how many defendants are charged with felonies each year in state and federal courts. In 1967, the President's Commission on Law Enforcement and Administration of Justice estimated this number at $338,000 .^{80}$ If this figure had since increased at the same rate as the United States population, it would now be $376,000 .{ }^{81}$ If it had increased at the same rate as arrests reported to the Federal Bureau of Investigation, however, it would be much larger, 591,900. ${ }^{82}$ Although it may seem doubtful that the capacity of the courts has increased as rapidly as the number of arrests, this larger figure can serve as a ballpark estimate. ${ }^{83}$

75 See, e.g., BuREAu of Justice Statistics, supra note 64, passim.

so Task Force on the Admin. of Justice, President's Comm'n on Law Enforcement ANd Admin. of Justice, TASK Force REPort: The Courts 55 (1967) ("According to the only available estimate, there are approximately 314,000 felony defendants formally charged by the filing of an indictment or information each year in State courts, and about 24,000 felony defendants are prosecuted in Federal courts.").

81 The population of the United States was estimated at 197,864,000 in 1967 and at $223,239,000$ in 1980. See Bureau of the Census, supra note 60, at 21 (Table 24).

s2 In 1967, 5,422,526 arrests were reported to the F.B.I.; in 1979 there were 9,488,212. See Federal Bureau of Investigation, 1967 Uniform Crime Reports 116-17 (Table 23) (1968); Federal Bureau of Investigation, 1979 Uniform Crime Reports 188-89 (Table 25) (1980).

${ }^{8 s}$ In 1980 , when California had more than $10 \%$ of the entire United States population, 43,609 defendants were charged with felonies in that state's superior courts. CAL. DEP'T of Justice, Crime and Delinquency in California 1980, at 45 (Table 6) (1980). Projecting the filing rates of this most populous state to the rest of the nation might be likely to yield an overestimate rather than an underestimate of the number of felony prosecutions in trial courts of general jurisdiction, but even this projection would yield a substantially smaller number of felony cases than the figure suggested here.

Statewide felony filings for 32 jurisdictions are reported in Bureau of Justice StatisTICs, supra note 64 , at 408 (Table 5.14). The total for all of these jurisdictions was 580,857 in 1977. Nevertheless, some of these jurisdictions treated each criminal charge as a separate "filing." For example, if an accused armed robber had been charged with robbery, assault, larceny, and the unlawful possession of a firearm following a single holdup, four felony filings would have been recorded. Moreover, if the defendant had been accused of accosting and robbing a half-dozen victims, the number of filings might have grown to twenty-four.

Even the jurisdictions that seemed to count defendants rather than charges reported the "unit of count" as "the number of defendants on the information, indictment, or complaint." Id. Apparently, if separate indictments or informations had been filed for robbing each of six victims in a single transaction, six filings would have been recorded.

So long as all of the charges against a defendant could be resolved at a single trial, these 
One multiple-city study estimates that approximately onethird of the annual felony filings are dismissed prior to trial. ${ }^{84}$ There is no reason to suppose that this figure would be reduced if plea bargaining were prohibited. To the contrary, to the extent that a plea bargaining prohibition strained available resources, prosecutors probably would be even more selective both in the cases that they filed and in the cases that they pressed to completion. The number of filings therefore might decline and the number of dismissals increase. If, however, only one-third of the hypothesized 591,500 felony filings each year were dismissed, the remaining 394,333 cases would represent the approximate number of cases in which jury trials might be required. Moreover, in something like 47,320 of these cases, jury trials are afforded already. ${ }^{85}$ The number of additional jury trials that a plea bargaining prohibition might require in felony cases would be about 347,013 .

One study of felony prosecutions in thirteen diverse state court jurisdictions compared the costs of guilty plea cases with those of jury trials. It reported that the entry of a guilty plea resulted on the average in "court savings per case" of $\$ 1528$ and in "prosecutor savings per case" of $\$ 450 .^{88}$ Although the total savings reported per case (\$1978) did not include any reduction in the cost of defense services, the "defense savings" effected by a guilty plea certainly do not exceed the "prosecutor savings." If the "defense savings" per case are also assumed to be $\$ 450$, the total savings per

charges should be regarded as a single unit for the purpose of estimating the maximum number of trials that a plea bargaining prohibition might require. Accordingly, the aggregate data presented in the Sourcebook of Criminal Justice Statistics seem even less helpful than the outdated estimate of the number of defendants charged with felonies offered by the President's Commission on Law Enforcement and Administration of Justice in 1967.

s4 K. Brosi, supra note 49 , at 15 .

Bs This figure represents eight percent of the initial felony filings. See Y. KAMISAR, W. LaFave \& J. Israel, Modern Criminal Procedure 23 (5th ed. 1980) (10 to 15\% of felony cases filed are ultimately tried and 60 to $65 \%$ of these trials are jury trials; accordingly, between 6.0 and $9.8 \%$ of the felony cases filed are resolved by jury trial).

${ }^{88}$ See K. Brosi, supra note 49, at 47 (Table 7) (figures in text derived from average of figures for individual jurisdictions shown).

${ }^{87}$ One reason is that public defenders commonly are paid less than prosecutors. See Nat'l Legal Aid \& Defender Ass'n, The Other Face of Justice 67 (1973) (86\% of defender offices reported that the chief public defender is paid less than his counterpart in the local prosecutor's office; $63 \%$ reported that staff attorney salaries are lower than in the prosecutor's office). Of course, because nonindigent defendants are expected to hire their own attorneys, not all of the increased costs of defense services caused by a plea bargaining prohibition would be borne by the public. In addition, in view of the current fee-setting practices of private defense attorneys, it is doubtful that an increase in the time devoted to trials would lead to a proportional increase in legal fees. See The Defense Attorney's Role, supra note 4 , at $1199-1200$. 
case becomes $\$ 2428$.

This $\$ 2428$ figure is probably an overestimate of the total additional cost that might be incurred by affording a jury trial to a typical felony defendant who now pleads guilty. ${ }^{88} \mathrm{It}$ is based on the assumption that this defendant's trial would consume 24.2 hours of court processing time, a figure derived from a 1974 study of jury trials in California. ${ }^{89}$ California seems atypical, however; other, nationally based studies have concluded that jury trials are usually completed, not in more than three days, but in less than two.90 Moreover, even this smaller figure probably is not an appropriate guide, for any estimate based on the current costs of jury trials overlooks the fact that jury trials occur most frequently in time consuming cases involving serious charges rather than in more routine prosecutions. ${ }^{91}$ Most of the cases now resolved through plea bargaining probably would require fewer resources to try than most of the cases tried today. ${ }^{92}$

Of course some of the 347,013 cases in which jury trials might be required are currently resolved at nonjury trials. In these cases, the incremental expenditure necessary to afford jury trials would be less than the additional cost of affording jury trials in cases now resolved by guilty plea. ${ }^{93}$ If, however, one disregards this additional

os At the same time, this figure may not include all the costs that a plea bargaining prohibition would impose. Most notably, an increase in the frequency of trials probably would lead to an increase in the frequency of appeals. The estimate does not consider the financial impact of a plea bargaining prohibition upon appellate courts or upon the appellate work of prosecutor and defender offices, nor does it include any figure for an expansion of correctional facilities. I have argued elsewhere that a prohibition of plea bargaining could not be expected, in itself, to lead to any increase in sentence severity. The Changing Debate, supra note 4, at 724-30.

so See K. Brosi, supra note 49 , at 47.

oo See Y. Kamisar, W. LAFAve \& J. IsrakL, supra note 85, at 13 (4th ed. 1974); BIRD Engineering-Research Assoc., Inc., Criminal Justice Information Service, Jury System Operation Final Report 14-17 app. D (1974).

-1 See, e.g., H. Kalven \& H. Zised, The American Jury 20 (Table 2) (1966).

92 Indeed, if the trial of a routine burglary or simple street crime truly would require more than three days and cost approximately $\$ 2500$, that circumstance would illustrate the need for a radical simplification of the American trial process. A reduction in the cost of trials would make a prohibition of plea bargaining substantially less burdensome. See infra Parts III-B, III-C.

Although $\$ 2428$ is an estimate of the cost savings effected by a guilty plea rather than an estimate of the total cost of a jury trial, the estimate was based on the assumption that a guilty plea proceeding requires only $1 / 97$ th of the resources required for a jury trial. See K. Brost, supra note 49 , at 47 (15 minutes of court time for guilty plea as compared to 1452 minutes for jury trial). The total cost figure for a jury trial is therefore only slightly higher than the "cost savings" figure.

"3 There are probably about 39,100 nonjury trials in felony cases each year in the United States. See supra note 85 (4.6\% of the 591,500 felony cases initially filed; $4.6 \%$ 
cost reducing factor and simply multiplies the $\$ 2428$ "guilty plea savings" by 347,013 , it becomes apparent that the annual cost of providing three-day jury trials to every felony defendant who reaches the trial stage probably would not exceed $\$ 843$ million. The cost of providing two-day trials would be about $\$ 559$ million. The cost of providing one-day trials (which ought to be adequate to permit careful development of the factual circumstances surrounding most crimes and which would facilitate and encourage much more attention than most felony prosecutions currently receive) would be about $\$ 275$ million. ${ }^{94}$

Even the $\$ 843$ million figure represents only a little more than one-third of Lockheed's $\$ 2$ billion cost overrun on the C-5A aircraft; $^{85}$ it is less than the cost of a single Aegis cruiser; ${ }^{86}$ and it is also less than the amount that the now-disbanded Law Enforcement Assistance Administration once spent annually on improving state criminal justice. ${ }^{97}$ Overall, an additional $\$ 843$ million per year would represent a $3.2 \%$ increase in civil and criminal justice expenditures in the United States over the level in 1979.88 As a prestigious national study group concluded ten years ago, "[T]he basic problem is not financial; the cost of a model system of criminal justice is easily within the means of the American people."19 When one glances behind the plea of poverty that advocates of plea bargaining have used to justify this practice, one sees mostly the desire of the legal profession to rationalize the way things are.

\section{B. Toward an Unencumbered Right to Trial in Misdemeanor Prosecutions}

Although the abolition of plea bargaining certainly would not

represents the approximate difference between the percentage of felony cases tried and the percentage tried to a jury). For one estimate of the differing costs of jury trials, nonjury trials, and guilty plea proceedings, see supra note 50. Of course the incremental cost of providing jury trials in cases now resolved at nonjury trials would not be a cost of prohibiting plea bargaining.

of These estimates are based on the assumption that a guilty plea proceeding consumes only 15 minutes of court processing time (1/97th of the time required for a three-day jury trial).

9s See B. Rice, The C-5A Scandal, at xii \& passim (1971).

${ }^{96}$ Is America Strong Enough?, NEwSwEEK, Oct. 27, 1980, at 48, 55.

${ }_{87}$ The 1975 budget of the Law Enforcement Assistance Administration was $\$ 887,171,000$. U.S. Office of Management \& Budget, The Budget of the United States Government Fiscal Year 1977, at 253 (1977).

${ }^{98}$ See Bureau of Justice Statistics, supra note 64, at 6 (Table 1.4) (1982).

io Research \& Policy Comm., Comm. for Economic Dev., Reducing Crime and AssurING JUSTICE 16 (1972). 
require so radical a change, even the prospect of affording jury trials to all felony defendants in America ought not cause one to blanch. Felony prosecutions comprise only about ten percent of all criminal cases, however, ${ }^{100}$ and the prospect of affording jury trials to all misdemeanor defendants might well inspire fiscal terror. Of course, as a first step toward reform (or perhaps even as a final step), a legislature might prohibit plea bargaining only in felony cases. This ten percent solution would be a major reform, and prudence might suggest that its consequences should be evaluated before going further. Moreover, even as a final accommodation, this solution would accord with the generally accepted notion that less careful and less safeguarded procedures are appropriate when lesser sanctions are at issue. ${ }^{101}$

Nevertheless, the elimination of plea bargaining in misdemeanor cases probably would be easier and less costly than its elimination in felony cases. It might require no influx of resources whatever. Indeed, a reformed misdemeanor system in which full trials were afforded to all defendants who wanted them conceivably might cost less to administer than the current misdemeanor system. As a prelude to the development of these positions, it will be useful to examine some of the basic motivations that prompt criminal defendants to plead guilty. The general discussion that follows will set the stage for an argument that unobjectionable procedures could yield as large a number of guilty pleas in misdemeanor courts as plea bargaining yields in those courts today.

1. Reasons for Pleading Guilty: A Three-Part Typology. Criminal defendants may decline to contest the charges against them although they do not expect their guilty pleas to lead to more lenient sentences. This section argues that there are normative and doctrinal distinctions among three types of guilty pleas: "no dispute" guilty pleas, "process cost" guilty pleas, and "bargained" guilty pleas.

Some observers, however, apparently do not see much difference between plea negotiation and other governmental practices that can lead to pleas of guilty. In Brady v. United States, ${ }^{102}$ the Supreme Court considered whether the threat of execution, seem-

100 See M. Ferley, The Process is the Punishment, at xv, 5 (1979); TAsk Force on the Admin. of Justice, supra note 80, at 29.

101 See, e.g., Scott v. Illinois, 440 U.S. 367, 373 (1979) (constitutional right to counsel inapplicable when defendants not threatened with imprisonment); Baldwin v. New York, 399 U.S. 66, 73 (1970) (constitutional right to jury trial inapplicable to offenses punishable by six months' imprisonment or less).

102397 U.S. 742 (1970). 
ingly one of the most coercive threats in the government's arsenal, had rendered a guilty plea involuntary. Although the Court assumed for purposes of decision that the threat of a death sentence had prompted the defendant "to plead guilty and thus limit the penalty to life imprisonment," it said that this assumption merely identified the threat of capital punishment "as a 'but for' cause of his plea." 103 This circumstance did "not necessarily prove that the plea was coerced."104 The Court explained:

The State to some degree encourages pleas of guilty at every important step in the criminal process. For some people, their breach of a State's law is alone sufficient reason for surrendering themselves and accepting punishment. For others, apprehension and charge, both threatening acts by the Government, jar them into admitting their guilt. In still other cases, the post-indictment accumulation of evidence may convince the defendant and his counsel that a trial is not worth the agony and expense to the defendant and his family. All these pleas of guilty are valid in spite of the State's responsibility for some of the factors motivating the pleas . . . ${ }^{105}$

Nevertheless, there are differences in kind as well as in degree among the circumstances that the Court described.

At one extreme, a defendant may plead guilty because he is remorseful or, even if not remorseful, because he recognizes that he has no possible defense to the government's charge. A guilty plea in this situation does not reflect the consensual resolution of a criminal dispute, for there is no dispute between the defendant and the state concerning the defendant's guilt. Of course one might favor trial even in this situation on paternalistic grounds (the defendant might be mistaken) or on the ground that trials serve important symbolic functions; ${ }^{106}$ indeed, with a seeming abundance of caution, most European nations require the trial of serious charges even when defendants admit their guilt and do not desire trials. ${ }^{107}$ Nevertheless, most Americans probably would consider a requirement of trial in no-dispute situations artificial. They would insist

${ }^{103}$ Id. at $749-50$.

104 Id. at 750 .

${ }^{105}$ Id.

${ }^{108}$ See Arnold, The Criminal Trial as a Symbol of Public Morality, in Y. Kamisar, F. Inbau \& T. ARnold, Criminal Justice in Our Time 137, 143-44 (1965); Gifford, supra note 38, at 70-71; Kipnis, Plea Bargaining: A Critic's Rejoinder, 13 LAw \& Soc'y REv. 555, 55657 (1979).

${ }^{207}$ See H. Silving, Essays on Criminal Procedure 250, 255 (1964). 
that disputes should not be manufactured when they do not exist in fact and that defendants should not be forced to use adjudicative procedures when the defendants themselves see no reason for doing so.

Even when a defendant considers himself innocent and recognizes the existence of disputable issues, he may yield to conviction because trial would be bothersome or expensive. A familiar example is the case of a driver who fails to contest a traffic ticket because a court appearance would be more burdensome to him than the payment of a fine. Guilty pleas induced by the "process costs" that defendants would incur by contesting the charges against them sometimes may be as troublesome as guilty pleas induced by plea bargaining. One can imagine, for example, an extraordinarily elaborate procedure for the resolution of minor traffic disputes that would require every traffic defendant who sought a trial to spend the better part of a week in a courtroom. In practice, despite its formal safeguards, this procedure would not afford traffic defendants greater protection than they currently receive. Instead, it probably would prove as effective as any but the most virulent plea bargaining practices in inducing pleas of guilty. Procedural safeguards plainly have backfired when those whom they were intended to benefit find the procedures too burdensome to use. ${ }^{108}$

At the same time, significant process costs are inherent in any form of adjudication. When shaping our courtroom procedures, lawmakers ought to be aware of these costs and of the burdens that they are likely to impose, not only on the taxpayers who finance them, but on defendants as well. Still, after these burdens have been considered, certain procedures will of course be considered essential to fair adjudication. ${ }^{109}$ Although the costs imposed by these procedures inevitably will lead some defendants to decline to contest the charges against them, this result should not cause notable concern. So long as the adjudicative balance is fair and the procedures seem worthwhile, their chilling effect will be incidental. The purpose of these procedures will be the promotion of fair and

${ }^{108}$ In recent years, commentators have begun to devote some attention to the effects of process costs in inducing pleas of guilty. For example, one commentator has noted that defendants may plead guilty partly because trials would require them to pay substantial legal fees, and has proposed that acquitted defendants be reimbursed to a certain level for their legal expenses in order to minimize this "process cost" inducement to sacrifice the right to trial. Note, Costs and the Plea Bargaining Process: Reducing the Price of Justice to the Nonindigent Defendant, 89 YaLe L.J. 333 (1979).

100 These procedures are likely to vary with both the complexity of the issues presented and the severity of the sanctions threatened. 
accurate verdicts, not discouragement of the exercise of the right to trial. Any waiver of legal rights that these procedures induce will be an inevitable by-product of an appropriate adjudicative process, and a defendant who cares too little about his case to fight conviction through appropriate procedures probably should not be forced to do so. Like guilty pleas in no-dispute situations, guilty pleas induced by appropriate process costs seem unobjectionable.

Finally, a defendant may plead guilty, not because contesting the charges against him would be too much trouble, but because a judge or prosecutor has threatened to "up the ante" or to impose a more severe penalty if he exercises the right to trial. The threat of differential punishment, whether phrased in terms of rewarding a plea of guilty or of penalizing the exercise of the right to trial, is the essence of the plea bargaining process. ${ }^{110}$ This threat is not merely an incident of a procedure designed to promote fair and accurate verdicts; instead its very purpose is to discourage the exercise of a constitutional right. ${ }^{111}$ It is this gratuitous threat that opponents of plea bargaining find offensive and that an effective plea bargaining prohibition should eliminate.

Even if one assumes that the consensual resolution of most misdemeanor prosecutions is a practical necessity, one should not confound this apparent necessity with a need for plea bargaining. For it is primarily the process costs of misdemeanor justice that currently cause all but a small minority of defendants to yield to conviction; these process costs are, in practice, more influential than plea bargaining. Before proposing a simplified nontrial procedure for misdemeanor cases-one that would make plea bargaining in these cases even less necessary than it is today-this article will explore the impact of current process costs on the decisions of misdemeanor defendants to plead guilty.

2. The Process Costs of Misdemeanor Justice. The most insightful recent study of an American misdemeanor court is a book by Professor Malcolm Feeley, The Process Is the Punishment. ${ }^{112}$ This work, whose thesis is stated succinctly in its title, describes the functioning of the Court of Common Pleas in New Haven, Connecticut, a court with jurisdiction over misdemeanors and lesser felonies. In this reasonably typical lower court, although every defendant had a right to trial by jury, not a single defendant 
in a sample of 1640 cases invoked that right. ${ }^{113}$ The principal reason for the stunning lack of jury trials was not the practice of plea negotiation. Instead, according to Feeley's description, the routine workings of American misdemeanor justice yielded a troublesome conclusion-a conclusion expressed here in less cautious terms than Feeley himself expressed it. A misdemeanor defendant, even if innocent, usually is well advised to waive every available procedural protection (including the right to counsel) and to plead guilty at the earliest possible opportunity. ${ }^{114}$ This strategy is likely to minimize the painful consequences of criminal proceedings for the defendant even when he almost certainly would be acquitted at trial and even when he receives no sentencing concession in return for his plea.

In the Court of Common Pleas, an immediate guilty plea is typically followed by a suspended sentence or a small fine (usually of less than thirty dollars). ${ }^{116}$ Although the defendant incurs the disabilities of a misdemeanor conviction, for a variety of reasons a person who appears as a misdemeanor defendant is unlikely to regard these disabilities as a serious burden. ${ }^{116}$ The limited formal sanctions that follow a plea of guilty pale in practice when compared to the informal and largely unintended sanctions that flow routinely from an invocation of procedural protections.

When a misdemeanor defendant pleads not guilty, he may be unable to secure his pretrial release. A commonly noted irony of American misdemeanor justice is that, despite the widespread implementation of bail reform during the past two decades, many more defendants are imprisoned before trial than are imprisoned after conviction (four times as many in Feeley's sample, ${ }^{117}$ although the Connecticut bail reform statute has been widely regarded as a model). ${ }^{118}$ Moreover, when a defendant does not incur this most dramatic of the process costs that insistence on the right to trial may exact, a court may require him to post bond. To ob-

11 Id. at 9.

114 Cf. id. at 199-201.

113 Id. at 155.

116 For one thing, many defendants already have misdemeanor records. For another, a minor criminal record is not likely to limit the employment opportunities of day laborers or to cause the discharge of many people who already have jobs. Finally, Feeley observed that as a group misdemeanor defendants tend to be "present-oriented" and to discount the remote possible consequences of conviction. Even when they probably should take the collateral consequences of misdemeanor convictions seriously, they usually do not. See id. at 201 . 117 Id. at 236.

118 See, e.g., O'Rourke \& Carter, Comment: The Connecticut Bail Commission, 79 YalE L.J. 513, 514-15, 520, 526 (1970). 
tain his bond, the defendant ordinarily must locate a bondsman and pay a fee of $\$ 70$ or $\$ 100$, an amount greatly in excess of the fine that normally would follow conviction. ${ }^{119}$

Similarly, when a nonindigent defendant seeks the services of counsel, he is likely to pay a legal fee of about $\$ 350$, an amount more than ten times larger than the average fine. ${ }^{120}$ Even an indigent defendant entitled to free legal services may find the process of representation burdensome. Initially, the appointment of counsel may subject this defendant to minor indignities; an apparently irritated judge may ask, for example, why the defendant has not sold his car to hire a private attorney. ${ }^{121}$ Then the defendant's attorney insists on an interview at the public defender office. The appointment usually is scheduled at a time when an employed defendant otherwise would be at work; it may well be canceled and rescheduled; and when the time for the defendant's appointment does arrive, he is likely to be kept waiting. ${ }^{122}$ Finally, for several reasons (including the scheduling conflicts of attorneys), representation by counsel may increase significantly the number of court appearances that a defendant is required to make. Apart from its more obvious burdens, each appearance may lead to a loss of wages and may risk the defendant's dismissal from his employment. ${ }^{123}$ When a prosecutor in the Court of Common Pleas asks a defendant, "Do you want to get your own attorney, apply for a public defender, or get your case over with today?,"124 he accurately describes the defendant's dilemma. Half of the defendants in Feeley's sample did forgo the services of counsel. ${ }^{125}$

Feeley reported that when a court appearance is scheduled, every defendant is required to appear at 10:00 A.M., an hour early enough that it usually will have been impractical for the defendant to report to work but late enough that he already will have missed

119 M. Feeley, supra note 100, at 238 .

$120 \mathrm{Id}$.

121 Id. at $220-21$.

122 See id. at 32.

${ }^{123}$ See id.

224 Id. at 220.

${ }^{125}$ Id. at 9. A defendant eligible for a pretrial diversion program may be able to avoid conviction by participating in regularly scheduled meetings for a three-month period. If he declines to participate, however, his case is likely to be dismissed anyway. Moreover, if the defendant is convicted, he runs virtually no risk of incarceration and ordinarily pays only a $\$ 10$ or $\$ 20$ fine. It is not surprising that only $2.3 \%$ of the eligible defendants chose to participate in the court's diversion program. Id. at 233. Indeed, Feeley noted that, from a defendant's perspective, even a decision to engage in protracted plea negotiation is likely to increase the practical burdens of the criminal process. Id. at 30. 
a significant part of the working day. And when the court convenes, the defendant usually waits. Many cases are not called until after the court's noon recess, and after the defendant has waited, he may be informed that his case will be continued and heard another day. If one assumes, based on Feeley's findings, that a court appearance typically requires four hours of a defendant's time and that the average number of appearances per defendant is 3.3 , a defendant who is paid only the minimum wage is likely to lose more in wages by virtue of his appearances than he ordinarily would have been required to pay in fines had he pleaded guilty at the earliest opportunity. ${ }^{128}$ Finally, when a case does go to trial, the defendant must incur the additional burden of locating witnesses and arranging their appearance and must suffer the anxiety and frequent humiliation that trial is likely to involve.

When misdemeanor defendants confront process costs that significantly exceed the sanctions at issue, plea negotiation plainly is unnecessary to induce the overwhelming majority to yield to conviction. Far from qualifying as a practical necessity, this practice becomes gratuitous overkill. As Feeley summarized his findings, "In essence, the process itself is the punishment. The time, effort, money, and opportunities lost as a direct result of being caught up in the system can quickly come to outweigh the penalty that issues from adjudication and sentence."127

Many of the process costs that Feeley described could be eliminated. Certainly a defendant should not be required to post a $\$ 1000$ bond in a case in which the sanction realistically at issue is a fine of $\$ 30$. It seems almost equally nonsensical to require all defendants to appear in court at the same early hour when most of their cases will not be called until substantially later. The scheduling of court proceedings on Saturday or in the evening might help minimize the burdens of criminal justice not only for defendants but for victims and witnesses as well. Nevertheless, even after a conscientious effort to minimize process costs, the problem would remain. When a defendant recognizes that the evidence against him is strong (and frequently even when it is not), very little process can overbalance the nonincarcerative sanctions at issue in most misdemeanor prosecutions. Even when the adjudicative process is expeditious, rational, self-interested defendants usually will "pay the man the thirty dollars and go home." With plea bargaining or without it, misdemeanor courts are unlikely to become the 
scene of frequent adversary battle.

3. A Simplified Nontrial Procedure for Misdemeanor Cases. Once this central reality of misdemeanor justice is recognized and its implications faced, the direction of reform seems plain. A simple, straightforward nontrial procedure should be made available to misdemeanor defendants who do not wish to contest the charges against them. This procedure would (1) eliminate some costs currently and unnecessarily imposed even on defendants who decline contest with the state, thereby making contest less likely; (2) reveal to defendants the limited sanctions realistically at issue in most misdemeanor prosecutions, thereby promoting intelligent decisions concerning the wisdom of incurring the costs of trial; (3) at the same time assure defendants that their sentences will be unaffected by the exercise of legal rights so that the burdens incurred by insisting on trials will be only those inherent in the adjudicative process itself; (4) bring substantially greater order and dignity to misdemeanor proceedings; and (5) conserve prosecutorial and judicial resources, which might be used to afford trials to defendants who want them. The penal order procedure of West Germany provides a useful model for this reform. ${ }^{\mathbf{1 2 8}}$

Under this West German procedure (comparable to the nontrial procedures employed by most other European nations in minor cases), ${ }^{129}$ a prosecutor may propose a specific penal sanction

128 The reluctance of some American observers to draw lessons from comparative study is so strong that one may hesitate to mention that a proposed reform has been implemented elsewhere. Even when one suggests that the proposal might be evaluated on its own terms without reference to an apparently successful foreign experience, a skeptic may dismiss it with observations about differing crime rates, legal traditions, cultures, and the like. For example, Professor Lloyd $\mathbf{L}$. Weinreb prefaced his proposals for substantial revision of the American criminal justice system by saying, " 'Continental' criminal procedure provided a direction for my thinking. . . . The reason for adopting a model like the one I have outlined, however, is not that something similar has worked acceptably elsewhere, but that that is where our own principles and experience lead." L. WEINREB, Denial of JUSTICE at x (1977). Nevertheless, Weinreb's critics generally failed to evaluate his proposals in the way that he suggested. Instead, they asserted a lack of empirical proof that Continental procedures truly work better than ours. See, e.g., Johnson, Book Review, 87 YALE L.J. 406, 410 (1977). It is conceivable that Weinreb's proposals would have had a more favorable reception if he had managed to keep secret their Continental origins, so that observations about the distinctive nature of our problems could not have been substituted so readily for an evaluation of the proposals' merits.

129 See, e.g., H. Suving, supra note 107, at 255 (Spain); Felstiner \& Drew, European Alternatives to Criminal Trials: What We Can Learn, Judges' J., Summer 1978, at 18, 2122 (Sweden, Denmark, and Belgium); Myhre, Conviction Without Trial in the United States and Norway: A Comparison, 5 Hous. L. Rev. 647, 649-51 (1968) (Norway); Pugh, Ruminations Re Reform of American Criminal Justice (Especially Our Guilty Plea System): Reflections Derived From a Study of the French System, 36 LA. L. REv. 947, 969 (1976) (France); Stepan, Possible Lessons From Continental Criminal Procedure, in The 
not involving imprisonment in a draft judicial order that courts routinely approve. ${ }^{130}$ The draft order informs the defendant that if he files an objection within a specified period of time, the order will be set aside and he will be entitled to a full criminal trial. If, however, he fails to object, the order will become final.

When a defendant accepts a proposed penal order, a parallel to the American guilty plea is of course obvious, and some similarity to plea bargaining is evident as well. Nevertheless, as Professor John H. Langbein has observed,

Two major aspects of penal order procedure distinguish it from American plea bargaining: the limitation to nonimprisonable misdemeanors and the absence of a sentencing differential. The former is explicit in the statute, and we need hardly belabor the contrast with American practice, where plea bargaining is routine for felonies and serious misdemeanors. ${ }^{131}$

As Langbein noted, a West German court is not precluded from imposing a more severe sentence after trial than the prosecutor had proposed before trial in a rejected penal order; the court, however, is inhibited from doing so by a requirement that any increase in a defendant's sentence beyond that proposed in a penal order be accompanied by a statement of reasons for this increase-reasons that apparently must be based on evidence that was unavailable when the penal order was proposed. ${ }^{132} \mathrm{~A}$ recent study by William L.F. Felstiner concluded on the basis of interviews with West German judges, prosecutors, and academics that "German defendants who do not accept a penal order . . . are not treated more harshly than those who do."13s Felstiner reported that prosecutors were strongly committed to the view that it would be unjust to penalize a defendant for rejecting a penal order (or, for that matter, for any other tactical mistake). This attitude was so pervasive that one prosecutor with eight years' experience told Felstiner incorrectly that a trial court simply lacked the authority to impose a more severe sentence than had been proposed in a re-

Economics or Crimg and Punishment 181, 198 (S. Rottenberg ed. 1973) (Austria).

${ }^{230}$ See Langbein, Land Without Plea Bargaining: How the Germans Do It, $78 \mathrm{MrcH}$. L. REv. 204, 213 (1979). For evidence that the judicial review of proposed penal orders is not always perfunctory, however, see Felstiner \& Drew, supra note 129, at 23.

131 Langbein, supra note 130, at 214.

238 Id.

12s Felstiner, Plea Contraqts in West Germaay, 13 LAw \& Sgc'y Rev. 309, 315 (1979). 
jected penal order. ${ }^{194}$

An American penal order procedure might be similar to West Germany's, but it should offer clearer assurances against an increase in sentence when a defendant exercises his right to trial. As in West Germany, a prosecutor who does not seek a defendant's incarceration ${ }^{135}$ should be able, if he chooses, to prepare a written proposal specifying whatever lesser sanction he considers appropriate. Before delivering this proposal to the defendant by registered mail, the prosecutor probably should be required to secure approval of its terms by a court. ${ }^{138}$ Of course the form of the proposal should emphasize its tentative character, ${ }^{137}$ yet it also should emphasize that if the defendant fails to object within a specified period of time, the proposed sanction will be imposed without further proceedings. If local law or practice extends the right to counsel to cases in which a defendant does not risk imprisonment, the proposal should advise the defendant of this right and of the procedure by which an indigent defendant may consult a public defender before accepting or rejecting the proposal. It also should contain a suitable admonition of the collateral consequences of a misdemeanor conviction. ${ }^{138}$. Upon objection by the defendant, he should

134 Id.

135 Even a defendant who risks incarceration may find it in his interest not to incur the process costs of trial when he recognizes that his chances of acquittal are small. A pretrial procedure that enabled this defendant to know the sanction at issue and to weigh this sanction against the burdens of trial would therefore have some virtue. Although extension of the penal order procedure to situations in which the state sought a defendant's imprisonment might not be seriously objectionable in any case and might in some cases be useful, any use of an essentially administrative procedure to deprive a person of his liberty remains somewhat troublesome. On balance, the focus of proceedings that may lead to incarceration probably should remain the courtroom, and judges should take a more active part in these proceedings than they are likely to take in the formulation of penal orders.

1s8 In West Germany, judges have tended to approve proposed penal orders without close scrutiny, see supra note 130 and accompanying text, and one suspects that judicial approval could become something of a rubber-stamp process in the United States as well. Nevertheless, when a defendant accepts a proposed penal order, the order determines his sentence. This article will suggest in addition, see infra note 139 and accompanying text, that the sanction proposed in a penal order should limit the sentence that a judge may impose following a trial. It therefore seems appropriate to give a court the opportunity to veto inappropriate proposals even if judges are unlikely to exercise this power very often.

137 For example, use of the word "order" probably should be avoided unless it is accompanied by a word like "tentative." The format of the West German penal order is probably too authoritative to serve as a close model for written prosecutorial proposals here. See $8 \mathrm{~K}$. Marquart, Handbuch Der Rechtspraxis 113-14 (3d ed. 1977).

${ }^{138}$ Whether obtained through a penal order procedure, through current plea negotiation practices, or even through adjudication, misdemeanor convictions are unlikely to reflect the careful deliberation that should accompany the imposition of lifetime disabilities. For this reason as well as others, it probably would be desirable to provide for the automatic expungement of misdemeanor convictions after a specified period of time. 
obtain a trial whose guilt-determination phase will be unaffected in any way by his rejection of the prosecutor's proposal.

If the defendant is convicted at trial, however, the proposal drafted by the prosecutor and approved by the court should as sume significance at sentencing. This proposal should advise the defendant that his insistence on trial cannot lead to a more severe sentence than the sanction that the prosecutor has proposed. In West Germany, defendants may be aware without this express assurance that courts virtually never "up the ante" when a defendant rejects a proposed penal order and insists upon trial, but in light of the pervasiveness of plea bargaining in the United States, the matter should not be left to implication here. ${ }^{130}$

Assurance that the post-trial sentence will not exceed the sentence proposed would free defendants of the gratuitous leverage of current plea bargaining practices. At the same time, specification of the sanction actually at issue would permit each defendant to choose between acquiescence and contest on a knowledgeable basis. With the stakes made clear, many defendants, especially those with little chance of acquittal, undoubtedly would forgo the burdens of trial. The procedure would in some ways be similar to plea bargaining, for prosecutors would continue to make sentence proposals on more or less the same basis that they do today. ${ }^{140}$ Nevertheless, each defendant's choice would be made on a more appropriate basis than that provided by today's bargaining practices-practices that usually leave the trial stakes unknown apart from the fact that they probably will include a tariff for the invocation of procedural protections. The factors influencing a defendant's choice would change significantly, but there is little rea-

139 Limitation of the post-trial sentence to the punishment specified in a pretrial proposal might seem incongruous in an unusual case in which the prosecutor had not investigated the circumstances adequately and in which evidence presented at trial showed the proposal to be too lenient. Nevertheless, the same sort of incongruity can arise when new evidence emerges after a plea bargain or a trial, and of course the overly lenient sentence would have gone undetected had the defendant simply accepted the prosecutor's proposal. In view of the offers that prosecutors commonly make in plea bargaining on the basis of incomplete information and their great effect on sentencing, a defender of plea negotiation probably should not insist too vigorously that sentencing always should be based on the fullest possible information. In any event, the incongruity of an occasionally inappropriate sentence would seem a small price to pay in order to assure defendants that their invocation of procedural safeguards will not be punished.

${ }^{140}$ In most cases, prosecutors probably would base their proposed penal orders on a review of police offense reports and the defendants' prior records, the same sources that they currently consult in formulating plea bargaining offers. See, e.g., M. HeumanN, supra note 35 , at 103. As in plea bargaining, however, prosecutors also would be free to interview witnesses or to consult other sources of information about their cases. 
son to expect the reform to increase significantly the number of trials.

Indeed, one important virtue of the proposed procedure is its efficiency. Despite the praise that today's plea bargaining process has received from champions of economy in government, this process is not efficient at all. Like misdemeanor trial procedures, plea negotiation procedures in misdemeanor cases impose substantial process costs-costs that to a considerable extent are unnecessary.

Today's misdemeanor defendants commonly must take time from work to assemble in crowded courtrooms. There they and their counsel wait for rushed huddles with a prosecutor or, frequently, with a prosecutor and a judge in chambers. The prosecutor or judge almost invariably offers some concession for a plea of guilty. When a defendant persists in seeking a trial, the prosecutor or judge may offer a greater concession. Then, when the bargaining is concluded, the judge ascends the bench, delivers some formal admonitions, and accepts pleas of guilty from almost all of the defendants in his court.

Certainly the admonitions that surround the acceptance of pleas of guilty would mean more if they. were presented to each defendant in writing and if he could consider them at leisure before deciding whether to accept a prosecutor's proposal. Similarly, a penal order procedure would save both defendants and prosecutors the need to make and evaluate proposals under the pressures of a "hurry-up" conference. The crowds, the waiting time, the absences from work, the cajolery, the general bustle; and the play of personalities would all be eliminated. The misdemeanor process would become far more dignified and deliberative. Moreover, although the detailed cost accounting necessary to document this proposition seems nearly impossible, a penal order procedure almost certainly would cost American taxpayers less than today's daily enactment of scenes from Kafka. The resulting savings could be used to provide trials in misdemeanor cases in which defendants did risk imprisonment and sensed a significant chance of acquittal and in other atypical cases in which defendants found the inherent costs of trial worth bearing. Conceivably, some savings might even be left over and used to finance trials in felony courts where, from the defendant's perspective, process costs usually do not loom so large. In any event, it would seem desirable to introduce to the criminal justice system a remarkable technological innovation, the post office. With the adoption of a nontrial procedure for misdemeanor cases vastly more orderly than today's lower court plea bargaining, the elimination of plea bargaining in misde- 
meanor courts probably would impose little or no additional burden on American taxpayers.

\section{The Problem of Enforcement}

Although some plea bargaining proponents contend that an attempt to prohibit this practice would "drive [it] . . . back into the shadows from which it has so recently emerged,"141 others apparently maintain only that complex, far-reaching mechanisms for enforcing the prohibition would be necessary. ${ }^{142}$ For example, when the Supreme Court upheld the constitutionality of plea bargaining in Brady v. United States, ${ }^{143}$ it wrote:

A contrary holding would require the States and Federal Government to forbid guilty pleas altogether, to provide a single invariable penalty for each crime defined by the statutes, or to place the sentencing function in a separate authority having no knowledge of the manner in which the conviction in each case was obtained. In any event, it would be necessary to forbid prosecutors and judges to accept guilty pleas to selected counts, to lesser included offenses, or to reduced charges. ${ }^{144}$

Anyone who seeks a plan for abolishing plea bargaining that would preclude all revision of criminal charges, forbid all guilty pleas, or seek in other ways to foreclose every conceivable route of evasion will not find it in this article. Indeed, plea bargaining probably cannot be abolished. Neither can murder, armed robbery, racial discrimination, police brutality, cruelty to animals, littering, or (probably) any other activity known to humankind. So far as I am aware, there is no perfect enforcement mechanism for any legal obligation.

Of course, the violation of a law can become so widespread that the law itself seems futile. Federal liquor prohibition offers the classic illustration. Nevertheless, some evasion is routinely tolerated-substantial evasion on occasion. For example, our legal restrictions on the sale of cigarettes to minors have not made it impossible for minors to obtain cigarettes. To a considerable extent,

161 The language is from Bordenkircher v. Hayes, 434 U.S. 357, 365 (1978). See also supra note 38 and accompanying text.

${ }^{142}$ Indeed, some opponents of plea bargaining apparently share the same view. For example, Parnas and Atkins have proposed an early "charge-setting hearing" at which a magistrate or judge would approve a charge that a prosecutor could not alter without presenting "significant new information" to the court. Parnas \& Atkins, supra note 47, at 119-21.

14s 397 U.S. 742 (1970).

146 Id. at 753 . 
these restrictions have invited subterfuge and have driven cigarette smoking by minors underground. Nevertheless, without these restrictions the number of minors who smoke probably would increase. ${ }^{145}$ Despite disturbing evasions, legal prohibitions that merely reduce the incidence of prohibited behavior can be worthwhile. It is a matter of costs and benefits and a matter of degree. It therefore is not enough for social scientists to proclaim that the opponents of plea bargaining are bound to fail if they wish to create a bargain-free world. ${ }^{148}$ That criticism implicitly applies to one law a standard that no law can meet. Similarly, an empirical finding that some plea bargaining persists in a jurisdiction that has purported to ban it is worth little more as a guide to policy than a finding that some burglary persists in a jurisdiction that has attempted to end that activity.

Of course prosecutors and defense attorneys sense personal advantages in plea bargaining. There are natural temptations to engage in most of the activities that the law prohibits. Moreover, plea bargaining commonly occurs in private where no victim, member of the public, or other watchdog is likely to see it and howl. Undeniably, the impediments to enforcement of a plea bargaining prohibition are substantial. Again, however, plea negotiation is not unique. Without suggesting that bribery is analogous to plea bargaining in more important ways, one can note a minor parallel. It is always in the interest of a person who offers a bribe to secure favorable governmental action, and it is always in the interest of an official who accepts a bribe to become rich. Bribery, too, is a transaction between willing adults in private. We have not concluded that the only realistic choice is to legalize bribery or else to drive it underground. ${ }^{147}$

In a few respects the enforcement of a plea bargaining prohibition might be easier than the enforcement of our laws against bribery, the sale of cigarettes to minors, and other forbidden consensual behavior. For one thing, the final product of successful plea bargaining-a plea of guilty - must surface in an inauspicious place for. illegal behavior, a courtroom. This circumstance at least can trigger an inquiry. For another, this official inquiry can be directed to prosecutors and defense attorneys, people who have special obligations to the law.

145 For a penetrating analysis of the problem of teenage smoking, see F. ZIMrING, THE Changing Legal World of Adolesscence 136-54 (1982).

14 See, e.g., M. Heumann, supra note 35, at 162.

147 See H. Packer, The Limits of the Criminal Sanction 267 (1968). 
A simple and straightforward plan for prohibiting plea bargaining might rely in part on these circumstances; it might consist of only a little more than what Anglo-American courts did long ago before they became so plea hungry. When a defendant submits a plea of guilty, the trial judge should question him, his lawyer, and the prosecutor individually, asking each whether any reward, favor, concession, or benefit of any description (express or implied) has been offered or is anticipated in response to the plea. ${ }^{148}$ Before accepting a guilty plea, a court should be required to find, as of old, that it is not motivated by hope of reward or by fear of official retaliation for exercising the right to trial. Moreover, although some observers have argued that implicit judicial bargaining (the practice of sentencing defendants who plead guilty less severely than those convicted at trial) would lead to the speedy downfall of any attempted plea bargaining prohibition, ${ }^{149}$ they have failed to consider the most apparent response to this evasion-the prohibition of implicit bargaining along with its more explicit counterparts. As was apparently the practice in England in the nineteenth century, ${ }^{150}$ a trial judge might inform a defendant who submits a plea of guilty that his plea will make no difference in the sentence that he will receive. ${ }^{151}$

148 This formulation or something close to it might be appropriate for prosecutors and defense attorneys, but simpler language might be more suitable for interrogating defendants: Has anyone made a deal with you concerning your guilty plea? So far as you know, has anyone made any deal with your attorney? Has anyone told you that you are likely to receive a lighter sentence because you are pleading guilty? Have you been told that you are likely to receive some other break? Although no one may have told you to expect a break, do you in fact expect to obtain a lighter sentence or some other break because you are pleading guilty? In your own words, why have you decided to plead guilty?

149 E.g., M. Heumann, supra note 35, at 158.

150 See 1 J. Archbold, Criminal Proceddure, Plaading and Evidence 334 (8th ed. 1877):

[A]s defendants often imagine that, by pleading guilty, they are likely to receive some favor from the court in the sentence. . . the judge very frequently undeceives them in that respect, and apprizes them that their pleading guilty will make no alteration whatsoever in their punishment. If, however, they still persist in their plea of guilty, it is then recorded by the clerk ....

161 This proposal raises the question whether a defendant's plea of guilty might be relevant to the sentence that he should receive on some occasions. The issue is discussed in The Changing Debate, supra note 4, at 661-69, and I repeat here only a small part of that discussion:

One can imagine, if one likes, that a defendant once pleaded guilty out of remorse and therefore received a relatively lenient sentence. A second defendant, however, after noting the sentence that the first defendant received, may have pleaded guilty, not because he was remorseful, but because he hoped to obtain the same favorable treatment. From the day of this first strategic guilty plea until the present, no one has been able to tell simply by examining a defendant's plea whether or not he was remorseful. 
Of course we have experienced empty guilty plea ceremonies before, and this proposal might appear to invoke only the failed historic safeguards that have let us slide to where we are. Before endorsing this objection, however, one should consider what it says about members of the legal profession. For the proposal is not to turn back the clock. It is not to ask form questions of a defendant who has been persuaded that the court's acceptance of a guilty plea will save him from the harsh sentence likely after a trial. It is to ask-as part of a seriously intended plea bargaining prohibition-questions of two lawyers.

The theory that plea bargaining is inevitable because prosecutors and defense attorneys would find ways to bargain even if bargaining were illegal is unattractive-as unattractive as the theory that plea bargaining is ineradicable because our nation cannot afford to implement the right to trial promised by the Constitution. This theory offers a dark view of the legal profession. It sees America's men and women of the law as lawless, and it proclaims without evidence, without hesitation, and even without blushing that large numbers of these people not only would break the law to achieve their goals, but also that they would lie about this violation..$^{162}$

In many ways, to be sure, lawyers and judges could be expected to resist a plea bargaining prohibition. Many would construe ambiguities, expand exceptions, seek loopholes, and bend imprecise language in order to continue their established ways. Indeed, a defense attorney who believed a plea agreement to be in a client's interest ought to consider it his ethical duty to stretch a plea bargaining prohibition to its limit. Once the scope of the prohibition were made clear, however, his ethical obligation would be to comply. Our law imposes a great many limits on what lawyers may do to advance their clients' interests, and most lawyers seem to respect these limits (especially when the restrictions are reasonably clear, as in the commands not to bribe judges and not to suborn perjury). The key to an effective plea bargaining prohibition

Id. at 662 .

Of course there may be guilty-plea cases in which remorse is evidenced by circumstances other than the defendant's plea of guilty, and in some of these cases, a failure to plead guilty might have called into question the inference of remorse that otherwise would have seemed warranted. One would not hesitate to grant the defenders of plea bargaining this inch were it not for the strong likelihood that they would take a mile. Id. at 662 n.29.

${ }^{262}$ Although my writings have not expressed a terribly exalted opinion of lawyers and judges, I do not share this dismal vision of our profession. 
probably lies less in proliferating intricate enforcement mechanisms than in clarifying the scope of the substantive prohibition. As I have argued elsewhere at greater length, ${ }^{183}$ it is not always easier to regulate a practice than to forbid it; that modern truism simply is not true. The effective implementation of an unambiguous plea bargaining prohibition probably would prove less difficult than the enforcement of elaborate regulatory schemes. ${ }^{154}$ The Panel on Sentencing Research of the National Academy of Sciences reviewed the available literature on the implementation of plea bargaining prohibitions and declared, "Prosecutors have refrained from proscribed forms of bargaining."15s

Some advocates of plea bargaining apparently take a different and somewhat schizophrenic view. While confidently asserting that a prohibition of plea bargaining would be unenforceable, they disregard problems of enforcement in advancing their own proposals for reform. ${ }^{156}$ For example, the Advisory Committee on the Federal Rules of Criminal Procedure declared in 1974, "We have previously recognized plea bargaining as an ineradicable fact. Failure to recognize it tends not to destroy it but to drive it underground."157 At the same time, the Committee added to the federal rules a provision that trial judges "shall not participate in [plea] discussions." 158 The Committee offered neither a procedure for enforcing this prohibition nor any discussion of the likelihood of evasion; presumably the Committee regarded it as unthinkable that judges would not comply. One is left to infer that prohibiting judicial plea bargaining tends not to drive, it underground but only to destroy it. ${ }^{159}$ Other defenders of plea bargaining have offered such reform proposals as, "Similarly situated defendants should be afforded

163 Stlberman Book Review, supra note 4, at 1036-38.

264 See id.

285 I Rrsearch on Skntrancing 28 (A. Blumstein, J. Cohen, S. Martin \& M. Tonry eds. 1983). The panel sometimes described this general compliance with plea bargaining prohibitions as "formal." It noted, for example, that in a county in which only charge bargaining by prosecutors was proscribed, sentence bargaining by trial judges took its place at least in part. Id. at 187. Of course lawyers and judges have not hesitated to exploit the loopholes that the prosecutors who have authored most current plea bargaining prohibitions have left by accident or design. Nevertheless, recent experience apparently offers no support for the view that lawyers would violate plea bargaining prohibitions once some obvious loopholes were closed and the scope of the lawyers' obligations made clear.

tso Silberman Book Review, supra note 4, at 1036-38 (discussing Silberman's proposals for improving the plea bargaining process).

167 FrD. R. CRIM. P. 11 advisory committee note.

1sa FED. R. CRIM. P. 11(e)(1).

18* But see The Trial Judge's Role, supra note 4, at 1151-52. 
equal plea agreement opportunities."160 These observers may believe that the general high-mindedness of prosecutors will be enough to effectuate reforms that they desire but that no enforcement machinery can implement reforms that they oppose.

Of course some lawyers and judges might disobey a plea bargaining prohibition. For example, after telling a defendant that his choice of plea would not affect his sentence, a trial judge might disregard this pledge and, through actions that spoke louder than his words, demonstrate the foolishness of the defendant's exercise of the right to trial. To a considerable extent, the plea acceptance procedures proposed in this article wager the right to trial on the proposition that most trial judges have not attained the high level of malevolence that this turnabout would require. ${ }^{161}$ Nevertheless, some check on the possibility that the proposed procedures would become hypocritical rituals in the hands of dishonest lawyers and judges might be warranted.

This check could be provided by permitting postconviction proceedings in which allegations of noncompliance with a plea bargaining prohibition could be heard and adjudicated. When a defendant who has pleaded guilty demonstrates by a preponderance of the evidence that his plea was the product either of a sub rosa promise or of a pattern of implicit bargaining, his conviction should be set aside. Similarly, when a defendant convicted at trial shows by a preponderance of the evidence that he was sentenced more severely as the result of exercising his right to trial, he should be entitled to reformation of his sentence. ${ }^{162}$

2603 Standards for Criminal Justice $\S 14-3.1(c)$ (2d ed. 1980); Or. Rev. Stat. § 135.405(4) (1977).

${ }^{161}$ Of course, without any deliberate turnabout, a trial judge might inadvertently impose upon a defendant convicted at trial a more severe sentence than the judge would have imposed following a plea of guilty. Nonetheless, I believe that a judge would have done enough when he had done the best that he could. A sentence differential so small that the judge himself could not perceive it would be unlikely to discourage exercise of the right to trial.

Even if the sentence differential were eliminated, defense attorneys might "con" their clients by advising them that guilty pleas probably would be rewarded. A defendant might become skeptical of his attorney's description of a judge's sentencing practices, however, when the judge himself assured the defendant in court that his practices were different. Moreover, an attorney who offered this advice would be ethically obliged to reveal its nature when asked in court whether he anticipated that the defendant's guilty plea would be rewarded. An attorney who regularly advised his clients in one way and answered the court's inquiries in another could not be confident that his misconduct would escape detection.

${ }^{162}$ As federal and state rules have required ever-more-elaborate courtroom guilty plea colloquies, the Supreme Court has expressed the hope that sufficiently intricate plea-acceptance procedures can foreclose all avenues of postconviction relief. See, e.g., McCarthy v. United States, 394 U.S. 459 (1969); Blackledge v. Allison, 431 U.S. 63 (1977). The Court 
A few other embellishments of a plea bargaining prohibition merit consideration. It would be inappropriate to forbid a prosecutor from reducing a charge that he had filed if new evidence made the initial charge appear unjustified, and it also might seem inappropriate to forbid charge reduction when further reflection convinced the prosecutor that his initial charge was inequitable. Moreover, it might seem undesirable to prohibit a defense attorney from urging the prosecutor to reconsider his charge. Of course a chargerevision process, especially one that included discussions between prosecutors and defense attorneys, could lead to implicit understandings, implicit misunderstandings, and expectations of reciprocity. To clarify the situation, it might be desirable to require a prosecutor to file with any downward revision of a charge an express assurance that no expectation of reciprocity existed and that the defendant might still stand trial on the revised charge. It also might be desirable to provide that no guilty plea to the reduced

apparently believes that guilty pleas can be packaged carefully enough that the prospect of post-conviction proceedings will disappear. This hope is misconceived. An attachment to finality in guilty plea cases is likely to prevent even moderate reform of the plea bargaining process.

Although this article has expressed considerable optimism about revised courtroom procedures that would include the interrogation of prosecutors and defense attorneys, the parties to an improper bargain have an undeniable interest in concealing it. The proposed pleaacceptance procedures might inhibit illicit bargaining by lawyers but would be unlikely to reveal whatever bargaining occurred despite the ban. Moreover, today's courtroom procedures-procedures that seek answers only from defendants-are far less likely to succeed.

If the villain of a melodrama were to place a gun at the hero's head and require him to sign, first, a deed conveying his farm and, second, a paper declaring that there was no gun at his head, the second paper would be worth no more than the first. Moreover, the second paper would not gain value with the addition of more elaborate clauses and more emphatic denials. Similarly, a defendant's affirmation of the voluntariness of his guilty plea at the time that he enters it adds almost nothing to the plea itself. This in-court affirmation is merely another piece of paper, and making the defendant's affirmation more detailed and elaborate cannot cure its inherent defects.

Plainly coercive threats are unlikely to be revealed so long as the consequence of revealing them will be the rejection of a guilty plea-and the consequence of rejecting the guilty plea, execution of the threats. A full presentation of coercive circumstances can be expected only after those circumstances have abated, and any effort to force "final" adjudication of the voluntariness of a defendant's guilty plea at the moment it escapes his lips is fundamentally misguided.

Plea agreements can be placed on the record, but perhaps only to the extent that courts decline to review very seriously the terms of these agreements. Once some sorts of plea agreements were denied judicial approval, a court could not be certain that agreements of this sort would be revealed. Of course this circumstance does not argue against recording plea agreements. The principal function served by recording them, however, is not to facilitate judicial review of the fairness of their terms. It is to prevent misunderstandings and contrived claims concerning the contents of these agreements, the same function served by statutory requirements that especially important private contracts be memorialized in writing. See, e.g., U.C.C § 2-201 (1978). 
charge could be entered for a period of perhaps thirty days so that a sub rosa understanding could not be implemented immediately. ${ }^{163}$ The incentives for entering an under-the-table plea agreement plainly would be reduced if one party ran a substantial risk that the other would fail to carry out this unverifiable bargain.

I repeat that none of the safeguards proposed here would be foolproof and that some evasion undoubtedly would occur, ${ }^{164}$ but whatever the level of subterfuge and evasion at the outset, it probably would diminish with time. Law typically works less through specific enforcement mechanisms than through its gradual influence upon attitudes. Fifty years ago, for example, police use of the third degree to secure confessions was apparently a widespread activity. ${ }^{105}$ We have not, in the interim, devised an effective means of policing what occurs in the backroom of a stationhouse. Nevertheless, the third degree does not seem to be nearly as significant a problem today. ${ }^{168}$ Even if determined prosecutors and defense attorneys were to devise an elaborate system to evade new legal restrictions on plea bargaining, the next generation of prosecutors and defense attorneys might have a different attitude.

I have argued elsewhere that critics of the fourth amendment exclusionary rule "have followed too closely Justice Holmes' advice to view the law from the perspective of a 'bad man' who wishes only to evade it." 167 From a "bad cop" perspective, it is easy to ridicule the supposed deterrent effect of the fourth amendment exclusionary rule. ${ }^{108}$ This perspective, however, has led critics of the rule to overlook what is probably one of the law's success stories. Police behavior has changed for the better in the generation since Mapp v. Ohio, ${ }^{169}$ and it has improved dramatically in the two gen-

${ }^{16 s}$ Use of this waiting period was suggested by Professors John C. Coffee Jr. and Michael Tonry.

104 Without attempting to treat this regrettable circumstance as a virtue, one can note that at least it would reduce the strain on existing resources that a plea bargaining prohibition might produce. One cannot logically contend both that a plea bargaining prohibition would be a dead letter and that it would swamp the courts. If the behavior of prosecutors, defense attorneys, and trial judges would not change overnight, the morning would not see a sudden devouring of the courts by the caseload monster.

${ }^{168}$ See Nat' Comm'n on Law Observance \& Enforcement, Report on Lawlessness IN LAW ENFORCEMENT 153 (1931).

${ }^{168}$ See Miranda v. Arizona, 384 U.S. 436, 445-49 (1966).

107 The Changing Debate, supra note 4 , at 713.

${ }^{168}$ See, e.g., Bivens v. Six Unknown Named Agents of Fed. Bureau of Narcotics, 403 U.S. 388, 415 (1971) (Burger, C.J., dissenting) (the hope that the exclusionary rule would "give meaning and teeth to the constitutional guarantees" was "hardly more than a wistful dream").

${ }^{169} 367$ U.S. 643 (1961). 
erations since the Wickersham Commission reported on the third degree $^{170}$ and the Supreme Court began excluding coerced confessions from evidence in state criminal proceedings. ${ }^{171}$ The causes of these changes obviously are complex, but the law probably has had an influence. The principal reason has not been that lawless and dishonest officers have greatly feared the discovery of their abuses and the courtroom exclusion of coerced confessions or illegally seized evidence. Rather it has been that essentially law-abiding officers have accepted (although slowly and reluctantly on some occasions) the guidance that the law has provided. People who confidently assert that a prohibition of plea bargaining would only drive it underground have fallen into the Holmesian trap and have been thinking about law enforcement in the wrong way. The "bad man of the law" does deserve careful attention, but the good person of the law merits notice as well.

\section{Alternative Shortcuts}

This article has suggested that full implementation of the right to jury trial would be costly only in felony cases and that, even in felony cases, the cost would be far from exorbitant. Nevertheless, however bearable this cost might seem, Americans might prove unwilling to pay it. ${ }^{172}$ Even this refusal to afford criminal defendants the kind of trial promised by the Constitution would not require the continuation of plea bargaining. In providing elaborate trials to a minority of defendants while pressing all others to abandon their right to trial, our nation allocates its existing resources about as sensibly as a nation that attempted to solve its transportation problem by giving Cadillacs to ten percent of the population while requiring everyone else to travel by foot. The central argument of this part of the article is that less would be more.

The article develops this theme partly by exploring the experiences of other times and places. Much of today's talk about economic necessity, immutable principles of organizational interaction, and the inevitability of plea bargaining seems strained when one glances beyond the boundaries of our own criminal justice system. Most of the world actually lives in what the proponents of plea bargaining tend to regard as fantasy land. ${ }^{123}$ Moreover, the

170 See Nat'l Comm'n on Law Observance \& Enforcembnt, supra note 165.

171 See Brown v. Mississippi, 297 U.S. 278 (1936).

${ }^{172}$ The available evidence suggests that Americans are not in fact so miserly. See supra note 65 and accompanying text.

173 See supra note 35 and accompanying text. 
Anglo-American legal system itself survived without plea bargaining throughout most of its history. ${ }^{174}$ Indeed, two American jurisdictions, Philadelphia and Pittsburgh, have avoided the overwhelming dependency on plea bargaining that characterizes most American cities by implementing systems of expedited nonjury trials. ${ }^{175}$ History, comparative legal study, and contemporary American experience thus support a thesis that I have advanced before and that this part of the article will develop more fully: "[T]he more formal and elaborate the trial process, the more likely it is that this process will be subverted through pressures for self-incrimination. The simpler and more straightforward the trial process, the more likely it is that the process will be used."176

Apart from offering empirical material in support of this thesis, part II will consider a number of ways in which our trial procedures might be simplified. The key to eliminating America's widespread subversion of the right to trial may lie in making trial a more workable, more affordable procedure.

\section{A. Other Times, Other Places}

1. Some Lessons of History. In 1979, I published a history of the guilty plea in Anglo-American law, ${ }^{177}$ and for present purposes, only a brief recapitulation of some of my conclusions seems necessary. For many centuries, Anglo-American courts did not encourage guilty pleas but actively discouraged them. ${ }^{178}$ Guilty pleas apparently accounted for a small minority of criminal convictions during the Middle Ages, ${ }^{170}$ the Renaissance, ${ }^{180}$ the American colonial period, ${ }^{181}$ and even the first part of the nineteenth century. ${ }^{182}$ As recently as the early twentieth century, moreover, our criminal justice system was not as dependent on the guilty plea as it has now become. For example, in 1908 and for several years thereafter, only about fifty percent of all convictions in the federal courts were obtained by guilty plea rather than trial. ${ }^{183}$ Moreover, when plea

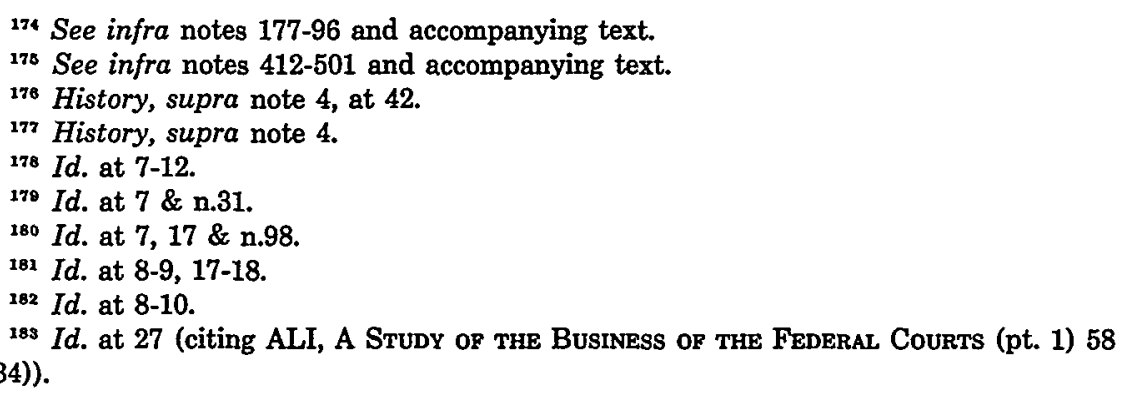


bargaining first emerged in the period following the American Civil War, appellate courts emphatically condemned it, and they articulated some principles that had seemed implicit in earlier practices on both sides of the Atlantic: "No sort of pressure can be permitted to bring the party to forego any right or advantage however slight. The law will not suffer the least weight to be put in the scale against him."184 "[L]itigation is . . . the safest test of justice."185 "The law . . . does not encourage confessions of guilt, either in or out of court."186 "All courts should so administer the law ... as to secure a hearing upon the merits if possible."187

In the golden age of trials that Anglo-American legal systems now have abandoned, the trials themselves were not gilt-edged..$^{188}$ When defendants offered to plead guilty, judges strongly urged them to reconsider, ${ }^{189}$ but this practice developed at a time when the trial process was neither notably burdensome nor particularly protective of defendants' rights. ${ }^{190}$ Professor Langbein has reported that an English jury could resolve between twelve and twenty cases during a single day in the 1730 's. ${ }^{191}$ At this time neither party was usually represented by counsel; there was ordinarily no voir dire of prospective jurors; a single jury might hear several cases before retiring; the accused participated actively and informally in the trial process; and the law of evidence was almost entirely undeveloped..$^{192}$ Moreover, Professor Lawrence M. Friedman has reported that one American felony court could conduct a half dozen jury trials in a single day as recently as the 1890 's. ${ }^{193}$

The speed and informality that characterized the trials of past centuries undoubtedly harbored potential for abuse, but the American jury trial now has become so complex that our society usually refuses to provide it. Reluctant to reconsider our expensive trial procedures, we press most defendants to forgo even the more expe-

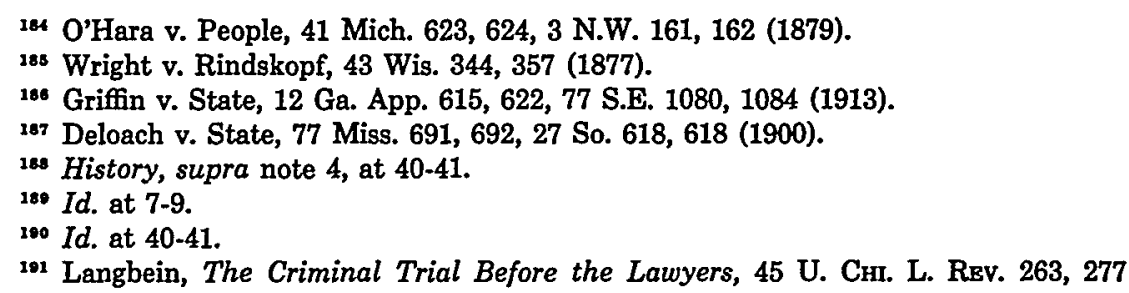
(1978).

${ }^{102}$ Id. passim; see also Baker, Criminal Courts and Procedure at Common Law, in Crime in ENGLand 1550-1800, at 15, 32-45 (J. Cockburn ed. 1977); Langbein, Shaping the Eighteenth-Century Criminal Trial: A View from the Ryder Sources, 50 U. CHr. L. REv. 1 (1983).

103 Friedman, Plea Bargaining in Historical Perspective, 13 LAw \& Soc'y REv. 247, 257 n.16 (1979). 
ditious form of trial that defendants once were freely afforded as a matter of right. ${ }^{194}$

As Professor Langbein has demonstrated, ${ }^{195}$ this paradox of our criminal justice system has a parallel in history. On the European continent during the late Middle Ages and the Renaissance, a formalistic, rule-bound trial process designed to protect defendants had proven unworkable in practice. Rather than revise their unrealistically high standards of proof, officials adopted expedient shortcuts to induce defendants to incriminate themselves. These shortcuts included a judicially sanctioned system of torture surrounded by supposed safeguards that were similar to those that surround the plea bargaining process today. ${ }^{196}$ Both Continental and Anglo-American history support the view that pressures for self-incrimination increase as trial procedures grow complex.

2. A Rapid International Tour. In 1961 in Rogers v. Richmond, ${ }^{197}$ the Supreme Court declared, "[O]urs is an accusatorial and not an inquisitorial system-a system in which the State must establish guilt by evidence independently and freely secured and may not by coercion prove its charge against an accused out of his own mouth."188 In this statement, the Court revealed some narrowness of vision. Professor Lloyd L. Weinreb has noted that "no country relies so much as we on the defendant's formal acknowledgement of his guilt." ${ }^{189}$ Plea bargaining is not only a relatively recent phenomenon; it is also a distinctive feature of Anglo-American legal systems. Still, as Professor Rudolph B. Schlesinger has observed with a touch of provocative exaggeration, "[W]hen it comes to problems of criminal procedure, [American lawyers] are possessed by a feeling of superiority that seems to grow in direct proportion to the ever-increasing weight of the accumulating evidence demonstrating the total failure of our system of criminal justice."200

That the extent of a jurisdiction's reliance on plea bargaining is likely to turn largely on the complexity of its trial procedures is illustrated, not only by America's unhappy experience and the less distressing experience of nations that have managed to avoid plea

\footnotetext{
104 See History, supra note 4 , at 41 .

${ }^{195}$ Langbein, Torture and Plea Bargaining, 46 U. Chr. L. Rev. 3 (1978).

108 See id. at 14-19.

107365 U.S. 534 (1961).

108 Id. at 541.

100 L. WEINREB, supra note 128 , at 148.

${ }^{200}$ Schlesinger, Comparative Criminal Procedure: A Plea for Utilizing Foreign Experience, 26 Bufralo L. Rev. 361, 363 (1977).
} 
bargaining, but also by the experience of some "intermediate" jurisdictions. Most notably, England's trial procedures have been used more frequently than our more elaborate alternatives but less frequently than the simpler procedures of nations that do not engage in plea bargaining. ${ }^{201}$ Moreover, the practices of other nations of the British Commonwealth and of countries like Israel that have derived their legal systems partly from English or American institutions seem to fit the same "in-between" pattern. ${ }^{202}$

The frequent denial that plea bargaining occurs in England ${ }^{20 s}$ is apparently based largely on semantics; ${ }^{204}$ there is ample evidence that what Americans would call plea bargaining does occur, not only in England, ${ }^{205}$ but also to some degree in several of these other nations. ${ }^{208}$ Nevertheless, these nations do not seem as dependent on plea bargaining as we are. ${ }^{207}$ The nation whose practice

201 See infra note 211 and accompanying text.

${ }^{203}$ See infra notes 203-16 and accompanying text.

${ }^{203}$ E.g., ABA House of Delegates Approves Fair Trial-Free Press Guidelines, 19 CRIM. L. REP. (BNA) 2437, 2440 (Aug. 25, 1976) (statement of Richard DuCann, Queen's Counsel).

204 For example, one prosecuting counsel in England told an interviewer, "There is a difference between plea-bargaining and accepting on behalf of the prosecution a plea to one of the counts, perhaps one of the lesser ones, in an indictment." Seifman, Plea-Bargaining in England, in Plea Bargaining 179, 188 (W. McDonald \& J. Cramer eds. 1980).

${ }^{208}$ See J. Baldwin \& M. McConville, Negotiatzd Justicz passim (1977); Baldwin \& McConville, Plea Bargaining and Plea Negotiation in England, 13 LAw \& Soc'y Rev. 287 (1979); Heberling, Conviction Without Trial, 2 ANglo-AM. L. REv. 428 (1973); Seifman, supra note 204; Thomas, An Exploration of Plea Bargaining, 1969 CRIM. L. REv. 69; cf. Davis, Sentences for Sale: $A$ New Look at Plea Bargaining in England and America (pts. 1 \& 2), 1971 CrIm. L. REv. 150, 218 (England and America have "very different plea bargaining practices"); Purves, That Plea-Bargaining Business: Some Conclusions from Research, 1971 CRIM. L. REv. 470 (concluding that plea bargaining in England "differs significantly [from that in America] at all levels").

208 See, e.g., B. Grosman, Thr Prosecutor 29-44 (1969) (Canada); Cousineau \& Verdun-Jones, Evaluating Research into Plea Bargaining in Canada and the United States: Pitfalls Facing the Policy Makers, 21 Canadian J. Crimmology 293 (1979); Parker, Copping a Plea, 20 ChiTTY's L.J. 310 (1972) (Canada); Ratushny, Plea-Bargaining and The Public, 20 ChrTTy's L.J. 238 (1972) (Canada); Verdun-Jones \& Cousineau, Cleansing the Augean Stables: A Critical Analysis of Recent Trends in the Plea Bargaining Debate in Canada, 17 Osgoode Hall L.J. 227 (1979); Westling, Plea-Bargaining: A Forecast for the Future, 7 Sydney L. REv. 424 (1976) (Australia); Interview with David Libai, former Israeli prosecutor and defense attorney, in Chicago (Oct. 11, 1967) (Israel); Letter from Robert D. Seifman, University of Melbourne (June 24, 1980) (Australia). For an indication that plea bargaining, if it occurs, lacks any official approval in New Zealand, see The King v. Walsh, 1948 N.Z.L.R. 937 (S.C.) (guilty plea set aside because Detective Sergeant might have induced defendant to plead guilty).

${ }^{207}$ For example, a former Los Angeles prosecutor who had become a Senior Lecturer in Law at the University of Sydney began a discussion of plea bargaining in Australia by saying, "There can be little doubt that some plea bargaining exists in Australian courts. It may not be very widespread, it may be done in subtle and unannounced ways, and it may lack official sanction, but it does exist in some degree." Westling, supra note 206, at 424. 
comes closest to that of the United States is probably Canada, where "of the cases adjudicated approximately 70 per cent are disposed of by guilty pleas and approximately 30 per cent ... by trial."208 Empirical studies of Canadian practices have concluded that the entry of a guilty plea has only a minor or imperceptible effect on a defendant's sentence-considerably less effect than this tactical decision usually has in the United States. ${ }^{209}$ Moreover, although plea bargaining may be reasonably widespread in Canada, most Canadian authorities seem far from reconciled to it. As two Canadian scholars have observed,

Evidently the plea agreement has now been enshrined as a cornerstone of the federal criminal justice system within the United States. In Canada, the main drift in policy making has been in exactly the opposite direction. Canadian courts are beginning to express strong disapproval of plea bargaining while the Law Reform Commissions both of Canada and Ontario have strongly advocated rigorous suppression of the practice. ${ }^{210}$

\section{In England, approximately forty percent of the defendants}

Although he knew of no official statistics, a former Israeli prosecutor and defense attorney expressed his confidence that guilty plea rates in Israel were substantially lower than those in the United States. He described plea bargaining in Israel as "neither very widespread nor very unusual." Noting the absence of jury trials, he observed,

There is no feeling that the great mass of defendants must be induced to plead guilty. Two or three ordinary trials, involving neither terribly simple nor terribly complex cases, can usually be conducted in a single morning. It is a rare case that cannot be proven with two or three witnesses, and prosecutors know that they may very well spend more time bargaining a case than they would spend at trial. Accordingly they do not regard plea bargaining as a great administrative boon.

Interview with David Libai, supra note 206.

${ }^{208}$ Ferguson, The Role of the Judge in Plea Bargaining, 15 CRIM. L.Q. 26, 30 (1972).

The statistics Ferguson cites are apparently derived from studies of Magistrates' Courts, and some studies of Magistrates' Courts have suggested lower guilty plea rates. See VerdunJones \& Cousineau, supra note 206, at 250-51 (43.5\% guilty plea rate in a sample of 1655 cases from the Magistrates' Courts of Toronto during 1970 and 1971). Guilty plea rates in the county courts and the Supreme Court are apparently lower than those in the Magistrates' Court. See Canadian Comm'n on Corrections, Toward Unity 134 (1969) (law enforcement officers believe $40.50 \%$ of all convictions result from guilty pleas). For a review of several studies of guilty plea rates in Canada, see Verdun-Jones \& Cousineau, supra note 206, at 250-51.

209 Compare M. Friedland, Detention Before Trial 121 n.12 (1965) (no great variations between the sentences imposed after guilty and not guilty pleas) and J. HoGaRTH, Sentencing as a Human Proczss 345-49 (1971) (no statistical correlation between plea and length of sentence imposed in Canadian Magistrates' Courts) with The Changing Debate, supra note 4, at 652-56 (empirical evidence indicates major effect of plea on sentence in the United States).

${ }^{210}$ Cousineau \& Verdun-Jones, supra note 206, at 294 and sources cited therein. 
charged in Crown Courts have received jury trials in recent years. ${ }^{211}$ Moreover, the plea bargaining that occurs seems relatively genteel by American standards. Until 1970, counsel for the defendant sometimes could obtain an advance indication from the trial judge of the sentence that his client was likely to receive on a plea of guilty, ${ }^{212}$ but a judicial decision of that year apparently put an end to the practice. ${ }^{213}$ Counsel for the crown is never permitted to make sentence recommendations, ${ }^{214}$ and bargaining focuses exclusively on possible reductions in the charge. Moreover, the Court of Criminal Appeal has ruled that it is improper to reduce a charge "where nothing appears on the depositions which can be said to reduce the crime from the more serious offense" and that trial judges should refuse to permit charge reductions unless this standard is satisfied. ${ }^{215}$ One commentator, a barrister familiar with both English and American practice, has maintained that concessions to defendants who plead guilty are far less routine in England, that judicial review of prosecutorial decisions is far more vigorous, and that American prosecutors "have assumed unto themselves certain discretions which in England are still carefully guarded by the judges." ${ }^{216}$

${ }^{211}$ Wilson, Crime and Punishment in England, PuB. InTerest, Spring 1976, at 3, 18. See also Baldwin \& McConville, supra note 205, at $287 \mathrm{n} .1$ (suggesting a somewhat lower figure for 1976); Heberling, supra note 205, at $428 \mathrm{n} .1$ (54\% of Crown Court convictions are by guilty plea). Guilty plea rates in the Magistrates' Courts seem considerably higher than those in the Crown Courts, however, id.; Baldwin \& McConville, supra note 205, at 287 n.1, and the rate of guilty pleas in England apparently has increased in recent decades. During the 1940's, it was asserted that less than half of those indicted in England pleaded guilty. L. Orfield, Criminal Procedure From Arrest to Appeal 297 n.122 (1947). To establish the legal context of these statistics, it should be noted that all trials in the Crown Courts are jury trials and all trials in the Magistrates' Courts are nonjury trials.

212 See, e.g., Stockdale, The Problem of Wounding With Intent, 1958 CRIM. L. Rev. 675,677 .

${ }^{213}$ Regina v. Turner, [1970] 2 Q.B. 321 (Crim. App.). This case held only that a judge could not indicate a probable sentence unless he also declared that this sentence would be unaffected by whether the defendant pleaded guilty or was convicted at trial. Nevertheless, the court's ruling led to a situation in which trial judges apparently never give advance indications of the sentences that they intend to impose. Interview with Ivan Lawrence, Member of Parliament and London barrister whose practice consists largely of defending criminal cases, in London (Sept. 1, 1980). At the same time, it is widely believed that English judges sentence defendants who plead guilty less severely than comparable defendants convicted at trial. One London solicitor maintained that a one-third discount is the approximate going rate. Interview with James Morton, in Boulder, Colorado (Apr. 6, 1983).

214 Interview with David S. Gandy, Chief Prosecuting Solicitor of the County of Greater Manchester, in Washington, D.C. (June 4, 1976); see Baldwin \& McConville, supra note 205, at 289 (a specific sentence recommendation by a prosecutor would be unethical).

215 Rex v. Soanes, 32 Crim. App. 136, 136-37 (C.A. 1948).

210 Davis, supra note 205, at 156; see also 1970 CRIM. L. REv. 601 (prosecutor's decision to proceed on reduced charges not binding on court). 
Although English trial and pretrial procedures are substantially more burdensome than those of many nations that sense no need to engage in plea bargaining, these procedures are also less elaborate than our own. The grand jury in England has been discarded, and nonunanimous jury verdicts are permitted. ${ }^{217}$ As is the case almost everywhere except in the United States, the products of unlawful searches and seizures are admitted into evidence in most cases. ${ }^{218}$ Although the law provides for the peremptory challenge of prospective jurors, this prerogative is rarely exercised, and a jury is usually empaneled in minutes. ${ }^{210}$ Of course English procedure recognizes a privilege against self-incrimination, but it also operates to encourage defendants to testify by forbidding impeachment on the basis of prior convictions in most situations and by permitting juries to draw adverse inferences from silence. ${ }^{220}$ These rules promote use of the evidence of defendants themselves-evidence that, as Professor Langbein has observed, is "almost always the most efficient testimonial resource."221 In addition, "lawyers almost never object to a question, ... . the hearsay rule has been abolished, . . . [and] leading questions are permitted on direct as well as cross-examination."222 The intermediate complexity of English trial procedure may explain both why plea bargaining has become part of the English criminal justice system and why it has not become as important a part of that system as it is of ours.

The criminal procedures of continental Europe have provided the principal model for most of the rest of the world, and although

${ }^{217}$ Edwards, English Criminal Procedure and the Scales of Justice, in The Economics of Crime and Punishment, supra note 129, at 203, 216-17; see also Kaufman, Criminal Procedure in England and the United States: Comparisons in Initiating Prosecutions, 49 Fordham L. REv. 26, 27 (1980) (elimination of grand jury).

218 Bivens v. Six Unknown Named Agents of Fed. Bureau of Narcotics, 4033 U.S. 388, 415 (1971) (Burger, C.J., dissenting); Jeffrey v. Black, [1978] 1 Q.B. 490 (Q.B. Div'l Ct.); Williams, The Exclusionary Rule Under Foreign Law-England, 52 J. Crim. L. CriminoLOGY \& Police ScI. 272 (1961).

210 See Zeisel \& Diamond, The Effect of Peremptory Challenges on Jury and Verdict: An Experiment in a Federal District Court, 30 StAN. L. Rev. 491, $498-99$ (1978); see also Stafford, Trial by Jury-the English Way, 66 A.B.A. J. 330, 332 (1980).

${ }^{220}$ See Schlesinger, supra note 200, at 378-79. An English judge may not invite a jury to infer that a defendant is guilty because he has remained silent, but a judge may invite a jury to give less weight to an account that a defendant has given for the first time at trial and to give special weight to prosecution evidence that the defendant has failed to answer. See Greenawalt, Perspectives on the Right to Silence, in Crime, Criminology and Public Policy 235, 240, 243-44 (R. Hood ed. 1974).

${ }^{221}$ Langbein, supra note 130 , at 208.

222 Stafford, supra note 219 , at 330. 
some Americans maintain that there are near equivalents of the negotiated plea in European practice, ${ }^{223}$ these Continental procedures also provide the principal illustration of the ability of advanced legal systems to avoid reliance on plea bargaining. ${ }^{224}$ The experience of the Scandinavian nations may be especially instructive, for in some ways the procedures of these nations differ from those on the rest of the Continent and are parallel to our own. Although writings in English about Scandinavian criminal procedure are unfortunately scanty, ${ }^{228}$ an article by Jonas A. Myhre, a Norwegian attorney, has provided a thoughtful description of the workings of criminal justice in that country. ${ }^{226}$ In most of continental Europe, even the institution of the guilty plea is unknown except in minor cases ${ }^{227}$ so that essentially the same trial procedures are employed when a defendant confesses as when he does not. Norway, however, does permit the consensual resolution of serious criminal charges.

For all offenses except those punishable by more than ten years' imprisonment, the Norwegian code of criminal procedure provides that a defendant may make "an unreserved confession" in open court. If the accuracy of this confession is "corroborated by other existing evidence," the code provides that "the case may, upon the consent of the accused, at once be adjudicated and tried without a formal charge and without lay judges being summoned."228 The resulting "trial" is probably somewhat more elaborate than the courtroom procedures that precede the acceptance of guilty pleas in the United States, but not greatly so. ${ }^{229}$ Moreover,

\footnotetext{
223 See, e.g., Goldstein \& Marcus, The Myth of Judicial Supervision in Three "Inquisitorial" Systems: France, Italy, and Germany, 87 YALE L.J. 240 (1977).

224 See, e.g., Damãska, The Realilty of Prosecutorial Discretion: Comments on a German Manuscript, 29 AM. J. Comp. L. 119, 130 (1980); Schlesinger, supra note 200, at 382; Weigend, Continental Cures for American Ailments: European Criminal Procedure as a Model for Law Reform, 2 Crime \& Just. 381, 386 (1980); Kötz, Book Review, 48 U. CHr. L. Rev. 478, 481 (1981).

225 See K. Haukaas, Norwegian Legal Publications in English, French and German 46-47 (1967). A useful description of Swedish criminal procedure is H. BECKER \& E. HJELLEMO, Justice IN MODERN SWEDEN (1976), which indicates the existence of a guilty plea procedure but offers no hint of plea bargaining. Id. at 87 .

126 Myhre, supra note 129.

${ }^{227}$ See H. Silving, supra note 107, at 250, 255.

228 Myhre, supra note 129, at 649-50.

129 See id. at 650,653 . In Japan, too, a procedure between a guilty plea and a full trial has been established-"a mode of summary trial which may be had when the accused, at the beginning of trial, has made a statement that he is guilty of the facts charged." Dando, Japanese Criminal Procedure Reform, in Essays in Criminal Science 447, 458 (G. Mueller ed. 1961). Nevertheless, one source insisted that there is no bargaining for guilty pleas or for judicial confessions in Japan. Interview with Chisugi Mukai, Tokyo trial judge, in Boulder,
} 
Norwegian prosecutors are not restricted by a rule of compulsory prosecution like the rules applicable in West Germany and Italy; they may properly decline to prosecute even when the evidence indicates a defendant's guilt. ${ }^{230}$

Norway also goes farther than most other European nations in promoting public participation in the administration of justice. Although this nation, like many others, employs mixed tribunals of professional and lay judges in less serious criminal cases, it retains ten-person criminal juries for the most serious cases. ${ }^{231}$ In addition, trial procedures are accusatorial in character, and the state bears the burden of proving the defendant guilty beyond a reasonable doubt. ${ }^{232}$ Finally, Norway, like most other European nations, has experienced a rapid expansion of criminal caseloads in recent years. ${ }^{233}$

Despite the existence of broad prosecutorial discretion, a confession procedure very much like the guilty plea, a jury system for serious cases, and other conditions that are thought to make plea bargaining inevitable in the United States, Myhre reported that the Norwegian prosecutor "is not allowed to bargain with the defendant in order to secure a conviction," that "he is liable to criminal prosecution if he does so," that "[b]argains are almost nonexistent," and that "the system functions very well without them."234

Of course, when prosecutors do not bargain, judges may reward the entry of guilty pleas by sentencing defendants who plead guilty less severely than those who are convicted at trial. ${ }^{235}$ This "implicit" judicial bargaining can prove as intimidating as the more "explicit" kind, ${ }^{236}$ and a system that merely substituted one

Colorado (Oct. 4, 1978).

230 Myhre, supra note 129, at 658-60.

232 Interview with Johannes Andenaes, Professor of Law and Director of the Institute of Criminology and Criminal Law at the University of Oslo, Norway, in Chicago (Mar. 14, 1968). The criminal jury also has been retained in Denmark and in some of the Swiss cantons. H. KaLven \& H. Zeisel, supra note 91 , at 14 n.3.

232 Myhre, supra note 129 , at 647.

233 Id. at 661 .

${ }^{234} I d$. at 658 . One rarely used Norwegian procedure, however, the patale unnlatelse, can be viewed as a form of plea bargaining. It is an official judgment of guilt rendered, not by a court, but by a prosecutor. It cannot be accompanied by any fine or imprisonment whatever. Although the issuance of a patale unnlatelse does not seem to be the product of back-and-forth negotiations, it must be accepted by the accused, and the accused does risk a more severe sanction if he rejects it and insists upon standing trial before a court. See Felstiner \& Drew, supra note 129 , at 21.

${ }^{235}$ See Church, Plea Bargains, Concessions, and the Courts: Analysis of a Quasi-Experiment, 10 LAw \& Soc'y Rev. 377, 384-88 (1976).

${ }^{238}$ See The Trial Judge's Role, supra note 4, at 1076-87. 
form of bargaining for another might not seem a promising model for reform. Myhre, however, addressed this possibility:

The punishment [of the defendant who confesses] will, neither as a matter of law, nor of practice, be more lenient than in judgments entered after a trial. The only concession thus given the accused is a procedural one, being saved the inconvenience and publicity of an ordinary trial. In spite of this, there are a great number of accused persons who prefer the summary adjudication, a fact which may sound rather incredible to those familiar with the system in the United States. $^{237}$

The ability of European legal systems to function effectively without plea bargaining seems to be disputed only in the United States, and the controversy focuses almost exclusively on the possibility of implicit bargains. European law forbids the exchange of prosecutorial or other official concessions for confessions, and despite the claim that those who find merit in the European systems may have compared the "law on the books" in Continental nations

2s7 Myhre, supra note 129, at 650. Nevertheless, of the Continental lawyers and scholars with whom $I$ have discussed the issue, the only one to concede the existence of a functional equivalent of plea bargaining in his nation spoke of a Scandinavian country. Professor $J \phi_{\mathrm{rn}}$ Vestergaard of the Institute of Criminal Law and Criminology of the University of Copenhagen, Denmark, noted that $64 \%$ of the defendants in cases filed by public prosecutors in Denmark in 1977 pleaded guilty, and he suggested that some form of implicit bargaining probably lay behind this figure. Although Professor Vestergaard doubted that lay judges have harsher attitudes toward sentencing than do professional judges, he observed that some professional judges and lawyers probably believe that lay judges are more severe. In Denmark, as in Norway, a defendant's confession usually leads to sentencing by a professional judge rather than by a mixed tribunal, and defendants with little chance of success at trial may confess partly because they prefer this alternative. Professor Vestergaard conceded that this speculation was based neither on experience, nor on observation of the criminal courts, nor on conversations with practitioners; he merely had drawn an inference from what he regarded as a high rate of confessions $-a$ rate that does seem higher than that of most other Continental jurisdictions. Interview with Professor Vestergaard, Institute of Criminal Law and Criminology of the Univ. of Copenhagen, Denmark, in Boulder, Colorado (Aug. 25, 1980).

Professor Johannes Andenaes of Norway was confident that in his country, too, a majority of defendants do not contest their guilt, but he rejected the suggestion that any sort of implicit bargaining might account for their confessions. It would be "impossible," Andenaes said, for a judge to declare that he viewed a defendant's failure to confess as an appropriate sentencing consideration, and a judge also would be unlikely to regard a defendant's confession as evidence of remorse except in the most unusual circumstances. $C f$. infra note 267 and accompanying text. According to Andenaes, Norwegian defendants feel no pressure to confess; the only benefits that a defendant may gain from confession are a simplified trial procedure and an escape from some publicity. Interview with Johannes Andenaes, supra note 231 . 
with the "law in action" here, ${ }^{238}$ European prosecutors, judges, and defense attorneys insist with a uniformity rarely encountered in field research that this legal requirement is observed and that talk of trading a defendant's confession for some benefit that a prosecutor or trial judge might provide simply does not occur. ${ }^{23 \theta}$

The legal constraints under which many European prosecutors operate. tend to add credibility to these assertions about prosecutorial practice. In West Germany, for example, a rule of compulsory prosecution applicable to serious offenses requires the prosecution of "all prosecutable offenses, to the extent that there is a sufficient factual basis."240 Violation of this rule can lead to citizen complaints and administrative and judicial remedies; in a meritocratic corps of career prosecutors in which even unsuccessful complaints may hinder career advancement, the incentives for obeying the rule are apparently powerful. ${ }^{241}$ Moreover, if a prosecutor were to defy the rule by charging a less serious offense than that which the evidence would support, his concession might prove ineffective; a West German court is not bound by a prosecutor's formulation of the charge and, after giving the defendant appropriate notice and an opportunity to be heard, may convict of any offense that the evidence establishes. ${ }^{242}$ Although West German prosecutors invariably make sentence recommendations, these recommendations are followed far less often than are prosecutorial sentence recommendations in the United States. ${ }^{243}$ In legal systems like West Germany's, in which the guilty plea as such does not 410.

${ }^{2 s 8}$ See, e.g., Goldstein \& Marcus, supra note 223, at 245; Johnson, supra note 128 , at

${ }^{239}$ See, e.g., Goldstein \& Marcus, supra note 223, at 269-70; Langbein, supra note 130, at 212 .

${ }^{240}$ Langbein, supra note 130 , at 210 . For discussion of the rule of compulsory prosecution, see generally Herrmann, The Rule of Compulsory Prosecution and the Scope of Prosecutorial Discretion in Germany, 41 U. CHI. L. Rev. 468 (1974); Langbein, Controlling Prosecutorial Discretion in Germany, 41 U. CHI. L. REv. 439 (1974).

${ }^{241}$ See Langbein, supra note 130, at 211.

242 See J. Langbein, Comparative Criminal Procedure: Germany 66 (1977); Weigend, supra note 224, at 402-03. Of course, in an effort to prevent the exercise of this judicial power, a West German prosecutor might attempt to keep incriminating evidence from the court, but this stratagem would also be difficult to effect. The court has the prosecutor's dossier before it and conducts most of the courtroom examination of witnesses. See J. LANGBEIN, supra, at 62, 74-75. Any facts that the prosecutor wished to suppress might very well be revealed.

${ }^{243}$ Compare Casper \& Zeisel, Lay Judges in the German Criminal Courts, 1 J. Legal STUD. 135, 167 n.31 (1972) (prosecutors' sentence recommendations adopted in $29 \%$ of the cases in a West German sample) with Johnson, Sentencing in the Criminal District Courts, 9 Hous. L. REv. 944, 971 (1972) (prosecutors' sentence recommendations adopted in $98 \%$ of the guilty plea cases in one Texas county). 
exist in serious cases, in which trials are so uncomplicated that there is little administrative reason to avoid them, and in which legal ideology strongly opposes any form of bargaining for confessions, even the most skeptical observers seem to agree that explicit plea bargaining is unknown. ${ }^{244}$

As Professor Langbein has contended, however, Americans "feel a deep need for reassurance that what they are doing is not so bad as it looks. . . . As a corollary to the proposition that plea bargaining is not really so bad, the claim is advanced that everybody else does it too." ${ }^{\text {245 }}$ Professor William M. Landes once wrote:

Although American and Continental procedures for disposing of criminal cases appear to be different . . . one can argue that in actuality they are nearly equivalent. . . . There does not have to be an explicit bargain between the prosecutor and the defendant. It is sufficient that the courts operate in a manner to reward defendants who have confessed with lighter sentences, and that this fact be known to defendants. We would predict that European trials in which a confession has been made . . . would be similar to the formal proceedings before a judge in the United States for defendants who plead guilty. If my hypothesis is correct, then confessions in European criminal procedure serve the same purpose as guilty pleas in American procedure. . . . This is not surprising since the forces I cited as producing guilty pleas . . . would operate on the Continent to produce confessions. ${ }^{246}$

Professor Landes, conceding a lack of empirical support for his hypothesis, recognized that it ought to be tested. ${ }^{247}$ Two American legal scholars, however, Abraham S. Goldstein and Martin Marcus, have reported on the basis of interviews in West Germany, Italy, and France that covert European practices may provide "functional analogues of the guilty plea and 'plea bargaining." "248

Goldstein and Marcus suggested that uncontested trials in Eu-

244 See Goldstein \& Marcus, Comment on Continental Criminal Procedure, 87 YalE L.J. 1570, 1571 (1978); Goldstein \& Marcus, supra note 223, at 269; see also McDonald, From Plea Negotiation to Coercive Justice: Notes on the Respecification of a Concept, 13 LAw \& Soc'y Rev. 385 (1979).

248 Langbein, supra note 130, at 204.

26s Landes, Comments on the Papers in the Seminar, in The Economics of Crime and Punishment, supra note 129, at 225, 228. Accord McDonald, supra note 244, at 386.

347 Landes, supra note 246, at 229.

2* Goldstein \& Marcus, supra note 223, at 264. For a forceful response to this article, see Langbein \& Weinreb, Continental Criminal Procedure: "Myth" and Reality, 87 Yals L.J. 1549, 1569 (1978). See also the rejoinder, Goldstein \& Marcus, supra note 244. 
rope were similar to guilty pleas in the United States, noting that European trials are likely to be relatively short when defendants admit their guilt. ${ }^{249}$ In fact, however, confessions shorten European judicial proceedings surprisingly little. In what was then the only empirical study of this question, Gerhard Casper and Hans Zeisel reported in 1972 that in West Germany a full confession normally cut the time devoted to trial in half and the time devoted to deliberation hardly at all. ${ }^{250}$ In a jurisdiction in which " $[t]$ he average ... duration of a [lesser court] trial is one-third of a day . . . [and] of a [major court] trial one day,"251 the time savings effected by a defendant's confession were not especially great. ${ }^{252}$ Moreover, a more recent study of lower court trials in West Germany reported that a defendant's confession merely reduced the average time of trial from seventy to fifty minutes. ${ }^{253}$ Although Goldstein and Marcus did present some evidence of the mass processing of criminal cases in lower courts in France, ${ }^{254}$ their conclusion that the uncontested trial in Europe is analogous to the American guilty plea seemed somewhat strained; and of course an even closer analogy would not have indicated in any way that uncontested trials in Europe are the product of a bargaining process. ${ }^{255}$

When Goldstein and Marcus turned from analogues of the guilty plea to analogues of plea bargaining, they focused primarily on whether the rules of compulsory prosecution applicable in Italy and West Germany and the assertedly comparable practice in France truly preclude the exercise of discretion by prosecutors and police officers. They found to no one's surprise that discretion had not been wholly suppressed. Thus in Italy:

Prosecutors admit that they avoid the requirement of

249 Goldstein \& Marcus, supra note 223, at 267-68.

${ }^{230}$ Casper \& Zeisel, supra note 243, at 152 n.22. The fact that deliberation time is affected very little by confession suggests that, in most cases, this time is largely devoted to sentencing issues.

${ }^{281}$ Id. at 149-50.

${ }^{252}$ Goldstein and Marcus observed that Casper and Zeisel had not examined the lowest tier of West German courts where large numbers of minor offenses are tried. In what appears to be a nonsequitur, the authors argued that trials in these courts "may well be shorter and, as a result, even more substantially affected by the accused's confession." Goldstein \& Marcus, supra note 223, at 268 n.68.

25s. Weigend, supra note 224, at 411 (citing D. Dobling, Die Zwertellung Der HaUPTVERHANDLUNG 221 (1978)).

2st Goldstein \& Marcus, supra note 223, at 268.

285 The authors also noted that the West German penal order procedure was "a direct analogue of the American guilty plea." Id. at 267. For discussion of this procedure, see Langbein \& Weinreb, supra note 248, at 1565-67; see also supra notes 128-223 and accompanying text. 
mandatory prosecution by the manner in which they appraise the credibility of witnesses, weigh the evidence, and assign burdens of proof. For example, when a woman of "tarnished" reputation alleges that she was raped by an established person who has no previous record, the prosecutor may make comparative assessments of credibility and decline to proceed on the basis of insufficient evidence, even though he could easily send the case to trial. ${ }^{288}$

Fortunately the rule of compulsory prosecution does permit prosecutors to assess questions of credibility in deciding whether there is an adequate evidentiary basis for prosecution, and it is not clear that the case suggested by Goldstein and Marcus involved a departure from the rule. Certainly a judgment concerning the strength of the evidence cannot be wholly mechanical, and one may readily accept the suggestion of Goldstein and Marcus that, in close cases, "[c]ompassion intrudes now and then."267 Nevertheless, to say that the rule of compulsory prosecution is subject to interpretation or even that it may be bent is not to say that the rule means nothing or that the discretion exercised by European prosecutors is even remotely comparable to the essentially unfettered charging discretion of prosecutors in the United States. More importantly, the exercise of a unilateral charging discretion that, far from inducing a defendant to convict himself, may save him from prosecution is plainly no analogue of plea bargaining. ${ }^{258}$

Goldstein and Marcus ultimately suggested that two European practices bore a resemblance to American plea bargaining. In France, even when the available evidence strongly suggests that a defendant has committed a serious offense within the jurisdiction of the Court of Assize, a French prosecutor may use the process of "correctionalization" to charge a lesser offense triable in the correctional court whose procedures are less elaborate. ${ }^{259}$ The defendant, however, may object to this correctionalization and may insist upon standing trial on the more serious charge in the higher court. ${ }^{260}$ Goldstein and Marcus maintained that when a French prosecutor uses the process of correctionalization, he "is, in effect,

2se Goldstein \& Marcus, supra note 223, at 271.

${ }^{267}$ Id. at 280. For a sensitive analysis of the rule of compulsory prosecution, see Damãska, supra note 224.

${ }^{288}$ See Stlmerman Book Review, supra note 4, at 1032 ("To say that mercy should be given is not to say that mercy should be sold.").

25s Goldstein \& Marcus, supra note 223, at 277.

260 Id. at 250. 
offering an accused a lesser sentence . . . in exchange for a waiver by the accused of the full process that he would have if he were charged with a [more serious crime]."261 This argument may be literally accurate, especially if one wishes to view a defendant's failure to insist that he should be prosecuted for a more serious offense as a waiver of procedural protections. ${ }^{262}$ Nevertheless, a defendant whose case is correctionalized does not concede his guilt of any crime. He retains his right to trial and to the full range of legal protections considered appropriate for the only offense with which he has been charged. A similar situation might arise if an American defendant charged only with a finable offense in a nonjury court were permitted to insist (as he is not) that he should be charged with a more serious crime in a court where he could receive a jury trial. Although most defendants would be likely to decline the honor, they probably would not think that they had engaged in plea bargaining. Goldstein and Marcus's analogy between plea bargaining and correctionalization simply indicates that some Americans go to extremes in the attempt to prove that everyone else subverts procedural protections just as we do. ${ }^{263}$

Goldstein and Marcus's final contention was that "[i]n return for an admission of guilt ... prosecutors may recommend suspended sentences or lenient ones, and judges may impose them."204 In contrast to the authors' descriptions of other European practices, this seemingly central assertion received little attention and was unsupported by reference to any specific interview, any illustrative incident, or any European literature. ${ }^{265}$ Professor Langbein

${ }^{261}$ Id. at 277.

${ }^{202}$ Weigend, supra note 224 , at 408 , concluded that "[d]espite strong surface similarities between plea bargaining and correctionalisation, it does not appear that defendants are coerced into waiving their rights to more formal proceedings"; cf. Langbein \& Weinreb, supra note 248, at 1557 ("it would startle all those involved, the accused not least, to suggest that he has given up something when he does not insist on being prosecuted for a more serious offense").

${ }^{283}$ French prosecutors apparently do not use correctionalization to reward confessions. Weigend, supra note 224, at 409 . One reason may be that a French defendant is entitled to withdraw a confession at any time before conviction. Id. In addition, the decision to correctionalize takes place before there has been any opportunity to bargain. Id.

204 Goldstein \& Marcus, supra note 223, at 278.

${ }^{20 s}$ One disturbing aspect of the Goldstein and Marcus article lay in its apparent tendency to treat European sources as believable only when they reported the violation of legal norms. The article contained statements like this one:

It is difficult to tell whether the repeated affirmations of adherence to the norm of compulsory prosecution and the repeated denials of agreements between prosecutor and defense attorney reflect the underlying truth, or whether they are a product of the habit of officials to answer questions in terms of formal doctrine rather than actual practice. 
has advanced a substantially different view. In the West German system:

Confessions are tendered at trial not for reward, but because there is no advantage to be wrung from the procedural system by withholding them. The accused knows what prospective evidence is in the dossier, he knows what evidence the prosecutor has asked the court to take at trial, and he is always examined about the matters charged against him (although ... he has the privilege to remain silent).

People do not like to be caught lying, even people who have already been caught committing serious crimes. It is ordinary human nature not to deny the obvious when the truth is certain to come out anyway. ... .

... [T] tion that $41 \%$ of the cases [in West Germany] are so openand-shut that the defendants admit the charges for no better reason than that contest is hopeless. ${ }^{268}$

Langbein's analysis may offer at least as plausible an explanation of the forty-one percent confession rate in West Germany as the explanation advanced by Goldstein and Marcus, but of course neither analysis was based on a direct examination of European sentencing practices.

During the years that I have. been studying plea bargaining, I have encountered a number of lawyers, academics, and judges with backgrounds in Continental systems and other legal systems patterned on the Continental model. They have included a delegation of criminal law teachers from Mexican law schools, most of the members of the Penal Committee of the French National Assembly, a group of officials from the Afghanistan Ministry of Justice, and Johannes Andenaes of Norway, Jorn Vestergaard of Denmark, Hans G. Rupp and Klaus Rolinski of West Germany, Dusan Cotic and Bostjan M. Zupancic of Yugoslavia, and Zdenek Krystufek, an American professor who had taught law for twenty years in Czechoslovakia. Conversations with these sources obviously can provide only a tentative basis for judgments about legal practices outside

Id. at 270. Perhaps Goldstein and Marcus did not suggest the distinction between theory and practice in their questions; perhaps they suspected that this distinction was too subtle for European lawyers to understand even when the researchers presented it; or perhaps they simply suspected that virtually all European lawyers and judges were dishonest.

${ }^{268}$ Langbein, supra note 130, at 219-21. Professor Langbein also emphasized the immense difference between the $41 \%$ confession rate in West Germany and the much higher guilty plea rates in the United States. Id. at 220. 
the United States, but in the absence of more systematic empirical study, they may be worth something.

All of these sources confirmed the absence of explicit bargaining for confessions in their countries, and they noted that if any form of prosecutorial or judicial bargaining came to light, it would render the resulting confessions inadmissible. When I asked whether confession might be viewed on occasion as evidence of remorse, all of the sources agreed that it might. To my surprise, a few suggested that it would be illegal to consider a defendant's confession even when it plainly evidenced remorse, but they admitted that this legal stricture might not be observed perfectly and that "judges are human, too." ${ }^{267}$ With only a single exception, however, ${ }^{268}$ the sources denied that a defendant's confession was likely

${ }^{267}$ Weigend maintained that "most German courts consider a voluntary confession a mitigating factor in sentencing," noting that the "practice is of dubious legality." Weigend, supra note 224, at 411. Formal legal doctrine in West Germany, however, does not sanction even trivial inducements to confess. The West German supreme court has said, "[I]t is forbidden to punish more leniently the criminal who confesses, solely on account of his confession." 1 Entscheidungen des Bundesgerichtshofes in Strafsachen [BGHSt] 105, 106 (W. Ger. 1951), translated in Langbein, supra note 130 , at 221 \& n.61. The same decision declared the impropriety of inducing defendants to confess "through the threat of disadvantage-such as a more severe sentence." Id. at 106.

Professor Langbein, like Professor Weigend, conceded that West German courts sometimes reward confession, but unlike Professor Weigend, he apparently based his concession on formal legal doctrine-specifically, a statute that permits a court to consider along with many other factors a defendant's "conduct after the crime, especially his efforts to make amends for the harm." Langbein, supra note 130, at 221 n.60 (citing Strafgesetzbuch (criminal code) [STGB] $\S 46$ (W. Ger. 1975)). The reference to a defendant's efforts to make amends for his crime seems on its face to speak more of acts like restitution and victim compensation than of confession. In fact, Casper and Zeisel translated the relevant statutory language somewhat differently than Langbein did. They read it to say that a court might consider the defendant's "conduct after the act, especially his endeavor to make restitution." Casper \& Zeisel, supra note 243, at 165 . Their rendering of the statute avoids conflict between this statute and the West German supreme court decision described above, and my literate and knowledgeable colleague Hiroshi Motomura reports that the word that Langbein translated as "to make amends for the harm"-wiedergutzumachen-is more commonly translated as "to make reparations." This word is used, for example, in the German equivalent of the phrase "make reparations of war."

Apart from formal doctrine, Professor Langbein has noted that manuals on the defense of criminal cases in West Germany have discussed whether it may be tactically advantageous for defendants to confess. These manuals report that a confession may permit "counsel to narrow and direct the court's attention to ameliorating factors in the accused's background and his criminal conduct." Langbein, supra note 130, at 221 n.61. In contrast to the extensive discussions of plea bargaining in similar American volumes, the manuals offer no hint that a defendant's confession is likely to be rewarded with a more lenient sentence. Id. at 215 \& n.40 (citing H. Dahs, Handbuch Des StrapVerteidigers (4th ed. 1977); H. Schorn, Der Strafverteidigers (1966)).

${ }^{268}$ Apart from Professor Vestergaard, see supra note 237, a letter from Professor Fritz W. Scharpf of West Germany recognized the possibility that some implicit bargaining might occur in his country. Scharpf ultimately took an agnostic position, however: "It is hard to 
to be rewarded in a systematic way. A typical statement was that of Professor Andenaes: "If a defendant were to confess before any significant evidence against him had come to light, his confession might seem relevant, but a judge ordinarily would not regard a confession as relevant to sentencing if it has been made when there was no way out."268

Because these authorities agreed that a defendant's confession might affect his sentence on some occasions, I asked whether defense attorneys might advise their clients of this possibility and whether some defendants might then confess in the belief that this act could lead to some reward. Again with only one exception, my sources insisted that judicial rewards for self-incrimination were so small and sporadic that a defense attorney could not properly encourage a client to confess on this basis. When I observed that even an outside chance of a minor reward might lead a defendant to confess if he had very little chance of acquittal, they replied that in any event defense attorneys do not give this advice and that defendants are not encouraged to confess. Moreover, these sources generally bridled at any suggestion that European sentencing practices might serve the same function as American plea bargaining; they used words like "ridiculous" and "unthinkable."

Subjective perceptions of sentencing practices may be more important in assessing the extent to which legal systems encourage confession than the sentencing practices themselves. One may hope that when European sentencing practices are studied in a systematic way, scholars will devote some attention, not only to what the courts do in fact, but to the advice that defense attorneys give their clients and to the perceptions of defendants. 270

say whether something similar to plea bargaining goes on in order to obtain confessions." Letter from Professor Scharpf to author (Oct. 17, 1967).

200 Interview with Johannes Andenaes, supra note 231.

Dusan Cotic observed that, at one time, a code provision in Yugoslavia had indeed declared that an admission should be treated as evidence of repentance. He noted, however, that this provision had been repealed because it seemed to threaten a penalty for a defendant's denial of his alleged crime. In addition, the first question asked of the defendant at a Yugoslavian trial was once whether he considered himself guilty of the crime charged. Again, however, the code provision requiring this question had been repealed because even this question seemed unfairly to seek a confession. Today, after the defendant is asked about his education, family, and the like, he is usually asked only, "What have you to say in your defense?" Cotic noted some irony in the fact that no more than $30 \%$ of Yugoslavian defendants admit their guilt. "Your legal ideology seems to be much more opposed to selfincrimination than ours. You do not ask a defendant even to give an account of himself. Nevertheless, you have lots of confessions and we don't." Interview with Dusan Cotic, Yugoslavian lawyer, in Chicago (Mar. 14, 1968).

270 One also may hope that empirically-minded scholars will distinguish as best they 
Of course European legal systems should not be regarded as immobile alabaster masterpieces in which no deviations from legal norms have ever occurred. Much more extensive research on whether European practices serve in even a small degree as functional equivalents of plea bargaining would be desirable. Even without further research, however, and even if one brings a healthy dose of American skepticism to the inquiry, it seems undeniable that European practices are very different from our own. Whether or not a French defendant who accepts the correctionalization of his case should be regarded as waiving procedural protections and whether or not the minority of Continental defendants who confess are sometimes rewarded for this act, it is idle to pretend that all legal systems are the same under the skin. At a time when many thoughtful observers are deeply disillusioned by American criminal procedure and when European systems are regarded with apparent equanimity, it is appropriate to ask how these systems have avoided, if perhaps imperfectly, our disturbing subversion of the right to trial.

Of the many reasons for the lack of plea bargaining on the Continent, the most important is the relative simplicity of the European trial. The West German system offers an especially suitable illustration of how an essentially plea bargaining-free system can operate, for the literature in English about West German criminal justice is especially rich;"271 West Germany seems to avoid the rapid

can between a simple failure to confess and the presentation of a contrived defense-a task that would seem more difficult in European than in American systems because very few European defendants do remain silent. Certainly one who opposes the imposition of a penalty for the exercise of a right as basic as the right to trial need not also oppose the imposition of a penalty for false testimony. See United States v. Grayson, 438 U.S. 41, 52-55 (1978) (defendant's apparent perjury may be considered an aggravating circumstance in sentencing); United States v. Mandujano, 425 U.S. 564, 584, 609 (1976) (unanimous agreement that even if the fifth amendment privilege against self-incrimination would have entitled a defendant both to remain silent before a grand jury and to be advised of this right, it did not excuse his perjury).

Nevertheless, most of the Continental sources with whom I spoke insisted that even a defendant who advanced an obviously fabricated defense at trial probably would not receive a more severe sentence as a result. Most judges would regard this attempted deception as a natural thing to do. The same tolerant attitude may be indicated by the fact that, although German defendants are questioned at their trials, they are not placed under oath, and their false answers are not punishable as perjury. W. Schaerer, The Suspect and Society 71 (1967). Both an ideological opposition to penalizing defendants for tactical decisions and a matter-of-fact recognition that courts rarely can distinguish accurately among defendants on the basis of their attitudes may account for the apparent reluctance of Europeans to reward confessions even informally.

${ }^{271}$ See, e.g., Ass'n Internationale de Droit Penal, The Criminal Justice System of the Federal Republic of Germany (1981); The German Code of Criminal Procedure (H. 
case processing that Goldstein and Marcus discovered in France; ${ }^{272}$ and West German criminal procedure is in some ways closer to ours than is that of other European nations. ${ }^{273}$

Americans often harbor serious misconceptions about Continental trial procedures. ${ }^{274}$ One persistent myth is that Continental

Niebler trans. 1965); J. LangBein, supra note 242; Casper \& Zeisel, supra note 243; Damãska, supra note 224; Felstiner, supra note 133; Felstiner \& Drew, supra note 129; Goldstein \& Marcus, supra note 223; Herrmann, The German Prosecutor, in Discretionary Justice IN Europe AND America 16 (K. Davis ed. 1976); Herrmann, supra note 240; Jescheck, The Discretionary Powers of the Prosecuting Attorney in West Germany, 18 AM. J. Comp. L. 508 (1970); Jescheck, Principles of German Criminal Procedure in Comparison with American Law, 56 VA. L. Rev. 239 (1970); Langbein, Mixed Court and Jury Court: Could the Continental Alternative Fill the American Need?, 1981 Am. B. Found. RESEARch J. 195; Langbein, supra note 130; Langbein, supra note 240; Langbein \& Weinreb, supra note 248; Schram, The Obligation to Prosecute in West Germany, 17 AM. J. Comp. L. 627 (1969); Sessar, Prosecutorial Discretion in Germany, in The Prosecutor 255 (W. McDonald ed. 1979); Weigend, supra note 224.

272 Goldstein \& Marcus, supra note 223, at 253-54; see Casper \& Zeisel, supra note 243, at 152 n.22. West Germany also seems to devote greater resources to its courts than France does. See infra notes 303-08 and accompanying text; Johnson \& Drew, This Nation Has Money for Everything-Except Its Courts, Judges' J., Summer 1978, at 8, 11.

27 See J. LANGBEIN, supra note 242, at 2.

${ }^{274}$ These misconceptions sometimes find their way into the scholarly literature. Professor Graham Hughes has written:

[T] he German system depends for its trial efficiency on the existence of an elaborate pretrial procedure that presents the trial court with a complete dossier containing depositions and the work-up of the case by a magistrate who has examined the accused and witnesses. Indeed, it is possible to regard the "real trial" in Europe as taking place before the examining magistrate so that the later public trial only serves two principal functions-first, to "review" the magistrate's determination of the validity of the case against the accused and, second, to bring out all the facts necessary for a proper determination of the sentence. The conservation of judicial resources through the creation of a leaner trial mode might not be significant if it had to be accompanied by setting up cadres of magistrates to conduct the complex pretrial procedures found in Europe. Furthermore, for such procedures to become the centerpiece of a criminal prosecution, conducted in camera as they are in Europe, would be alien, if not odious, to our traditions and constitutionally unacceptable.

Hughes, Pleas Without Bargains, 33 RuTGkrs L. REv. 753, 756 (1981) (footnote omitted).

For the proposition that the efficiency of the West German trial system depends upon the pretrial work of an examining magistrate, Professor Hughes cited Professor Langbein. Langbein, however, had written something else. The office of the examining magistrate does not exist in West Germany; the preparation of criminal cases for trial is the task of the public prosecutor. Langbein, supra note 130, at 207-08 (the material cited by Hughes, supra, at 756 n.12); see also J. LANGBEIN, supra note 242, at 2 ("German pretrial procedure is closer to American than that of many other European systems, because in Germany the public prosecutor performs functions that in France and elsewhere are left to a more alien figure, the investigating magistrate.").

It may not be of critical importance whether a nation calls the official who prepares criminal cases for trial a judge or a prosecutor. The West German and American terminology may seem preferable because it calls attention to the possibility that this official, despite the rhetoric of impartiality that surrounds his office, will not be entirely disinterested. In any event, use of the West German label might have led Professor Hughes to the proper 
defendants are presumed guilty. In West Germany, ${ }^{27 s}$ and in France, ${ }^{276}$ however, the standard of persuasion is not significantly different from our standard, beyond a reasonable doubt. ${ }^{277}$ Moreover, the word "inquisitorial" as applied to Continental procedure probably conveys a false impression. European procedures incorporate significant adversary safeguards, and Europeans themselves often describe their systems as "mixed." Alth Although in Europe the presiding judge usually has primary responsibility for questioning the witnesses at trial, the prosecutor and defense attorney may pose additional questions and, at least in West Germany, submit closing arguments. ${ }^{279}$ In addition, West German procedure recognizes a privilege against self-incrimination. ${ }^{280}$ The trial begins with a judicial examination of the defendant, but he is instructed that

comparison. To duplicate the West German system, it would not be necessary for Americans to set up cadres of magistrates. We already have prosecutors. These prosecutors already are expected to-and sometimes do-prepare their cases for trial (which is all that Hughes seems to mean when he refers to "complex pretrial procedures," Hughes, supra, at 756).

The function of European trials is no more to review European prosecutors' (or magistrates') decisions to charge than the function of American trials is to review our prosecutors' charge decisions. In both European and American systems, a defendant can be convicted lawfully only if the evidence presented at trial establishes his guilt with a very high degree of certainty. See J. LANGBEIN, supra note 242, at 79. Moreover, there is no apparent reason to conclude that European tribunals defer informally to pretrial prosecutorial (or magisterial) decisions to a greater extent than American judges and juries do. Finally, pretrial proceedings in Europe certainly are no more in camera than the pretrial work of prosecutors' offices here.

Indeed, I know of only four significant differences between the pretrial work of European magistrates and prosecutors and the work of their American counterparts. First, European magistrates and prosecutors have a clearer obligation to investigate factual circumstances favorable to the accused. Id. at 90-91. Second, they have a clearer obligation to disclose all of the results of their investigations to the defense. Id. Third, their investigations are likely to be more thorough and the results more carefully recorded. Fourth, their tentative conclusions of criminal guilt are more regularly tested at trial. In most of these respects, the European procedure seems more favorable to defendants than the American. It is difficult to see anything in the European approach to trial preparation that is "alien, if not odious, to our traditions and constitutionally unacceptable," Hughes, supra, at 756.

${ }^{278}$ Langbein, supra note 130 , at 208.

27878 Harv. L. Rev. 460, 461 \& n.15 (1964).

277 J. LANGBEIN, supra note 242 , at 79.

${ }^{278}$ Goldstein \& Marcus, supra note 223, at 242 n.7; see Herrmann, The German Criminal Justice System: The Trial Phase-Appellate and Review Proceedings, in The Criminal Justice System of the Federal Republic of Germany 65 (1981); see also Kötz, supra note 224 , at 485 .

279 See J. LaNGBein, supra note 242, at 32-35. Moreover, the defendant need not rely entirely on his counsel. He, too, can question the witnesses and make a closing statement. See id. at 65 (citing Strafprozessordnung (code of criminal procedure) [STPO] $§ 258$ (W. Ger. 1975)).

${ }^{280} I d$. at 72 (citing STPO $\S 136$ (W. Ger. 1975)). 
he need not answer. ${ }^{281}$ In West Germany, moreover, the court is forbidden to draw an adverse inference from the exercise of this legal privilege. ${ }^{282}$ There is, however, no privilege analogous to the Anglo-American privilege not to take the witness stand, and perhaps because silence in the face of detailed questions concerning a criminal accusation is unnatural and is likely to seem incriminating whatever the legal rules, nearly all West German defendants do tell their stories. ${ }^{283}$ West German trial procedure is therefore more inquisitorial than ours, although one should not overlook the fact that our accusatorial ideals have been so perverted by plea bargaining that American officials commonly expect, not merely an answer from the defendant, but what they regard as the right answer-an unqualified affirmation of guilt.

West German procedure promotes popular participation in the administration of criminal justice but does not employ what, despite its democratic virtues, has become the most cumbersome factfinding mechanism that humankind has devised, the twelveperson jury. All except the most trivial cases are heard by mixed tribunals of lay and professional judges, and although the size and composition of these tribunals varies with the seriousness of the offense charged, the lay judges always have sufficient voting power to force an acquittal. ${ }^{284}$ Because West German lay judges are subject to disqualification only on the same narrow grounds that justify the disqualification of professional judges, West German procedure is not burdened by the voir dire examinations of prospective jurors that prolong American jury trials. ${ }^{285}$ Also absent are our elaborate jury instructions ("If you find A, you must consider B, and if you find B . . .")-instructions that also lengthen the trial and that, most studies indicate, jurors do not understand. ${ }^{286}$ Because the lay and professional judges deliberate to-

281 Id. (citing STPO § 243 (W. Ger. 1975)).

282 Id.

2as See id.; Damãska, Evidentiary Barriers to Conviction and Two Models of Criminal Procedure: A Comparative Study, 121 U. PA. L. Rev. 506, 527 (1973).

284 J. LANGBeIN, supra note 242, at 63 (citing STPO \& 263 (W. Ger. 1975)). The only limitation of the lay judges' power to force acquittal arises from the power of the prosecutor to appeal a judgment of acquittal. If an appellate court composed entirely of professional judges concludes that the acquittal was erroneous (and if both the court and the prosecutor are willing to accept the minimum punishment prescribed by law), the appellate court can order the defendant convicted without remanding the case for a new trial. Id. at 84-85 (citing STPO $\$ 354$ (W. Ger. 1975)). This facet of West German procedure is designed to preclude the nullification of disfavored laws by lay judges. Id. at 85 .

$2 s s$ See id. at 142.

${ }^{286}$ See, e.g., A. Elwork, B. SAles \& J. Alfini, Making JuRy Instructions UnderstandABLE (1982) (average juror in a criminal case might understand only half of the instructions 
gether, the professionals can explain points of law as they become relevant. An adversary check on the accuracy of the legal positions that they adopt is provided by a detailed written judgment that sets forth both the court's legal positions and its factual conclusions and that can (and often does) lead to wide ranging appellate review at the behest of either the prosecution or the defense. ${ }^{287}$

Many American evidentiary rules seem difficult to defend even in our jury system (for example, the rule that forbids leading questions on direct examination after a lawyer has spent hours discussing a witness's testimony with him before trial ${ }^{288}$ ). Nevertheless, it may be the absence of a jury system rather than greater common sense that accounts for the absence of these complicating rules in West Germany. ${ }^{289}$ West German witnesses usually are permitted to present their testimony in narrative form. The principles of "orality" and "immediacy" designed primarily to preclude the introduction into evidence of statements contained in a pretrial dossier that have not been presented orally at trial, ${ }^{290}$ provide a weak analogue to our hearsay rule, but many forms of documentary evidence that would be inadmissible in the United States-including the recorded but unsworn. statements of witnesses who have become unavailable-can be considered. ${ }^{291}$ With a very few exceptions like the limited hearsay rule ${ }^{282}$ and the rule against receiving involuntary confessions, ${ }^{203}$ West German procedure does not exclude evidence on the ground that its prejudicial impact may exceed its probative value; this kind of exclusion seems to occur primarily in systems that claim to value the common sense of juries but that trust only the less common sense of judges and rulemakers to determine the worth of various sorts of evidence. Moreover, West Germans have enough confidence in the disciplinary mechanisms applicable to their statewide, hierarchically con-

presented); Charrow \& Charrow, Making Legal Language Understandable: A Psycholinguistic Study of Jury Instructions, 79 CoLUM. L. REv. 1306, 1308-09 \& n.8 (1979) (critically reviewing prior studies); Schwarzer, Communicating with Juries: Problems and Remedies, 69 CALIF. L. REv. 731, 740 (1981); Severance \& Loftus, Improving the Ability of Jurors to Comprehend and Apply Criminal Jury Instructions, 17 LAw \& Soc'y REv. 153 (1982).

${ }^{287}$ J. LANGBEIN, supra note 242, at 84 n.7 (citing StPO § 296 (W. Ger. 1975)).

${ }^{288}$ See FED. R. Evm. 611(c).

${ }^{289}$ A somewhat similar relaxation of evidentiary rules has occurred in the United States in some cases tried without juries. See, e.g., United States v. Compania Cubana De Aviacion, 224 F.2d 811, 821 (5th Cir. 1955).

290 See J. LANGBeIN, supra note 242, at 67 (citing SrPO § 250 (W. Ger. 1975)).

291 See id.

392 See supra note 290 and accompanying text.

${ }^{393}$ See J. LangBern, supra note 242, at 69 (citing StPO $\$ \S 69,136 a$ (W. Ger. 1975)). 
trolled police forces that they have little interest in adopting exclusionary rules to deter police misconduct. ${ }^{294}$

Because "virtually all relevant evidence is admissible, ... . time is not spent arguing about exclusion and otherwise manipulating evidence in the familiar Anglo-American ways."205 In addition, a pretrial procedure that provides virtually complete discovery to the defense (and that permits the defense to seek the investigation at public expense of material that the police and prosecutor may have overlooked) limits the importance of surprise and forensic strategy at the trial. ${ }^{298}$ The practice of beginning the trial with an examination of the accused also tends to identify which matters are contested and thus to focus the issues. ${ }^{287} \mathrm{Be}-$ cause "[v]irtually all of the features of German court structure that strike an Anglo-American observer as distinctive have the effect of accelerating the conduct of the trial by comparison with our own arrangements," 298 Professor Langbein has concluded, "German trial procedure, unlike American, has retained an efficiency that makes trial practical for every case of imprisonable crime."289

It is not only the relative simplicity of the European trial that has made plea bargaining in West Germany unnecessary. Criminal caseloads are less burdensome in Europe than in the United States largely because crime rates there are much lower. ${ }^{300}$ In addition, West Germany has legalized some formerly criminal conduct, ${ }^{301}$ and in an effort both to reduce judicial workloads and to eliminate

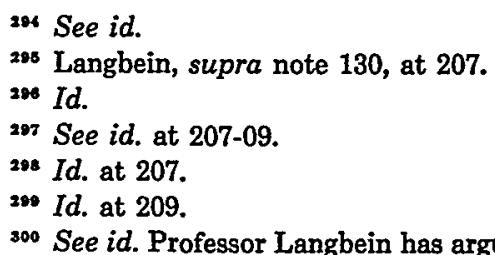
divert a larger portion of its criminal cases to the various nontrial channels that it has already established. Id. at 209-10. It seems noteworthy that the number of West German criminal defendants did increase $30 \%$ between 1965 and 1976. Sessar, supra note 271, at 272.

s01 Sessar, supra note 271 , at 257. Felstiner and Drew have indicated, for example, that prostitution is punishable in West Germany only when the solicitation occurs near a church. Felstiner \& Drew, supra note 129, at 24. There has even been serious discussion in West Germany of decriminalizing one property offense-the theft from a self-service store of goods worth less than $\$ 200$. A distinguished study group has proposed that victims of this theft should be entitled merely to civil recovery of both the goods and an amount of money equal to their value. See Felstiner \& Drew, Should Some Theft Be Decriminalized?-A Look at the German Experience, JUDGEs' J., Fall 1978, at 16, 19. A somewhat similar provision has been enacted in East Germany. See Kaiser, Recent Developments in German Penal Policy, 4 Int'l J. Criminology \& Penology 193, 197 (1976). 
the criminal stigma from regulatory and other minor violations, it has substituted administrative for criminal proceedings in many cases involving traffic, health, and environmental regulations and in some cases involving more traditional criminal prohibitions as well. ${ }^{302}$

Finally, West Germany, like most other European countries, devotes far greater resources to its courts than do American jurisdictions. A study by Earl Johnson Jr. and Ann Barthelmes Drew concluded that the United States does have a significant edge in the number of lawyers. "The number of practicing lawyers for each judge in California is more than ten times West Germany's ...." Nos Nevertheless, the public resources devoted to the administration of justice in the United States are smaller. There are only one-third as many professional judges per capita in the United States as in West Germany. ${ }^{304}$ Moreover, this discrepancy does not seem to be the product of our poverty. While the United States employs 42.7 professional judges per billion dollars of national income, West Germany employs $90 .^{305}$ Even with traffic cases set aside, the average California judge disposes of six times as many cases as the average West German judge. ${ }^{308}$ In view of the very different allocation of responsibilities between lawyers and judges in European and American jurisdictions, even an adequately funded American legal system might require fewer judges than the West German, just as an adequately funded West German system might require fewer lawyers than the American. ${ }^{307}$ Nevertheless,

${ }^{302}$ See Felstiner \& Drew, supra note 129, at 24; Sessar, supra note 271, at 256-60.

sos Johnson \& Drew, supra note 272, at 10 (footnote omitted).

sot Id.

sos Id.

${ }^{308}$ Id. at 11. With traffic cases included, the ratio of cases per judge becomes 20 times greater in California than in West Germany. Id. Not only do West German taxpayers support more judges than American taxpayers, but the number of prosecuting attorneys in West Germany increased by $35 \%$ between 1965 and 1976-approximately as rapidly as the number of criminal suspects, see supra note 300 , and more rapidly than the number of filed cases. Sessar, supra note 271, at 258, 261-62.

${ }_{807}$ Professor Langbein emphasized this fact in his vigorous criticism of the JohnsonDrew study. Although Langbein did not dispute any of the study's findings, he objected that the authors have undertaken their comparison of American and European legal systems on a purely quantitative basis, disregarding the qualitative differences between our adversarial and the Europeans' nonadversarial procedures. These qualitative differences are the true source of the quantitative differences. Johnson and Drew derived erroneous implications for the manning of American courts because they ignored those characteristics of European procedure that explain European manpower levels.

Langbein, Judging Foreign Judges Badly: Nose Counting Isn't Enough, JudGEs' J., Fall 1979 , at $4,4$.

Unlike Professor Langbein, I did not understand Johnson and Drew to argue that the 
the experience of West Germany and other European nations ${ }^{308}$ should cause Americans to blush when they consider the claim that plea bargaining is an economic necessity. If the resources devoted to our criminal courts are inadequate to implement our constitutional ideals, that circumstance seems to be the product, not of necessity, but of choice.

\section{B. The Process That Is Due: The Constitution and the Conti- nent, the Criminal and the Courts}

Until 1968, the very end of the Warren Court era, the Supreme Court had said repeatedly, "Consistently with [the due process clause of the fourteenth amendment,] trial by jury may be abolished." 309 That year, however, the Court decided Duncan $v$. Louisiana ${ }^{310}$ and declared, "[W]e hold that the Fourteenth Amendment guarantees a right of jury trial in all [state] criminal cases which-were they to be tried in a federal court-would come within the Sixth Amendment's guarantee." and other decisions "incorporating" provisions of the Bill of Rights within the fourteenth amendment's due process clause, it commonly is assumed that a revision of American trial procedures to embody the dominant features of Continental justice would require "either constitutional amendment or radical reinterpretation of the Bill of Rights by the Supreme Court."312 In fact, however, neither constitutional amendment nor a judicial reinterpretation of the federal Constitution would be necessary.

Duncan's "incorporation" of the right to jury trial was qualified by a critical assumption that many criminal justice scholars have tended to overlook. Footnote fourteen of this opinion merits

United States should have more judges simply because West Germany and other European nations do. Plainly the demonstration that American courts are understaffed must come from another source. If, however, the claim that plea bargaining is an economic necessity has any foundation, this demonstration of the inadequacy of our resources should not be difficult. The Johnson-Drew study does suggest that greater social effort on our part is conceivable and that the "realists" who dismiss this option out of hand are not truly realists.

sos Comparisons of our judicial expenditures with those of several other European nations are presented in Johnson \& Drew, supra note 272. These comparisons are less dramatic than comparison with West German expenditures, but they are still extremely striking.

${ }^{309}$ Snyder v. Massachusetts, 291 U.S. 97, 105 (1934); see, e.g., Irvin v. Dowd, 366 U.S. 717, 721 (1961); Fay v. New York, 332 U.S. 261, 288 (1947); Palko v. Connecticut, 302 U.S. 319, 324 (1937); Jordan v. Massachusetts, 225 U.S. 167, 176 (1912); Maxwell v. Dow, 176 U.S. 581, 603 (1900); Missouri v. Lewis, 101 U.S. 22, 31 (1879).

s10 391 U.S. 145 (1968).

s11 Id. at 149.

s12 Hughes, supra note 274 , at 756 . 
quotation at length:

[R]ecent cases applying provisions of the first eight Amendments to the States represent a new approach to the "incorporation" debate. Earlier the Court can be seen as having asked, when inquiring into whether some particular procedural safeguard was required of a State, if a civilized system could be imagined that would not accord the particular protection.

The recent cases, on the other hand, have proceeded upon the valid assumption that state criminal processes are not imaginary and theoretical schemes but actual systems bearing virtually every characteristic of the common-law system that has been developing contemporaneously in England and in this country. The question thus is whether given this kind of system a particular procedure is fundamental-whether, that is, a procedure is necessary to an Anglo-American regime of ordered liberty. It is this sort of inquiry that can justify the conclusions that state courts must exclude evidence seized in violation of the Fourth Amendment . . . [and] that state prosecutors may not comment on a defendant's failure to testify. ...

... Of each of these determinations that a constitutional provision originally written to bind the Federal Government should bind the States as well it might be said that the limitation in question is not necessarily fundamental to fairness in every criminal system that might be imagined but is fundamental in the context of the criminal processes maintained by the American States.

When the inquiry is approached in this way the question whether the States can impose criminal punishment without granting a jury trial appears quite different from the way it appeared in the older cases opining that States might abolish jury trial. A criminal process which was fair and equitable but used no juries is easy to imagine. It would make use of alternative guarantees and protections which would serve the purposes that the jury serves in the English and American systems. Yet no American State has undertaken to construct such a system. ${ }^{313}$

It would be strange and unfortunate if the federal Constitution were read to preclude states from seeking workable alternatives to our existing regime of criminal justice-a regime so costly 
and so far beyond the states' perceived capacities that the Supreme Court and other observers regard the avoidance of its procedures through plea bargaining as a necessity. Duncan was the high water mark of selective incorporation, and it is extremely doubtful that today's Supreme Court would carry an incorporationist view of the fourteenth amendment beyond the limits of that decision. Of course this Court and others would scrutinize carefully any departure from a traditional model of American criminal justice to insure that it reflected a fair and balanced effort to promote effective law enforcement and the dignity of defendants. No procedure that served merely as a "cover" for limiting the rights of defendants would be likely to receive judicial approval nor should it. ${ }^{314}$ Nevertheless, the current Supreme Court would be extremely unlikely to condemn a simplification of American trial procedures, including a major restriction of the use of criminal juries, simply on the theory that the sixth amendment and other provisions of the Bill of Rights automatically apply to the states by virtue of the fourteenth amendment. Instead, as Duncan revealed, the issue would be whether a state had constructed a procedural system that the Supreme Court said could be easily imagined but that no state had adopted-one that "was fair and equitable but used no juries.".318

Liberated from the incorporationist assumptions that often infect discussions of state criminal procedure, states might consider a variety of reforms that could make trials more accessible without an increase in criminal justice expenditures. For example, although a state might retain the traditional Anglo-American jury for homicide cases, obscenity prosecutions, and other criminal proceedings in which the play of community sentiment is invited by vague legal standards, ${ }^{318}$ it might prefer mixed tribunals of lay and profes-

sis Of course, a substantially simplified state trial procedure might include some revision of the doctrines of Miranda v. Arizona, 384 U.S. 436 (1966), Griffin v. California, 380 U.S. 609 (1965), and Mapp v. Ohio, 367 U.S. 643 (1961). Nevertheless, a state could not appropriately assume that the dissatisfaction with these decisions expressed by various $\mathrm{Su}$ preme Court Justices, see, e.g., Bivens v. Six Unknown Named Agents of Fed. Bureau of Narcotics, 403 U.S. 388, 420-22 (1971) (Burger, C.J., dissenting), would lead these Justices to approve a procedural system designed primarily to revise particular constitutional rulings.

316 Duncan, 391 U.S. at 150 n.14.

s1s These proceedings might include those in which defendants assert defenses like insanity and necessity. They also might include cases in which political crimes are alleged (assuming that an appropriate definition of the term or an appropriate list of "political" charges could be devised). 
sional judges for most other cases. ${ }^{317}$ As in Europe, the lay judges probably ought to have at least the collective voting power needed to force an acquittal, ${ }^{318}$ but to satisfy our traditional concern for a very high degree of certainty of guilt, a state might go beyond the European model and require the unanimous concurrence of the lay and professional judges as a prerequisite to conviction. If, as Duncan argued, the principal reason for entrusting the administration of justice to nonprofessionals is to check official arbitrariness, ${ }^{310}$ it may be more appropriate to use nonprofessionals as a check than to yield them the entire field. In a system of mixed tribunals, lay judges might have less practical power over the administration of criminal justice than they currently have in the American jury system, ${ }^{320}$ but the greater influence of professional judges need not automatically be regretted and often might work to the benefit of defendants. ${ }^{321}$ As a group, legally trained judges may be alert to governmental abuses in ways that nonprofessionals often are not, and perhaps a system of mixed tribunals could best utilize the distinctive virtues of both groups in determining issues of guilt and punishment. ${ }^{\text {222 }}$

The use of mixed tribunals might facilitate other reforms that also would limit the complexity of trial procedures. A thorough examination of the merits and demerits of substantially revised trial

317 See Langbein, supra note 271 , passim.

318 See supra note 284 and accompanying text.

s1o Duncan, 391 U.S. at 151.

s20 See Casper \& Zeisel, supra note 243, at 185-91. But see J. LangBein, supra note 242, at $137-38$.

321 Casper and Zeisel sometimes seemed to intimate disapproval of the extent to which professional judges influence lay judges in West German mixed tribunals. See Casper \& Zeisel, supra note 243 , at 189-91. Nevertheless, my reaction to the two authors' many descriptions of mixed-tribunal deliberations was that when the influence of the professional judges did prove decisive, it almost invariably led to more appropriate results. This reaction may not be surprising in view of the fact that I am a law-trained professional myself; but of course, in every case, one or more of the lay judges were persuaded to the same view. For example, in one of the cases described in the Casper and Zeisel study, the defendant was a member of a gang that had been removing cigarette machines and stealing their contents. When surprised by the police, members of the gang had shot at the officers. The lay judges voted initially to convict the defendant of aggravated robbery on the ground that professional criminals should be punished as severely as the law permits, but one or more of the professional judges apparently persuaded them that the defendant's crimes were only grand larceny and resisting a peace officer. Id. at 158-59. Of course a properly instructed American jury might have reached the same verdict, but it may have been fortunate for the defendant in this case that a direct interchange between the lay and professional judges could occur.

${ }^{322}$ Discussions of the American jury system have tended to romanticize our citizenry as a group of hearty yeomen ever alert to incursions on their liberty, see, e.g., H. KaLveN \& H. ZErSEL, supra note 91, at 219, 236-37, 310-11, but the American citizenry includes some people who t' row rocks at children to prevent school integration. 
procedures might require a number of articles as long as this one, and it certainly would carry a study of plea bargaining far from its central focus. The discussion that follows therefore does not pretend to be exhaustive. It indicates very briefly some paradoxes of current American procedures and how they might be remedied in a system of mixed tribunals. Although the positions that this discussion advances are no more tentative than the other positions asserted in this article, the purpose of presenting them in an abbreviated form is mostly to demonstrate that the paradoxes are serious and that the proposed remedies are worthy of consideration quite apart from their facilitation of a plea bargaining prohibition. A later section of the article will consider whether some of the procedural problems described in this section could be remedied to some extent within the context of a traditional Anglo-American jury system.

Like other aspects of our current system of jury controls, our jury selection procedures present significant paradoxes. The selection of a jury typically requires more time in the United States than a trial requires from beginning to end elsewhere in the world. Our procedures effectively insure the absence of invidious discrimination at the earliest stages of selection, but ultimately they permit prosecutors and defense attorneys to challenge prospective jurors on the basis of race and other stereotypical characteristics. ${ }^{323}$ In effect, our system guarantees minorities an opportunity to reach the finals before it discriminates against them; trial-practice manuals typically advise lawyers to seek or avoid blacks, Hispanics, women, people with physical afflictions, teachers, free thinkers, hunters, master sergeants, Jews, Lutherans, and flower children. ${ }^{324}$ Partly to facilitate this use of peremptory challenges, lawyers freely probe the private attitudes and practices of prospective jurors, asking questions that undoubtedly would provoke an outraged reaction if asked of citizens in other governmental contexts. ${ }^{325}$ Nevertheless, the available evidence strongly suggests

32s Swain v. Alabama, 380 U.S. 202, 220-22 (1965). But see People v. Wheeler, 22 Cal. 3d 258, 276-77, 583 P.2d 748, 761-62, 148 Cal. Rptr. 890, 903 (1978); People v. Payne, 106 Ill. App. 3d 1034, 1040, 436 N.E.2d 1046, 1050 (1982); Commonwealth v. Soares, 377 Mass. 461, 488, 387 N.E.2d 499, 509, cert. denied, 444 U.S. 831 (1979).

s24 See W. WAGNER, ART of Advocacy: JuRy Selection § 1.04 (1981); J. Sparling, Jury Selection in a Criminal Case (unpublished, undated training manual used in the District Attorney's Office, Dallas, Texas, on file with The University of Chicago Law Review).

sss In a drunk driving prosecution, for example, it apparently is routine to ask prospective jurors about their drinking habits, their driving habits, and their religious beliefs. See Oster \& Simon, "We Want As Biased a Jury as We Can Get," Chicago Sun-Times, June 19, 1974, at 4, col. 1, at 10, col. 2 ("For the next two days, the prospective jurors would . . . be 
that, after our extended jury selection proceedings are concluded, a lawyer seeking only his client's tactical advantage is almost as likely to guess incorrectly as to guess correctly in deciding which prospective jurors to challenge. ${ }^{326}$ In the end, the selection of people to perform an important governmental function on the basis of racial, ethnic, religious, and sexual characteristics serves no substantial purpose.

Lawyers commonly value the jury selection process not so much because it yields better juries as because it gives them an opportunity to try their cases before they try them. ${ }^{327}$ The devotion of substantial resources to voir dire examinations, to the investigation of prospective jurors outside the courtroom, and also to the typically substantial waiting time of the prospective jurors themselves seems unjustifiable in a system supposedly so impoverished that it is unable to afford trials to more than a small minority of defendants. In a system of mixed tribunals, by contrast, lay judges might be assigned to cases on the same basis as professional judges and might be subject to disqualification only on the same grounds that would support the disqualification of the professional judges.

asked hundreds of questions about their jobs, their spouses' jobs, their sons' and daughters' jobs, and their sons- and daughters-in-laws' jobs"); see also W. WAGNER, supra note 324, MQ 4-30 (suggesting model questions for attorneys to ask on voir dire).

${ }^{328}$ Zeisel \& Diamond, supra note 219, at 514-18. See Broeder, Voir Dire Examinations: An Empirical Study, 38 S. CAL. L. Rev. 503, 505 (1965) ("Voir dire was grossly ineffective not only in weeding out 'unfavorable' jurors but even in eliciting the data which would have shown particular jurors as very likely to prove unfavorable.").

${ }^{327}$ A lawyer's goals typically include impressing upon prospective jurors the lawyer's theory of the case, emphasizing particular points of law, and charming them completely. Charles R. Garry offered an illustration of this process in a presentation at the University of Washington Law School in Seattle on June 23, 1979, "Packaging Voir Dire, Opening and Closing Argument." He suggested asking a prospective juror whether, as he viewed the defendant at the counsel table, the defendant was guilty or innocent. The prospective juror was likely to answer that of course he did not know. Garry suggested challenging this prospective juror for cause on the ground that he was unwilling to accord the defendant the presumption of innocence. Garry recognized that the challenge was unlikely to be successful, but he thought that it would forcefully impress the presumption of innocence upon the jurors ultimately seated.

I once mentioned Garry's remarks as offering extreme examples of the waste and abuse that can occur during voir dire. A California prosecutor responded, however, that Garry's tactics were not extreme. Indeed, every defense attorney whom he knew routinely asked some prospective juror whether the attorney's client was guilty or innocent, and most of these defense attorneys thought it a sad comment on the state of civil liberties in America that so many prospective jurors responded truthfully that they simply did not know.

Cf. Broeder, supra note 326, at 522 ("Conservatively, about eighty per cent of the lawyers' voir dire time was spent indoctrinating, only twenty per cent in sifting out the favorable from the unfavorable veniremen. [Nevertheless, i]ndoctrination did not often appear to succeed."). 
American procedures are almost as paradoxical at trial as at the earlier stage of jury selection. Despite our professed faith in jurors, we regard them as incapable of understanding the worth of evidence that they routinely evaluate in their everyday activities. At least we say that we do not trust them; our practice may be different. The enforcement of America's rules of evidence frequently depends on what Justice Jackson called "[t]he naive assumption that prejudicial effects can be overcome by instructions to the jury, ... . [an assumption that] all practicing lawyers know to be unmitigated fiction." ${ }^{\text {"328 }}$ Sometimes, to be sure, our procedure rejects this fiction and seeks a more effective control. Jurors are ushered in and out of the courtroom as lawyers conduct hearings on evidentiary issues-arguing, for example, about whether a witness's half-hour description of how a business record was prepared sufficiently authenticated the record to warrant its admission in evidence. ${ }^{329}$

Despite all of the time and energy devoted to jury selection, the enforcement of evidentiary restrictions, the frequently belabored probing of factual issues, the lengthy arguments of counsel, and the delivery of complex jury instructions, our system of jury controls often does not work. Indeed, the jurors themselves may reveal that they have based their verdict on improper considerations or even that they have returned a verdict other than the one that they meant to return, in one instance by convicting a defendant whom they meant to acquit. ${ }^{330}$ In this situation, judges invoke the rule that jurors may not impeach their own verdicts. ${ }^{3 s 1}$ The

328 Krulewitch v. United States, 336 U.S. 440, 453 (1949) (Jackson, J., concurring) (citation omitted).

s28 I once observed a homicide prosecution in which there was no doubt that the alleged victim had died. Nevertheless, when the prosecutor attempted to introduce a hospital record to establish this fact, the defense attorney resisted; the jury was excused; a hospital administrator testified about the way in which the record had been prepared; both attorneys argued at length about the adequacy of the administrator's testimony; the trial judge ruled that the record was admissible; and the jury returned to the courtroom after nearly an hour of idleness.

230 In Sellars v. United States, 401 A.2d 974 (D.C. 1979), nine of twelve jurors testified that they had accepted the defendant's claim of self-defense and had meant to acquit when they convicted him of manslaughter. Id. at 983 (Mack, J., dissenting). Both the trial court and the Court of Appeals refused to set the manslaughter verdict aside. Cf. M. GLeisser, JURIBS AND JUSTICE 171 (1968) (describing a case in which two jurors admitted that they and their fellows had failed to realize that a conviction without a recommendation of mercy carried a death sentence so that they had condemned a defendant to death without meaning to do so).

322 See, e.g., United States v. Green, 523 F.2d 229, 235 (2d Cir. 1975) (compromise verdict), cert. denied, 425 U.S. 950 (1976); Domeracki v. Humble Oil \& Ref. Co., 443 F.2d 1245, 1247-48 (3d Cir.) (failure to follow instructions), cert. denied, 404 U.S. 883 (1971); Jorgenson 
refusal to know embodied in this rule reflects what we know already-that our system of jury controls often fails. If verdicts could be set aside whenever juries had seriously misconstrued the judge's charge, rendered compromise verdicts in defiance of the court's instructions, considered for one purpose evidence admitted only for another, given substantial weight to evidence not admitted at all, treated a defendant's failure to testify as evidence of his guilt, or acted on the basis of some manifest prejudice, substantial numbers of jury verdicts probably could not stand. ${ }^{\mathbf{3 2} 2}$

A system of mixed tribunals could check the possible misconduct of lay judges more effectively than the elaborate courtroom procedures that we currently use for this purpose. Of course this system would require its own rules of evidence-rules of relevancy and privilege and even, perhaps, a rule excluding from evidence the products of illegal searches and seizures. Most rules based on the perception that the prejudicial impact of some evidence outweighs its probative value, however, could be abandoned. These patronizing rules are of dubious merit even in our jury system. ${ }^{\mathbf{3 3}}$ If

v. York Ice Mach. Corp., 160 F.2d 432, 435 (2d Cir.) (agreement to abide by majority vote), cert. denied, 332 U.S. 764 (1947); Sellars v. United States, 401 A.2d 974, 982 (D.C. 1979) (described supra note 330 ).

ss2 See J. Frank, Courts on Trial 115 (1950); F. James \& G. Hazard, Civil Procedure 310 (2d ed. 1977).

Perhaps what we say that we want juries to do and what we truly want them to do are two different things. On the one hand, we tell juries to follow the law; on the other hand, when juries do not follow the law, they serve the purposes of the jury system. If we were to talk out loud about these extralegal purposes, we might emphasize them too much. Perhaps we achieve the best blend of law and community sentiment when we pretend, contrary to fact, that law is all we want. In other words, we can assume, if we like, that our lying is poetry and that everything turns out for the best in the end. It might be difficult to maintain this romantic viewpoint, however, if we looked more closely at what happens in jury rooms.

sss 'The worth of these rules depends not only on their authors' understanding of the limited value of certain sorts of evidence but also on the conclusion that jurors will lack the same understanding. The judicial arrogance that must have informed these rules is suggested by the following early defense of the hearsay rule:

[U]pon the minds of a jury unskilled in the nature of judicial proofs, evidence of this kind would frequently make an erroneous impression. Being accustomed, in the common concerns of life, to act upon hearsay and report, they would naturally be inclined to give such credit when acting judicially; they would be unable to reduce such evidence to its proper standard when placed in competition with more certain and satisfactory evidence; they would, in consequence of their previous habits, be apt to forget how little reliance ought to be placed upon evidence which may so easily and securely be fabricated; their minds would be confused and embarrassed by a mass of conflicting testimony; and they would be liable to be prejudiced and biassed by the character of the person from whom the evidence was derived.

T. Starkie, Evidence 55 n.1 (9th Am. ed. Philadelphia 1869) (1st ed. London 1824); see also In re Berkeley, 4 Camp. 402, 415, 171 Eng. Rep. 128, 135 (H.L. 1811). 
law-trained judges could caution lay judges against the misuse of evidence and other abuses and also could use their own voting power to prevent abuse, the most burdensome aspects of our current system of jury controls would become superfluous.

A state thus could go far toward simplifying its trial procedures without reassessing two basic tenets that have differentiated American and European systems-adversariness and a reluctance to use the accused as a source of evidence. With some reassessment of these tenets, however, a greater simplification of American trial procedures might be achieved.

Our adversary system rests on a sound perception that the prejudices and limitations of a single fact-gatherer may lead him to overlook important considerations and relevant data. To overcome this tendency, the adversary system effectively preordains the prejudices of two advocates and directs them to find whatever evidence they can to support their assigned positions. In the main, this system reflects an intelligent division of labor in marshaling evidence and argument.

Nevertheless, the writings of Marvin E. Frankel have documented the excesses and failures of our lawyer-dominated approach to truth seeking. ${ }^{384}$ Although Judge Frankel has proposed remedying these defects primarily by modifying the ethical responsibilities of advocates, ${ }^{385}$ a number of critics have suggested that his proposals would be both unworkable in practice and unsound in principle. ${ }^{388}$ The courtroom procedures of continental Europe suggest a more appropriate approach. A "mixed" system of adversarial and nonadversarial procedures could permit advocates to counteract the prejudices and limitations of judicial fact gatherers while it encouraged the emergence of truth, not simply from the clash of two distinct perspectives, but from the interplay of three.

As our adversarial procedures have traditionally operated, witnesses have been divided into two camps. After hearing those who testify "for" the state, a jury hears those who testify "for" the defendant. In addition, each witness's testimony is divided into two parts, first the part that may favor the party who called him and

ss4 See M. Frankgl, Partisan Justice (1980); Frankel, The Search for Truth: An Umpireal View, 123 U. PA. L. REv. 1031 (1975).

sss See, e.g., Frankel, supra note 334, at 1057-59.

sse See Alschuler, The Preservation of a Client's Confidences: One Value Among Many or a Categorical Imperative?, 52 U. CoLo. L. Rzv. 349 passim (1981); Alschuler, The Search for Truth Continued, The Privilege Retained: A Response to Judge Frankel, 54 U. CoLo. L. REv. 67 (1982); Kötz, supra note 224; Pizzi, Judge Frankel and the Adversary System, 52 U. Colo. L. Rev. 357 (1981). 
then, on cross-examination, the part that may favor his opponent. These two parts do not always make a whole, and no one bears responsibility for seeking information that the advocates were afraid (or forgot) to develop. ${ }^{\text {ssz }}$

A relatively minor modification of our adversarial procedures would give judicial officers greater responsibility for supplementing the evidentiary presentations of counsel. ${ }^{338}$ A more substantial modification would require judges to control the order of proof at trial and to conduct the initial examination of witnesses. Of course a presiding judge could not perform these functions unless he had learned something of the facts of a case prior to trial, but the preparation of a detailed pretrial dossier of the sort employed in Europe would be unnecessary. Instead, opposing lawyers might supply the judge with lists of witnesses whom they thought should be heard along with a summary of each witness's anticipated testimony. ${ }^{339}$

This use of adversarially compiled witness lists might encourage a substantially different procedure from that customary on the Continent. ${ }^{340}$ In light of his limited information and his need to remain impartial, a judge's examination of witnesses ordinarily would be cursory. He would determine when each witness should be heard, invite the witness's narrative testimony, ask obvious questions, and-prompted by counsel if necessary-intervene when the testimony strayed from relevant issues. A more detailed probing of the witness's testimony would remain the task of the opposing attorneys, each of whom could cross-examine the witness in turn.

With this basic revision of courtroom procedure, the efficiency and the coherency of the trial process might be enhanced. Separate issues could be treated separately-for example, by placing opposing expert witnesses on the stand after one another-and each wit-

ssz See Pizzi, supra note 336, at 366.

sss Judges currently have the power to call witnesses not called by the parties and to ask questions that they have failed to ask, FED. R. Evm. 614; see also Johnson v. United States, 333 U.S. 46, 54-55 (1948) (Frankfurter, J., dissenting), but they rarely exercise this power, see Fink, The Unused Power of a Federal Judge to Call His Own Expert Witness, 29 S. CAL. L. REv. 195 (1956).

ss9 Perhaps the prosecutor also should be expected to reveal to the presiding judge the identity of people whose testimony he considered unnecessary but whom he believed to possess relevant information.

sso Indeed, one might hope that it would. The passive role of lawyers at European trials gives rise to legitimate concern about the extent to which Continental procedure truly achieves the virtues of a mixed system. See J. LangBern, supra note 242, at 64-65 (discussing West German practice). 
ness might be permitted to give his version of the "whole truth" before opposing advocates tested what he said. Not only the use of a more limited pretrial "dossier" but also our stronger adversarial traditions would be likely to make our "mix" of adversarial and nonadversarial approaches to factfinding different from the "mix" exhibited by European systems. Nevertheless, some movement in the European direction could promote both a more dignified treatment of witnesses and a more complete, coherent, and accurate process of fact determination in the courtroom.

In addition to its other virtues, this reform would promote equality in the administration of criminal justice. Despite our claim that the kind of trial a person gets should not depend on the amount of money he has ${ }^{341}$ (and despite substantial progress toward the achievement of this goal), the American legal system probably makes the kind of justice that a defendant receives more dependent on the quality of the lawyer whom he is able to hire than any other legal system in the world. The defendant most disadvantaged in our system probably is not the indigent defendant represented by a public defender but the defendant who, because he does not have much money or because he does not know better, is represented by one of the hangers-on of the private bar who frequently appear in criminal cases. This lawyer's primary goal usually is to pocket a quick fee by entering a plea of guilty, ${ }^{342}$ but even on the infrequent occasions when this lawyer takes a case to trial, the trial judge will do little to protect the defendant from his attorney's apparent inadequacies. The greater the trial court's responsibility for development of the facts, the less the defendant with an inadequate lawyer is likely to suffer.

Of course affording a more active role to the presiding judge at trial might reduce an outstanding attorney's ability to work his magic. Still, this lawyer would be able to submit any argument that he could have submitted in a fully adversarial system, to insist that any witnesses with relevant information be heard, and to ask any questions that he thought should be asked. If the presiding judge had overlooked a line of inquiry that seemed potentially helpful to the defendant, his lawyer could pursue it. For these reasons, the defendant with an able lawyer probably would not be greatly disadvantaged by the nonadversarial aspects of a "mixed" procedure, while the disadvantage of the defendant with an inadequate or marginally competent lawyer might be lessened. 
The issue that may capture best the differing philosophies of American and European legal systems is the role of the defendant at his trial. American criminal procedure seems to view the defendant primarily as an object-a target of the coercive forces of the state. His dignity consists of his passivity, his ability to proclaim to the state, "Thou sayest," and his constitutional right to force the government to "shoulder the entire load." The Supreme Court has described the privilege against self-incrimination-including the defendant's right to remain silent at his trial-as the essential mainstay of our accusatory system. ${ }^{343}$ In a European trial, by contrast, the defendant rarely remains silent. He is given both the first word at his trial and the last; he ordinarily may present his testimony as he likes rather than simply in response to the inquiries of counsel; he may question other witnesses himself; and if the unexpected develops, he is asked immediately for his comment. ${ }^{344}$

Certainly Americans bring to the criminal trial a view of human dignity different from the view that they adopt in other contexts. As Justice Walter V. Schaefer has suggested, no parent or schoolteacher feels guilty about asking questions of a child strongly suspected of misconduct. ${ }^{\text {345 }}$ Similarly, no employer considers it improper to ask an employee accused of wrongdoing to give his side of the story. Indeed, criminal cases aside, there are apparently no investigative or factfinding proceedings in which asking questions and expecting answers is regarded as dirty business. ${ }^{346}$

Nevertheless, our accusatorial rhetoric has been one thing and our inquisitorial practices another. Short of restoration of the rack and the thumbscrew, a more blatant mockery of accusatorial ideals than today's practice of plea bargaining is difficult to conceive. In addition, Americans seek the self-incrimination of defendants through police interrogation. Miranda $v$. Arizon $a^{347}$ held that the

sts Malloy v. Hogan, 378 U.S. 1, 7 (1964).

s4 See, e.g., J. LANGBEIN, supra note 242, at 25, 65 (discussing West German procedure).

ss W. SchaEFER, supra note 270, at 59 ("[T] incrimination . . . runs counter to our ordinary standards of morality. Parents try hard to inculcate in their children the simple virtues of truth and responsibility.").

${ }^{348}$ See McCormick, Law and the Future: Evidence, 51 Nw. U.L. REv. 218, 222 (1956) ("Ordinary morality . . . sees nothing wrong in asking a man, for adequate reason, about particular misdeeds of which he has been suspected and charged. . . . I predict that the weaknesses of the privilege [against self-incrimination] in point of policy and morality will become more widely understood."). For an elegant analysis of the "ordinary morality" of expecting answers in the investigative process and a discussion of its relevance to issues of constitutional interpretation, see Greenawalt, Silence as a Moral and Constitutional Right, 23 WM. \& MARY L. REv. 15 (1981).

s\$7 384 U.S. 436 (1966). 
products of custodial interrogation could be used at trial only when a suspect had made a knowing waiver of his right to remain silent. As Judge Frankel has commented, however, and as any lawyer will advise any suspect, "rational people do not condemn themselves advisedly in the stationhouse." $\$ 48$ Frankel has noted that the target of a door-to-door vendor currently is allowed a few days of tranquil reflection before the law holds him to the purchase of a vacuum cleaner. ${ }^{349}$ If criminal suspects were afforded a similar opportunity to reconsider their more momentous choices made in a more coercive atmosphere, few of their supposedly intelligent waivers would be likely to survive. ${ }^{350}$ Apart from a handful of remorseful suspects, another handful who may seek conviction for political or other reasons, and a third handful who are innocent and able to clear themselves by talking, virtually no one under arrest makes a truly knowing and voluntary waiver of Miranda rights.

Miranda, designed in part to promote equality between the knowledgeable and the naive in the administration of justice, may instead have accentuated the disparity between suspects who are smooth and sophisticated and those who are slow and easily imposed upon. Each year, courts find multitudes of intelligent waivers by suspects who, had they understood their situations in the slightest degree, surely would have remained silent.

The reasons for rejecting in practice the accusatorial rhetoric that we proclaim in theory are powerful; nevertheless, the manner in which we have done so is absurd. Criminal defendants are close to the best source of evidence for resolving criminal disputes, and they should be expected to provide it-the dons of organized crime no less than the hapless people who yield today to police interrogation. A fair and balanced resolution of the problem is apparent, and it has been proposed repeatedly by respected judges and scholars. $^{\text {s51 }}$

318 Frankel, From Private Fights Toward Public Justice, 51 N.Y.U. L. REv. 516, 527 (1976); see M. FrANKRL, supra note 334, at 95-100.

s9 M. FrANKEL, supra note 334, at 97-98.

sso Id.; Frankel, supra note 348, at 527-28.

${ }^{381}$ In his dissenting opinion in Lakeside v. Oregon, 435 U.S. 333, 345 n.5 (1978), Justice Stevens commented that "the roster of scholars and judges with reservations about expanding the Fifth Amendment privilege reads like an honor roll of the legal profession." He then cited works by Wigmore, Corwin, Pound, Friendly, Schaefer, and Traynor. At least four of the six honorees-Wigmore, Pound, Friendly and Schaefer-had manifested their reservations about expanding the fifth amendment privilege by endorsing proposals for judicially supervised interrogation. See also Frankel, supra note 348, at 530; Kamisar, Kauper's "Judicial Examination of the Accused" Forty Years Later-Some Comments on a Remarkable Article, 73 Mich. L. REv. 15, 33 (1974). 
Following a judicial determination of probable cause, ${ }^{362}$ a suspect should be questioned in the presence of his counsel before a magistrate. His answers in this safeguarded environment should be admissible at trial. Of course these answers might tend to prove the suspect's guilt because they were incriminating, seemed internally contradictory, rang untrue in certain details, or were inconsistent with the suspect's defense at trial. Equally, however, the answers might tend to prove the suspect's innocence by showing that he had denied his guilt promptly, in a manner consistent with his trial defense and in apparently forthcoming answers to specific questions..$^{363}$ If the suspect refused to answer, this refusal also should be admissible at trial both because it would have a rational bearing on his guilt and because its admission would express society's judgment that defendants, like other witnesses, should respond to orderly inquiry.

This interrogation, somewhat comparable to the taking of a party's deposition in a civil case, would be likely to promote accurate factfinding both when accurate factfinding would help the defendant and when it would hurt him. Moreover, the defendant's counsel should have a reciprocal opportunity promptly to depose witnesses who might testify against his client. ${ }^{354}$ To make the safeguards of this procedure effective, no statements made in response to custodial police interrogation should be received in evidence.

ss2 Like a police search, interrogation invades a suspect's privacy and should not be permitted without antecedent justification. For a discussion of the important moral differences between interrogation based on slender suspicion and interrogation based on substantial suspicion, see Greenawalt, supra note 346.

One collateral virtue of judicially supervised interrogation is that it would encourage police officers to bring suspects before magistrates promptly, for it would be only before magistrates that admissible confessions could be obtained. This reform would promote a prompt advisement of rights, a prompt bail determination, and a prompt determination of probable cause.

sss Remarkably, permitting the defendant to present this probative evidence would require some modification of our arcane evidentiary rules. Today, the hearsay rule often prevents defendants from introducing evidence of their prior consistent statements. These statements become admissible only when the prosecutor has opened the door by advancing "an express or implied charge . . of recent fabrication or improper influence or motive." FED. R. Evid. 801 (d)(1)(B). The fact that the prosecutor has accused the defendant of a crime and introduced evidence of his guilt, moreover, carries no door opening implications. This circumstance is never enough in itself to permit the defendant to bolster a current denial of guilt with proof of an earlier willingness to submit to interrogation and of the detail and consistency of his responses. United States v. Navarro-Varelas, 541 F.2d 1331, 1334 (9th Cir. 1976), cert. denied, 429 U.S. 1045 (1977).

364 Today, by contrast, although discovery depositions are routine in civil cases, even liberal criminal discovery rules ordinarily do not permit defendants or their attorneys to depose prosecution witnesses. See Fed. R. Crim. P. 15(a); Standards Relating to Pretrial Discovery and Procedure Berore Trial § 2.5 (1970). 
A defendant also should be expected to testify at trial, and a trier of fact should be permitted to draw an adverse inference from his failure to do so. At the same time, the process of impeachment by prior convictions-itself a substantial impediment to the use of that "most efficient testimonial resource," the evidence of defendants themselves-ought to be eliminated. ${ }^{355}$ In accepting Duncan's apparent invitation ${ }^{356}$ to devise a more balanced, more rational (and more affordable) system of procedure, a state might resolve the contradictions of America's use of defendants as a source of evidence just as it might end the paradoxes of many other aspects of American trial procedure. ${ }^{367}$

Some Americans favor subversion of the right to trial through plea bargaining, not primarily for economic reasons, but because they regard current trial procedures as defective. Scholars proclaim, "Plea bargaining is best understood as an adaptive process in which the prosecutor, defense attorney and judge attempt to

${ }^{235}$ The use of prior convictions for impeachment purposes could be eliminated either by forbidding their use altogether or by permitting their introduction as part of the prosecutor's case in chief. Descriptions of mixed tribunal deliberations in West Germany indicate that the tribunals give considerable weight to the always admitted evidence of prior convictions, but as I read these descriptions, they do not support the fear that a tribunal may convict a previously convicted defendant simply because he is an evil person and not because he committed the crime alleged. Indeed, a clean record may help a defendant more than a bad record would hurt him. In one West German case, a defendant accused of attempting to rob a jewelry store claimed, not only that he had not attacked the store owner, but that the store owner had attacked him. Although this story seemed dubious, the defendant had no prior criminal record and was personally appealing in other ways. Two lay judges forced an acquittal over the dissent of the one professional judge. Casper \& Zeisel, supra note 243 , at 159 .

One of the nonjury trials that I observed in Philadelphia in 1968, see infra notes $412-90$ and accompanying text, offered a striking comment on the American rule that ordinarily excludes evidence of a defendant's prior criminal convictions unless he testifies. The charge was purse snatching, and the state's case depended upon the victim's identification of the defendant. At the conclusion of the trial, the judge announced that he had a reasonable doubt of the defendant's guilt and that he would acquit. He then said, "Mr. Prosecutor, let me see if I got it right." The prosecutor, with a resigned nod, handed the judge a copy of the defendant's prior criminal record, one apparently indicating the defendant's involvement in a number of similar offenses. "Oh hell, I blew it," said the judge. I was impressed both by the judge's willingness to play by the rules and by the rules' artificiality. The judge resembled a quiz show contestant awaiting the opening of a sealed envelope with the correct answer.

sso See supra notes 309-15 and accompanying text.

ssz See Greenawalt, supra note 346 , at 46 ("Insofar as a very expansive right to silence before and at trial impedes efficient ascertainment of guilt, it contributes to a guilty plea alternative that treats an accused with little respect and concern."). Of course, even without "unincorporating"-or "divesting"- the fifth amendment privilege from the fourteenth amendment's due process clause, the Supreme Court might reinterpret the fifth amendment to authorize the procedures suggested in text. See id. at 42-43, 52-59. 
... infuse a sense of realism in the implementation of absurdly excessive rules and procedures." hopeless that even a lawless system seems better, the time probably has come for their revision.

This article's review of the defects of the American trial and of ways in which trial procedures might be simplified has been extremely cursory. It should be apparent, however, that substantially simplified procedures derived in part from European models might be preferred even to the procedures that our system promises but does not deliver. When these simplified procedures are compared not to what we say but to what we do, the issues become far less balanced and debatable.

The foregoing discussion neglected the most obvious advantage that a substantially simplified system of criminal procedure would yield-one that would not lie in this system's selection of factfinding tribunals, its simplified rules of evidence, its blend of adversarial and nonadversarial procedures, or its use of the accused as a source of evidence. The most significant change that this system would effect would lie in its treatment of the right to trial. Like its European progenitors, this system would permit the abolition of plea bargaining and make a trial available to every defendant who sought one.

If Americans were to back their professed ideals of criminal justice with the resources necessary to implement them, they might conceivably assert the advantages of American procedure over the more straightforward alternatives suggested above. On the assumption that the subversion of our trial procedures through plea bargaining has become a necessity, however, there is little doubt that these alternatives would better provide the process that is due.

For the moment, the prospect of revising American trial procedures to incorporate significant features of continental justice is probably a pipe dream. Although, as this article has argued, the federal Constitution would pose no significant obstacle to this reform, state constitutional guarantees of the right to jury trial and of other traditional features of American criminal procedure undoubtedly would. The processes of amending state constitutions, although less burdensome than those of amending the federal Constitution, are burdensome enough. Moreover, a proposal for altering the traditional incidents of the American trial is likely to sound 
shockingly subversive to those whose views of criminal justice are derived from Law Day rhetoric rather than from what happens in our courts. Paradoxically, those who view themselves as civil libertarians might be the first to resist indignantly a proposal actually to afford American defendants some rights for a change.

Nevertheless, the day may come when Americans will seek alternatives to a criminal justice system that sometimes seems more a ravaged ideological battleground than a functioning social institution. In place of today's curious blend of repressiveness and libertarian sentiment, they may seek a system that works. Certainly that day may come if the schizophrenia of our present system remains unresolved while its promises are ever more clearly abandoned. If the thesis suggested by our ideals and the antithesis suggested by our practices are to find their synthesis in a more balanced, more attainable procedure, responsible students of criminal justice ought to begin the process now by considering proposals for reform that are unlikely to be adopted and implemented tomorrow.

\section{Less Sweeping Reforms}

Short of reshaping trial procedures in a European mold-and without any influx of resources-Americans could implement a variety of reforms that would make trials more available. This section will review briefly (and in a far from definitive fashion) seven proposals for conserving current criminal justice resources. These proposals, each of which has become the subject of its own scholarly literature, are (1) to prosecute less, (2) to use existing court capacity more effectively, (3) to limit the availability of postconviction remedies, (4) to reduce the size of criminal juries, (5) to simplify jury selection procedures, (6) to simplify evidentiary rules, and (7) to use videotape technology in assembling and presenting trial testimony..$^{359}$

1. Prosecute Less. A plea bargaining prohibition might strain existing resources, but probably not to the point that it would imperil the justice system's capacity to prosecute murderers, rapists, and armed robbers. It seems substantially more likely that prose-

sss Of course this section, like the rest of this article, proceeds from a strongly anti-plea bargaining perspective. Admittedly, I prefer almost any system of trial procedure that guarantees an impartial tribunal and an opportunity to be heard to almost any system of plea bargaining. Readers who do not share this viewpoint may not consider the restriction of plea bargaining an important enough goal to justify some of the economies discussed in this section; they may need to draw some finer lines. 
cutors faced with a prohibition of plea bargaining would screen their cases more thoroughly and insist on stronger evidence as a prerequisite to prosecution, and also that they would forgo more often the prosecution of drug users, nude swimmers, and dirty book sellers. ${ }^{360}$ Of course, many observers of American criminal justice would regard intensified prosecutorial screening as a virtue rather than as a defect. ${ }^{361}$

Legislatures also could liberate existing resources by decriminalizing some victimless conduct. Although this article is not the place to explore in a very serious way our law's embroilment in the morals business, the emergence of plea bargaining occurred at about the same time as a significant expansion in the scope of the criminal law in the late nineteenth and early twentieth centuries (especially the enactment of new liquor prohibition statutes by local, state, and national governments). ${ }^{362}$ In the 1960 's, moreover, felony caseloads more than doubled as the result in part of an explosion in the number of marijuana prosecutions; ${ }^{.363}$ at the end of this period, plea bargaining suddenly became respectable, gaining the endorsements of the American Bar Association, ${ }^{364}$ the President's Commission on Law Enforcement and Administration of Justice, ${ }^{365}$ and the Supreme Court. ${ }^{366}$ Certainly the contribution of victimless crime to the perceived pressure for plea bargaining has not been trivial. As recently as 1971 , "every second case on the Los Angeles criminal court docket [was] a pot offense [and] every fourth arrest across the nation a [public drunkenness] case."38r Prosecuting consensual behavior less would offer one way to reduce

${ }^{300}$ Following the prohibition of plea bargaining in Alaska, prosecutors declined prosecution in $70 \%$ more drug cases than they had before the ban. The rate of declension in morals cases increased by $540 \%$. In one city, Fairbanks, the rate of declension also increased for fraud, forgery, and embezzlement cases, but there was no increase in the rate for more serious offenses. M. Rubinstein, S. Clarke \& T. White, supra note 56, at 139-40.

sei See, e.g., N. Morris \& G. Hawkins, The Honest Politician's Guide to Crime ConTROL 1-28 (1970); H. PACKER, supra note 147, at 249-366.

${ }^{362}$ See History, supra note 4, at 32; Mather, Comments on the History of Plea Bargaining, 13 LAW \& Soc'y REv. 281, 282-83 (1979).

${ }^{363}$ In California, the number of adult arrests for marijuana use increased from 3,300 in 1962 to 34,000 in 1968, and by the end of this period, marijuana violations accounted for approximately one-quarter of the state's felony complaints. J. KaPLAN, MaruJUANa 29 (1970). On the overall doubling of felony caseloads during the 1960's, see The Prosecutor's Role, supra note 4 , at 51 \& n.7.

set Standards Relating to Pleas of Guilty (1968).

ses U.S. President's Comm'n on law Enforcement \& Admin. of Justice, The ChalLenge of CRime in A Free Society 135 (1967).

${ }^{s 68}$ See, e.g., Brady v. United States, 397 U.S. 742, 752-53 (1970).

${ }^{887}$ Justice on Trial-A Special Report, supra note 65, at 18. 
substantially our reliance on bargained justice.

2. Use Existing Court Capacity More Effectively. Politicians are not always persuasive when they argue that potentially costly innovations can be financed simply by "trimming fat" elsewhere or by using existing resources more efficiently. With today's criminal justice system, however, the more effective use of current resources is not just a rhetorical possibility.

Anyone can test this proposition by walking through a criminal courthouse on a weekday afternoon and seeing how many courts are in operation. If this person's experience is like mine, he will find most courtrooms vacant, and on a Friday afternoon he will be lucky to find a single court in session. ${ }^{368}$ An investigation of the Circuit Court of Cook County, Illinois, revealed that the average judge spent only about two and three-quarters hours per day on the bench. ${ }^{369}$ Although the overwhelming majority of convic-

sa Cf. Oster \& Simon, Jury Trial A Sure Way to Increase the Rap, Chicago SunTimes, Sept. 17, 1973, at 4, col. 3, at 68, col. 1 (a Chicago Crime Commission survey revealed that between 40 and $60 \%$ of all circuit court courtrooms were vacant between 10:00 and 11:30 A.M. and between 2:00 and 3:30 P.M.).

s6s Simon \& Oster, Judges on Bench $23 / 4$ Hours a Day, Chicago Sun-Times, Jan. 20, 1974 , at 1 , col. 1 . The story added:

While judges argue that they spend essential work time off the bench in their chambers, spot checks of court clerks and other court personnel indicate that on the average this chambers time amounts to only another $1 \frac{1}{2}$ hours a day.

Along with the three-month court-watching study, more than a score of interviews were conducted with leading trial lawyers and assistant state's attorneys-those men who actually spend time in court and in chambers with judges. Opinion was nearly unanimous that while some judges work hard, most come to court late, leave early and do little if any useful work in chambers.

... [C]ourtrooms stand empty, unused and often locked on the average of more than five hours during the normal working day.

A variety of special methods were used in the study to give judges the benefit of the doubt:

(1) The legal court days preceding and following the Thanksgiving, Christmas, Hanukkah and New Year's holidays were excluded from the study.

(2) If a judge did not show up in court at all, that day was not included in the study. This means that if a judge chose to take the entire day off-a not uncommon occurence [sic], especially on Fridays-it was not counted against his average time in court.

....

[T] he average bench starting time was about 10:15 a.m., . . but about 45 minutes later, after 11 a.m., judges start leaving their courtrooms, some never to return.

... [B]y 3 p.m. the number of times judges appear on the bench is less than half the 10:30 a.m. total.

$\cdots$

As to the central debate-whether judges spend their time valuably and properly when they are off the bench-virtually every judge interviewed said they do and virtually every lawyer and assistant state's attorney said they do not. 
tions in this court were by guilty plea, the average number of dispositions per judge was only about one per working day. ${ }^{370}$

One cannot estimate with precision the unused capacity of our courts, but a report written principally by Whitney North Seymour Jr. for a New York citizens group concluded that more than sixtyfour percent of the money spent each year by the Criminal Court of New York City was "wasted." 771 The report noted, for example, that in 1978 the Criminal Court conducted 6878 preliminary hearings in felony cases that later were screened again by grand juries; it suggested that this duplicative pretrial screening was unnecessary. ${ }^{372}$ The report also observed that more than seventeen court appearances per case had become the norm in felony prosecutions resolved by the Supreme Court in New York City; it concluded that judges had been too liberal in granting continuances and that no more than six to nine appearances should be necessary. ${ }^{373}$ Certainly the experience of the one state that has attempted to manage its caseloads without plea negotiation indicates that a plea bargaining prohibition itself would be likely to spur important economies and reforms. ${ }^{374}$

Id. at 1 , col. 1 , at 4 , col. 1 .

s7o See Nardulli, The Caseload Controversy and the Study of Criminal Courts, $70 \mathrm{~J}$.

Crim. L. \& Criminology 89, 96-97 (1979):

If criminal court resources are examined in light of the procedures actually used to process cases, one might justifiably contend that many criminal court systems have considerable excess capacity. Clearly there was much idle time in the trial courts in Chicago. . . . Moreoever, throughout the two year period examined, the average number of dispositions [per judge was] about one per working day. This norm of a "disposition per day" is all the more remarkable when it is realized that during this time period approximately seventy percent of the dispositions were guilty pleas or dismissals.

s71 Castillo, supra note 50, at 1.

372 Citizens Action on Crime, Waste, Delay and Inefrectiveness 12 (1980). The annual cost to the taxpayers of preliminary hearings in cases later considered by grand juries was close to four million dollars. Id.

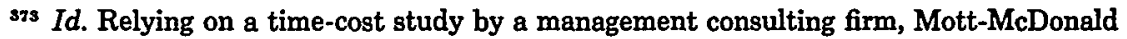
Associates, the report placed the annual cost of unnecessary court appearances in New York City at about 34 million dollars. Id. This amount is $12 \%$ of the additional expenditure that this article has estimated would be necessary to afford one-day trials to every felony defendant in America who reaches the trial stage. See supra note 94 and accompanying text.

s7t See supra note 56 and accompanying text. Justice Robert C. Erwin of the Alaska Supreme Court has observed:

"A no-plea-bargaining policy forces the police to investigate their cases more thoroughly. It forces prosecutors to screen their cases more rigorously and to prepare them more carefully. It forces the courts to face the problem of the lazy judge who comes to court late and leaves early, to search out a good presiding judge, and to adopt a sensible calendaring system. All of these things have in fact happened here."

Slloerman Book Review, supra note 4, at 1029 n.81 (quoting interview with the Hon. Robert C. Irwin, Associate Justice of the Alaska Supreme Court, in Anchorage (June 14, 1976)); see History, supra note 4, at 34 (statement of Judge Arthur L. Alarcon: "Prosecutors say 
Finally, to mention only briefly a development of importance, judicial administration has burgeoned as a distinct field of study within the past decade. It has produced an extensive literature on subjects such as effective calendar management, the uses of pretrial conferences, the better training of court employees, the virtues of computerized technology, and the more efficient utilization of jurors. ${ }^{375}$ To the extent that the considerable knowledge thus generated has not been put to use, it suggests a variety of ways in which current resources might go farther.

3. Limit the Availability of Postconviction Remedies. The review of a criminal conviction in the United States can be disjointed and prolonged.

Potential steps are these: (1) new trial motion in trial court; (2) direct appeal to state intermediate appellate court; (3) discretionary review in state supreme court; (4) discretionary review in Supreme Court of the United States; (5) petition for collateral review in state trial court; (6) appeal of the collateral proceedings to state intermediate appellate court; (7) discretionary review in state supreme court; (8) discretionary review in Supreme Court of the United States; (9) habeas corpus petition in federal district court; (10) appeal to U.S. Court of Appeals; (11) discretionary review in Supreme Court of the United States. ${ }^{378}$

In England, by contrast, where the complexities of our federal system are absent, a criminal conviction ordinarily is subject only to a single review on direct appeal. ${ }^{377}$

A 1976 study by Paul D. Carrington, Daniel J. Meador, and Maurice Rosenberg recommended both a unified state appellate procedure patterned after England's and a simplified federal habeas corpus procedure under which cases would enter the federal judicial system at the court of appeals level..$^{378}$ In 1981, a federal task force headed by Illinois Governor James R. Thompson and former United States Attorney General Griffin B. Bell proposed a

that bargaining is a way to reduce the backlog, but in reality it is simply a way to reduce the work.").

${ }^{273}$ See, for example, the pages of The Justice System Journal, which began publication in 1974 under the auspices of the Institute for Court Management. Indeed, publications have addressed such previously unexplored topics as how to convert unused buildings into courthouses at one-half the cost of constructing new facilities. Greenberg, How a Connecticut County Converted a Supermarket into a Courthouse, 64 Judicature 290 (1981).

376 P. Carrington, D. Meador \& M. Rosengerg, Justice on Appeaz 105 (1976).

373 Id. at 104.

378 Id. at $103-20$. 
statute of limitations and other restrictions for federal habeas corpus actions. 379

I do not endorse these proposals. Indeed, this article has suggested making postconviction remedies more available than they are today to defendants who have pleaded guilty ${ }^{380}$ Nevertheless, if one assumes that criminal justice resources are as limited as the advocates of plea bargaining commonly contend, both the Carrington-Meador-Rosenberg and the Thompson-Bell proposals seem too timid.

Perhaps the costs of multiple postconviction proceedings are worth paying, but not in a system as reluctant to pay the costs of triál as ours. It is bizarre to afford some defendants unrestricted access to trial and appellate courts for repeated postconviction proceedings while pressing most defendants to sacrifice their initial opportunity to be heard. ${ }^{381} \mathrm{~A}$ better course would be to grant all defendants an unfettered right to trial (and perhaps to one appeal) and then to call a halt. If the issue is merely one of first things first, today's broad access to postconviction relief ought to be restricted in the interest of making trials more available.

4. Reduce the Size of Criminal Juries. The Supreme Court's decision in Williams $v$. Florida ${ }^{382}$ upholding the use of six-person juries in felony cases led to a flood of scholarly criticism. This criticism, based largely on sophisticated social science research, suggested both that six-person juries are less able than twelve-person juries to serve some traditional functions of the jury and that they are less advantageous to defendants. ${ }^{383}$ Although these conclusions occasionally have been questioned, ${ }^{384}$ the critics seemed correct on both points; they also were whistling in a wind tunnel.

One early, forceful criticism of Williams said much in its title, And Then There Were None. ${ }^{385}$ For the overwhelming majority of criminal defendants, however-those induced to plead guilty because American jurisdictions view themselves as too impoverished to implement the right to trial-there currently are none. To de-

378 Att'y General's Task Force on Violent Crime, Final Report 58-60 (1981).

sso See supra notes 161-62 and accompanying text.

${ }^{331}$ See The Supreme Court, supra note 4, at 38-39; Halberstam, supra note 17, at 42.

382399 U.S. 78 (1970).

s83 E.g., M. SAKS, JURY Verdicts (1977); Lempert, Uncovering "Nondiscernible Differences": Empirical Research and the Jury-Size Cases, 73 Mrch. L. REv. 643 (1975).

ss See Lermack, No Right Number? Social Science and the Jury-Size Cases, 54 N.Y.U. L. REv. 951, 967-72 (1979); Comment, The Impact of Jury Size on the Court System, Loy. L.A.L. REv. 1103 (1979).

${ }^{\text {sss }}$ Zeisel, . . . And Then There Were None: The Diminution of the Federal Jury, 38 U. ChI. L. REv. 710 (1971). 
bate the niceties of jury dynamics amidst the ruins of a system that strains to avoid using juries of any size is myopic. On the assumption that criminal justice resources will remain inadequate, the issue is not twelve versus six. It is twelve for a small number of defendants versus six for a larger number. ${ }^{386}$ Moreover, this issue of resource allocation does not seem extraordinarily difficult; although six jurors may not be as good as twelve, they are far better than none.

Despite Williams, the use of six-person juries in serious criminal cases remains aberrant. ${ }^{387}$ Our nation's insistence on the historic number twelve illustrates once more the taste for champagne and caviar that has brought our system of courtroom justice to the verge of starvation. ${ }^{388}$

5. Simplify Jury Selection Procedures. When viewed against the protestations of poverty used to rationalize American guilty plea rates, the waste caused by current jury selection procedures seems scandalous. ${ }^{389}$ An extreme example was the New Haven murder prosecution of Bobby Seale and Ericka Huggins in which the selection of a jury required the examination of more than 1000 prospective jurors over a four-month period. ${ }^{390}$

Half a century ago, the Wickersham Commission called for an

sse How many resources would be saved by a reduction in jury size is uncertain. Plainly a reduction from twelve jurors to six would save at least the time, salaries, and expenses of six jurors per case. If the customary criticisms of six-person juries are sound, see sources cited supra notes $383 \& 385$, this reduction also ought to cut deliberation time significantly and to reduce by about half the number of retrials necessitated by hung juries. A few jury management problems (for example, those arising when a single juror engages in misconduct during a trial) also would become less frequent. Some studies of civil proceedings, however, have indicated that a reduction in jury size might not limit notably the amount of time required for voir dire or for trial. See Beiser \& Varrin, Six-Member Juries in the Federal Courts, 58 Judicature 424, 428-31 (1975); Pabst, What Do Six-Member Juries Really Save?, 57 Judicature 6 passim (1973).

${ }^{287}$ See Nat'l Center for State Courts, Facets of the Jury System 41-43, 61-111 (1976).

${ }^{388}$ In Apodaca v. Oregon, 406 U.S. 404 (1972), the Supreme Court held nonunanimous verdicts constitutionally permissible in state criminal proceedings. Like reductions in jury size, nonunanimous verdicts probably diminish both jury deliberation time and the number of retrials following hung juries. Nevertheless, nonunanimous verdicts raise much more severe doubts about the accuracy of criminal convictions than the use of six-person juries. Zeisel, supra note 385, at 721-24. For this reason, departure from the traditional requirement of unanimity in serious criminal cases is probably undesirable.

sso For additional discussion of jury selection procedures, see supra notes $323-27$ and accompanying text.

380 See Seale Jury Seated After 4 Months of Questioning, N.Y. Times, Mar. 12, 1971, at $43, \mathrm{col}$. 3. In one Illinois murder case, only four jurors had been seated three months after voir dire began. Graham, Mud Slinging Stalls Prison Murder Trial, Am. Law., Jan. 1981, at 16, 16. 
end to attorney-conducted voir dire, ${ }^{391}$ and, largely within the past fifteen years, a number of courts have instituted this reform. ${ }^{392}$ Apart from questioning by the court rather than by counsel, some of these courts have employed written questionnaires to elicit information from prospective jurors, and some have used a single voir dire proceeding to select juries for more than one case. ${ }^{393}$

These reforms conserve significant resources, ${ }^{394}$ but they do not go far enough. The usual English practice of seating without inquiry the first twelve prospective jurors to enter the jury box may not merit duplication here, ${ }^{395}$ but we ought to come close. First, our use of peremptory challenges should be ended. The asserted justification for these challenges is that they promote impartial juries; but of course, whenever there is good reason to believe that a prospective juror is biased, he is not challenged peremptorily but instead is disqualified for cause. In exercising a peremptory challenge, a lawyer is invited to give rein to his whim or hunch-usually not a whim or hunch that a prospective juror is partisan or incompetent but merely that he is likely to prove less favorable to the lawyer's position than his replacement. Almost inevitably, challenges are exercised partly on the basis of race or things like race, and opposing advocates attack the panel of prospective jurors from both ends. The thin German Lutheran who rarely smiles disappears from this panel along with the black who wears his hair in an Afro. The tendency is to provide juries of clerks and to diminish our vision of the jury as a cross section of

381 Nat'l Comm'n on Law Observance \& Enforcement, Report on Criminal ProceDURE 47 (1931); see also Judicial Conference of the U.S., The Jury System in the Federal Courts, 26 F.R.D. 409, 424 (1960) (recommendation of the judicial conference committee on the operation of the jury system that attorney-conducted voir dire be eliminated in federal courts).

${ }^{392}$ See, e.g., FED. R. CRIM. P. 24(a); ILL. CT. R. 231, 244; N.J. CT. R. 1:8-3(a). As of 1971,20 states permitted or required some form of court-conducted voir dire. Levit, Nelson, Ball \& Chernick, Expediting Voir Dire: An Empirical Study, 44 S. Cal. L. REv. 916, 929 n.58 (1971).

${ }^{393}$ See Draheim, Efficient Jury Utilization Techniques . . Or Proposition 12, 28 Drake L. Rev. 21, 29-38 (1978-79).

${ }^{394}$ See Levit, Nelson, Ball \& Chernick, supra note 392, passim; Note, Judge Conducted Voir Dire as a Time-Saving Trial Technique, 2 Rut. CAM. L. Rev. 161 (1970).

sas Professor Hans Zeisel once asked the Chief Justice of England, Lord Parker of Waddington, "What if one of the jurors were a cousin of the defendant?" The Chief Justice replied, "Wouldn't that be awkward?" Zeisel \& Diamond, The Jury Selection in the Mitchell-Stans Conspiracy Trial, 1976 AM. B. Found. RESEARCH J. 151, 173 n.30. Although I am not convinced that the greater heterogeneity of American society justifies the use of more extensive voir dire proceedings here than in England, our failure to restrict prejudicial pretrial publicity in the English manner does necessitate a more extended voir dire in some cases. 


\section{the community. ${ }^{386}$}

Second, whether or not peremptory challenges are abolished, the initial voir dire of prospective jurors should consist of just three questions:

Are you acquainted with any of the parties, witnesses, or lawyers in this case? case?

Do you currently know anything about the facts of this

Do you know any reason at all why it might be difficult for you to render a verdict on the basis of the evidence presented in court in accordance with the court's instructions?

An affirmative answer to any of these questions would require further questioning, but a prospective juror who answered all three questions "no" ought to be seated without further inquiry (unless of course independent evidence of the sort that would merit the disqualification of a judge established grounds for his dismissal)..$^{397}$

${ }^{308}$ The Supreme Court has said that a jury must be "a body truly representative of the community," Smith v. Texas, 311 U.S. 128, 130 (1940), and that "the fair cross section requirement" is "fundamental to the jury trial guaranteed by the Sixth Amendment," Taylor v. Louisiana, 419 U.S. 522 (1975). The author of the Taylor opinion, Justice White, also wrote for the Court in Swain v. Alabama, 380 U.S. 202 (1965), a case holding that a prosecutor may use his peremptory challenges to exclude all blacks from a jury without violating the Constitution. Id. at 209-22. Apart from the question whether the all-white jury in Swain was "a body truly representative of the community," one wonders whether the prosecutor's discrimination was justified by a compelling governmental interest. The Court did not mention in Swain the heightened scrutiny to which racial classifications ordinarily are subject, and a compelling reason for acting on the basis of a prosecutor's whim or hunch is difficult to conceive.

397 This simplification of the jury selection process, when coupled with a reduction in the size of criminal juries, might maintain about the same "balance of advantage" between the state and the accused as present procedures have established. A reduction in jury size would diminish the likelihood of deadlock and, perhaps, favor the state in other ways as well, see the materials cited supra notes $383 \& 385$, but a simplification of jury selection procedures might yield an offsetting increase in the diversity of jury panels to the apparent benefit of the accused. Moreover, a reduction in jury size would diminish the likelihood that a "wildcard juror" (a juror who exhibited no bias but somehow seemed untrustworthy) might appear on the panel, and the use of peremptory challenges might therefore seem less important. To some extent, a reduction in jury size and a simplification of jury selection procedures would exhibit countervailing tendencies, but in one respect these reforms would be alike. Both would conserve resources that could be used to make the right to trial not just a right that defendants have but one that they get.

Sensible though it is, this proposal for a greatly simplified voir dire procedure might encounter constitutional difficulty in exceptional situations. In Ham v. South Carolina, 409 U.S. 524 (1973), a trial judge had asked prospective jurors about prejudice toward the defendant but had refused to ask specifically about racial prejudice. The Supreme Court held that the defendant, a black civil rights worker charged with marijuana possession, had been denied due process by the court's refusal to ask prospective jurors about their possible racial biases. 
This simplification of jury selection procedures might save more time and money than any of the other reforms suggested here. Unlike some of the other reforms, however, economy would not be the only virtue of this change. In addition, abolishing peremptory challenges and almost abolishing voir dire would promote the dignity and privacy of prospective jurors, further their equal treatment, and achieve more fully the asserted purposes of our jury system.

6. Simplify Evidentiary Rules. In the early nineteenth century, Jeremy Bentham decried "almost every rule that has ever been laid down on the subject of evidence" as "repugnant to the ends of justice." ${ }^{388}$ Bentham argued that evidence never should be excluded on the ground that its exclusion would promote accurate factfinding. ${ }^{389}$

Some of the common law rules that Bentham criticized-most notably, the rule disqualifying criminal defendants from testifying under oath at trial-now have been abandoned, and most other common law exclusionary rules have been liberalized as well. Nevertheless, the common law's system of proof remains essentially in-

If, as I believe, current jury selection procedures are outrageously prolonged, it is appropriate to ask with respect to every question propounded during voir dire whether the gains of asking it exceed the costs. The Supreme Court made clear in Ham that it had not discovered a due process right to an extended psychoanalytic probing of each prospective juror to ferret out subtle, hidden biases; instead, the defendant was entitled merely to have the court or counsel propound a single general question on racial prejudice to the panel. Id. at 527-28. The single question required by the Court was, however, essentially useless. I know very few people who would avow their racial bigotry in response to this question. I doubt, for example, that Lester Maddox, George Wallace, or Orville Faubus ever considered himself biased, and if any of them did; I am not sure that he would have conceded this fact in a public courtroom. If any prospective juror did admit to racial bias but pledged to judge the case fairly on the basis of the evidence presented in court, his extraordinary honesty on the first question might suggest his credibility on the second, and he might seem an exceptionally qualified juror. Moreover, if a prospective juror recognized some bias within himself-perhaps a bias that he was trying to overcome-he probably should not have been required to avow this problem publicly so long as he remained confident of his ability to judge the case fairly and in accordance with the court's instructions. The due process clause apparently does not require United States Supreme Court Justices or even South Carolina trial judges to answer rude questions about their personal prejudices when they hear cases involving black civil rights workers.

Three years after Ham, in Ristaino v. Ross, 424 U.S. 589 (1976), the Supreme Court held that the Constitution did not require voir dire inquiry concerning racial prejudice in a case in which black defendants were charged with robbing, assaulting, and attempting to murder a white security guard. Ham thus became something of a sport, and the case might not pose a significant barrier to the proposal in text for greatly simplified jury selection procedures. See also Rosales-Lopez v. United States, 451 U.S. 182 (1981) (plurality opinion) (specific inquiry into possible prejudice required only in "special circumstances").

$3981 \mathrm{~J}$. Bentham, Rationale of Judicial Evidence 4 (London 1827).

398 Id. at 1. 
tact-a circumstance that may reflect the self-interest of lawyers and their deep attachment to the familiar, for our rules of evidence make only a little more sense today than they did in 1800 .

Now that common law pleading and its specialized forms of action have been abandoned, our law's grandest living memorial to common law refinement is the hearsay rule and its exceptions. In 1980, the Supreme Court noted that the Federal Rules of Evidence list over twenty hearsay exceptions, ${ }^{400}$ while the number and nature of these exceptions vary significantly among the states. The Court observed that "every set of exceptions seems to fit an apt description offered more than 40 years ago: 'an old-fashioned crazy quilt made of patches cut from a group of paintings by cubists, futurists and realists." "401 Despite this declaration, the Supreme Court reiterated that the confrontation clause of the sixth amendment in large measure "constitutionalizes" the common law hearsay rule in criminal prosecutions. ${ }^{402}$

Jeremy Bentham favored the exclusion of hearsay evidence when more direct proof was available; when hearsay was the best proof to be had, however, he thought it worth hearing. ${ }^{403}$ Bentham's proposed liberalization of the hearsay rule has been endorsed by modern scholars ${ }^{404}$ and incorporated in the Model Code of Evidence. ${ }^{405}$ This revision apparently would be consistent with the results (although certainly not with the language) of the Supreme Court's confrontation clause decisions. ${ }^{408}$ Moreover, a reinterpretation of the confrontation clause to incorporate Benthamite principles has significant scholarly support, ${ }^{407}$ and of course the

100 Ohio v. Roberts, 448 U.S. 56 (1980). See FED. R. Evid. 803, 804.

101 Ohio v. Roberts, 448 U.S. 56, 62 (1980) (quoting Morgan \& Maguire, Looking Backward and Forward at Evidence, 50 HaRv. L. Rzv. 909, 921 (1937)).

102 Among other things, the Court said that "reliability can be inferred without more in a case where the evidence falls within a firmly rooted hearsay exception." 448 U.S. at 66 . Nevertheless, some firmly rooted hearsay exceptions-for example, the exception for declarations by co-conspirators-arè not grounded on the supposed reliability of the statements admitted into evidence.

403 J. BenthaM, supra note 398 , at 407-10.

sot See Chadbourn, Bentham and the Hearsay Rule-A Benthamic View of Rule 63(4)(c) of the Uniform Rules of Evidence, 75 HARv. L. REv. 932, 937 (1962); James, The Role of Hearsay in a Rational Scheme of Evidence, 34 ILL. L. REv. 788 (1940).

105 Model Code or Evidence Rule 503(a) (1942).

${ }^{108}$ See Westin, The Future of Confrontation, 77 Mich. L. Rev. 1185, 1195-96 (1979) (arguing that the Supreme Court has excluded hearsay evidence under the confrontation clause only when declarants were available to testify in court or when the government itself was responsible for their unavailability). But see Ohio v. Roberts, 448 U.S. 56, 64-65 (1980) (prosecution may introduce statements of unavailable witnesses only when the statements bear sufficient "indicia of reliability").

${ }^{107}$ See California v. Green, 399 U.S. 149, $172-89$ (1970) (Harlan, J., concurring); Westin, 
confrontation clause restricts only the presentation of evidence by the state. Despite the lack of symmetry, a state might permit defendants to offer hearsay evidence whenever better evidence could not be presented. Nevertheless, Bentham's proposal for simplifying and liberalizing the hearsay rule has nowhere been adopted.

To a somewhat lesser extent than the hearsay rule, our rules concerning evidence of a defendant's prior conduct, documentary evidence, and the format of testimony at trial fit the historical pattern of unnecessary common law complexity. Paradoxically, the exclusion of evidence pursuant to these rules generally makes trials longer, not shorter. Substantial revision of all of these rules would both expedite the administration of justice and further the ascertainment of truth.

7. Use Videotape Technology in Assembling and Presenting Trial Testimony. The hero of this last segment on trial reform is not Jeremy Bentham but James L. McCrystal, an Ohio judge who has pioneered use of the prerecorded videotape trial. As Judge McCrystal has described it, the process begins when lawyers assemble (at their convenience and that of one or more trial witnesses), start a video recorder, and swear one of the witnesses. The lawyers examine this witness as though they were before a jury, noting and perhaps arguing evidentiary objections on the videotape. A judge later reviews the tape, passes on the evidentiary objections, and edits from the tape whatever material he holds inadmissible. Finally, the edited tape is presented to a jury.

McCrystal and Young have identified some of the advantages of this procedure:

(1) the trial flows without interruptions from objections, bench conference, delays for witnesses, counsel's pauses, client conferences and chamber retreats; (2) maximum utilization of juror time is achieved; (3) the time required for a given trial is shortened considerably; (4) the trial can be scheduled, with certainty, for a specific day; (5) the witnesses can be presented in the desired order, obviating the need for adjustment to availability at the last moment; (6) the chance of mistrial is greatly reduced; (7) there is no need to recess for the preparation of instructions; (8) directed verdict motions are decided when the tapes are previewed and do not infringe on courtroom time; (9) opening statements should be more effective with knowledge of precisely what the evidence will show; (10) 
the judge need not be present during the viewing of the tape; (11) the presence of the lawyers is not required during the viewing of the tape; (12) it is possible for judge and counsel to conduct simultaneous trials; (13) trial preparation can be more effectively scheduled and the taping may be in the most convenient order of witness availability; (14) last-minute preparation is eliminated; (15) time is afforded for study of evidentiary questions; (16) testimony on location is facilitated; (17) elimination of live trial impediments give the jury a comprehensive related view of the entirety of the case; (18) the tape can serve as the transcript of proceedings on appeal; (19) retrial is facilitated; (20) extrajudicial judge influence through reaction to witnesses and comments to counsel is reduced; (21) the court need no longer resort to the fiction that a juror can disregard what he has heard in accordance with the judge's instructions. ${ }^{408}$

Of course one might fear that this form of trial would prove insufficiently awesome to witnesses and jurors and would fail to impress upon them the human significance of their responsibilities. ${ }^{409}$ Nevertheless, available evidence offers no support for this concern and in fact suggests that prerecorded trials probably yield some gain in juror attention, comprehension, and retention. ${ }^{\mathbf{1 1 0}}$ Plainly the time saving potential of this trial format is enormous, and the dangers of this technological innovation seem minimal when compared with the pitfalls of today's more widely employed expedient, plea bargaining. Like most of the other reforms suggested in this section, the prerecorded videotape trial would not

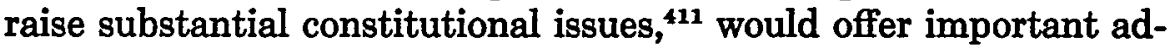

${ }^{108}$ McCrystal \& Young, Pre-Recorded Videotape Trials-An Ohio Innovation, 39 BrookLyN L. Rev. 560, 663-64 (1973); see also McCrystal, Videotaped Trials: A Primer, 61 JudrCATURE 250 (1978); McCrystal, Videotaped Trials: Relief for Congested Courts?, 49 DEN. L.J. 463 (1973); Note, Videotape Trials: Legal and Practical Implications, 9 Colum. J.L. \& Soc. Probs. 363 (1972).

Although 21 advantages might seem enough, Judge Marvin E. Frankel has noted two additional virtues of the prerecorded trial. First, it would circumscribe attorney stratagems like asking questions known to be dubious but intended for effect; second, it would permit time for judicial thought between witnesses and even during the testimony of a single witness. Frankel, supra note 348 , at 534.

${ }^{108}$ See Note, The Role of Videotape in the Criminal Court, 10 Surfolk U.L. REv. 1107, 1136 (1976).

¿10 For a discussion of jury reactions to videotape testimony, see generally Miller, Televised Trials-How Do Juries React?, 58 Judicaturs 242 (1974); Miller, Fontest \& Dahnke, Using Videotape in the Courtroom: A Four Year Test Pattern, 55 U. DET. J. URB. L. 655 (1978).

111 The sixth amendment confrontation clause has been read to guarantee a defendant 
vantages apart from its economizing effect, and would permit a significant reallocation of existing resources if Americans wished to end our regime of bargained justice.

\section{The Pittsburgh and Philadelphia Stories: Simplification of the Trial Process Through "Jury Waiver Bargaining"}

In suggesting a final alternative to plea bargaining-bargaining for a waiver of the right to jury trial rather than for a plea of guilty-this article again begins with description and moves to prescription. The thesis that simpler trial procedures lead to increased trial use and to reduced pressure for self-conviction is supported, not only by our history and by European experience, but also by the recent experience of two American jurisdictions. In Pennsylvania's two largest cities, criminal trials commonly have been conducted in an even simpler and more rapid fashion than on the European continent. Although neither jurisdiction has attempted to abolish plea bargaining, guilty plea rates have been low. In Philadelphia in 1965 , only $27 \%$ of all criminal convictions were by plea of guilty; ${ }^{412}$ guilty pleas accounted for $35 \%$ of Pittsburgh's criminal convictions in $1967 .^{413}$ These guilty plea rates were far lower than those of Chicago (87\%), ${ }^{414}$ Cleveland (95\%), ${ }^{415}$ Houston (92\%), ${ }^{416}$ Manhattan (97\%), ${ }^{417}$ Alameda County (88\%), ${ }^{418}$ San Francisco (87\%), ${ }^{\mathbf{4 1 9}}$ and indeed almost every other urban jurisdiction in America. ${ }^{420}$ These unusually low guilty plea rates were also far lower than those of the less populous areas of Pennsylva-

the qualified right to attend all phases of his trial, Lewis v. United States, 146 U.S. 370, 372 (1892), and the sixth amendment also guarantees the right to a public trial. U.S. ConsT. amend. VI. Some uses of video prerecording might raise close questions under these constitutional provisions, but any constitutional objection could be obviated by permitting both the defendant and the public to be present throughout the preparation, editing, and exhibition of the videotape.

412 Specter, Book Review, 76 YALE L.J. 604, 605 (1967).

415 Admin. Orfice of the Court, Court of Common Pleas of Allegheny County, 1966-67 Annual Report 16 (1967) [hereinafter cited as Allegheny County Report].

114 Unpublished statistic supplied by Carl Rolewick of the Administrative Office of the IIlinois Courts for the year 1967.

415 Estimated on the basis of unpublished statistics supplied by John L. Lavelle, Court Administrator of the Court of Common Pleas of Cuyahoga County for the year 1967.

416 Unpublished statistic supplied by R. J. Roman of the Clerk's Office, Harris County District Courts for the year 1967.

417 Admin. Bd. of the Judicial Conperence of the State of New York, Twelfth ANNUAL REPORT 419 (Table 12) (1967).

48 Cal. Dep't of Justice, Crime and Delinquency in California 1966, at 86 (1966).

410 Id.

420 See supra note 36. 
nia. In 1965, despite the very large number of criminal trials conducted in Philadelphia and Pittsburgh, $63 \%$ of the state's convictions were by guilty plea. ${ }^{421}$ Indeed, the guilty plea rates of Philadelphia and Pittsburgh were lower than those that the same two cities had experienced during the 1920's. At that time, guilty pleas accounted for $58 \%$ of Philadelphia's convictions ${ }^{\mathbf{4 2 2}}$ and for $74 \%$ of the convictions in Pittsburgh. ${ }^{128}$

Although today's guilty plea rates in Philadelphia and Pittsburgh do not approach those of most other jurisdictions, these rates have increased since the mid-1960's. In Philadelphia, the number of trials still greatly exceeds the number of guilty pleas, but guilty pleas now account for $48 \%$ of the cases that end in conviction. ${ }^{24}$ In Pittsburgh, the change has been more pronounced. By $1975,62 \%$ of that city's convictions were by guilty plea, ${ }^{425}$ and by $1979,77 \% .{ }^{426}$ In short, Pittsburgh's low guilty plea rates of the mid-1960's have more than doubled within a dozen years.

On two occasions approximately nine years apart-in 1968 and in 1977-I interviewed prosecutors, defense attorneys, trial judges, and other officials in Philadelphia and Pittsburgh. On both occasions, I also attended trials and plea negotiation sessions. Changes in the criminal justice systems of the two jurisdictions could be discerned in more than the official statistics, but before exploring these changes, the systems' operations at the time of my initial investigation should be described in greater detail. ${ }^{427}$

The relative lack of plea bargaining in Philadelphia and Pittsburgh plainly was not the product of an unusual commitment of resources to their criminal justice systems. A study by Professor Martin Levin ${ }^{428}$ reported that the Court of Common Pleas in Pittsburgh not only had the lowest guilty plea rate of the four felony

421 Commonwealth ex rel. Kerekes v. Maroney, $423 \mathrm{~Pa} .337,345$ n.5, 223 A.2d 699, 703 n.5 (1966).

422 Philadelphia Bar Ass'n, Report of the Crime Survey Commttge 404 (1926).

12s R. Moley, Politics and Criminal Prosecution 160 (1929).

424 Philadglphin Court of Common Pleas, 1979 annual Report 51 (1979). In Philadelphia, 1863 defendants pleaded guilty in 1979, and 3015 were tried (2699 at nonjury trials and 316 before juries). Of the defendants who were tried, 1995 were convicted and 1020 were acquitted. The acquittal rate was substantially higher at nonjury trials $(35 \%)$ than at jury trials (26\%). Id.

4ss Unpublished statistics supplied by Grenville Hayes of the Administrative Office of the Court of Common Pleas of Allegheny County.

426 Unpublished statistics supplied by Dennis Starrett of the Allegheny Regional Advisory Committee of the Pennsylvania Council.

427 Unless otherwise noted, the descriptions that follow derive from my interviews and observations.

128 Levin, Delay in Five Criminal Courts, 4. J. Legar STUP 83 (1975). 
courts studied; ${ }^{\mathbf{4 2 9}}$ it also had the heaviest caseload per judge. ${ }^{\mathbf{4 3 0}}$ The caseload per judge in Pittsburgh was, in fact, almost five times greater than it was in the District of Columbia and almost three times greater than it was Chicago.431 Although the caseload per judge was lighter in Philadelphia than in Pittsburgh, my very rough calculations suggest that it remained about twice as great as the criminal caseload in Chicago. ${ }^{\mathbf{4 3 2}}$

Similarly, the low rate of guilty pleas in these two jurisdictions did not reflect any unusual devotion of lawyers and court officials to jury trials. Not only were guilty plea rates unusually low; jury trial rates were low as well. In Philadelphia, only $1.7 \%$ of all criminal cases were tried to a jury, ${ }^{438}$ and in Pittsburgh the figure was 3\%. ${ }^{434}$ Professor Levin reported that the rate of what he called full length trials was substantially lower in Pittsburgh than in any other felony court that he studied. ${ }^{435}$ Moreover, in the United States as a whole, a significant majority of the felony cases resolved by trial in recent years have been resolved by juries; as a result, jury trials probably have occurred in about $8 \%$ of all cases filed in America's felony trial courts. ${ }^{436}$

In both Pittsburgh and Philadelphia, the most common procedure for resolving a felony case in the mid-1960's was a nonjury trial. In Pittsburgh in 1967, the cases of 3005 defendants were resolved at these trials (while 180 defendants were tried before juries, 1144 pleaded guilty, and 1174 had their cases dismissed). ${ }^{437}$ In Philadelphia in 1966, 13,750 criminal charges (a number substan-

420 Id. at 112 (Table 8).

430 Id. at 88 (Table 1).

481 Id.

48s According to unpublished material supplied by Edward Blake, Court Administrator of the Court of Common Pleas of Philadelphia [hereinafter cited as Philadelphia Statistics], 2777 "court days" were devoted to criminal matters in 1966 . On the assumption that a judge devotes approximately 215 days per year to judicial business (250 days per year, exclusive of weekends and holidays, less 35 days for vacations, illnesses, workshops, and the like), this figure suggests that the equivalent of about 13 full-time judges resolved the 12,308 cases that, according to the same unpublished materials, were completed during that year. (Two years later, at the time of my visit, there were indeed 13 judges sitting in the part of the Court of Common Pleas that heard criminal matters.) The average annual caseload per judge was therefore 947. Levin reported that the caseload per judge in Chicago was 450 . Levin, supra note 428, at 88 (Table 1). Nevertheless, one cannot be at all confident that these comparative caseload figures were computed on compatible bases; they are at best suggestive.

4ss Philadelphia Statistics, supra note 432.

4s. Allegheny County Report, supra note 413, at 16.

4ss Levin, supra note 428, at 88 (Table 1).

se See supra note 85.

4s7 Allegheny County Report, supra note 413, at 16. 
tially greater than the number of defendants) were resolved at nonjury trials (while 358 charges were resolved by jury verdicts, 4414 were resolved by guilty pleas, and 3094 ended in dismissal, abatement, or transfer). ${ }^{438}$ An obviously critical question is why prosecutors, defendants, and defense attorneys in these jurisdictions usually preferred nonjury trials to jury trials on the one hand and to bargained pleas of guilty on the other.

Defense attorneys in other jurisdictions often explain their preference for jury trials by emphasizing the supposed willingness of jurors to consider legally irrelevant equities and by noting that, in most states, the vote of one juror out of twelve is sufficient to prevent conviction. ${ }^{439}$ Some Pittsburgh defense attorneys agreed with this general perception that juries are less likely to convict than judges, but most did not. In Philadelphia, moreover, defense attorneys invariably maintained that judges were as likely, and perhaps more likely, to acquit than juries. ${ }^{40}$

The somewhat divergent views of defense attorneys in the two jurisdictions seemed to reflect somewhat divergent practices. Thomas M. Uhlman and N. Darlene Walker recently published two studies of felony prosecutions in a major eastern city, ${ }^{441}$ and

4ss Philadelphia Statistics, supra note 432.

439 Although nonunanimous jury verdicts are constitutionally permissible, Apodaca v. Oregon, 406 U.S. 404 (1972), every state except Louisiana and Oregon requires unanimous verdicts in felony cases. See Nat'l CentzR por State Courts, supra note 387, at $41-43$ (Chart A) (1976). Only three additional states permit nonunanimous verdicts in misdemeanor prosecutions absent the defendant's consent: Idaho, id. at 44,73, Oklahoma, id. at 97, and Texas, id. at 104. For information on each of the 50 states' provisions, see id. at 61111.

"10 Lawyers in both cities also suggested as a reason for waiving jury trials that judges were more predictable. One commented that it was "like having a standing jury."

Professor Stephen J. Schulhofer recently completed a study of plea and "waiver" bargaining in Philadelphia. S. Schulhofer, supra note 52. On most points, Schulhofer's description of Philadelphia practices in 1982 differed little from my description of earlier practices. In one respect, however, things appear to have changed. The public defenders with whom Schulhofer and his student assistants spoke regarded juries as more likely to acquit than judges in most cases. Id. at 89. To some extent, this apparent change in the perceptions of practitioners might have reflected a change in practice. The acquittal rate at nonjury trials had declined from $40.2 \%$ in the period from mid-1968 though mid-1974, see infra note 443 and accompanying text, to $31.6 \%$ during 1981 . S. Schulhofer, supra note 52, at n.137. Although the acquittal rate at nonjury trials remained higher at the time of Schulhofer's study than the acquittal rate at jury trials (31.6\% versus $27.5 \%$ ), public defenders claimed that these comparisons were misleading because the defenders were "likely to elect jury trial in very serious cases in which the prospects for acquittal [were] remote." Id.

"11 Uhlman \& Walker, "He Takes Some of My Time; I Take Some of His": An Analysis of Judicial Sentencing Patterns in Jury Cases, 14 LAw \& Soc'y Rev. 323 (1980) [hereinafter cited as He Takes Some of My Time]; Uhlman \& Walker, A Plea Is No Bargain: The Impact of Case Disposition on Sentencing, 60 Soc. Scr. Q. 218 (1979) [hereinafter cited as A Plea Is No Bargain]. 
although they did not identify the jurisdiction that they studied, the distinctive features of Philadelphia's judicial system could be recognized as easily as the silhouette of its Independence Hall. ${ }^{442}$ The authors reported that $40.2 \%$ of the defendants tried at nonjury. proceedings between mid-1968 and mid-1974 in this jurisdiction were acquitted ${ }^{44}$ - a figure that is much higher than the approximate $25 \%$ acquittal rate for American felony trials generally ${ }^{44}$ also significantly higher than the $34.2 \%$ acquittal rate for jury trials in that city. ${ }^{445}$ In Pittsburgh, by contrast, $33.7 \%$ of

442 Indeed, one who knew nothing of Philadelphia's judicial system easily might have recognized that city. There were not many northeastern cities in 1979 that had populations of two million and conservative, Democratic mayors. See T. UhLMaN, Racial Justice 27-32 (describing "Metro City").

When researchers have obtained information by promising not to reveal the identity of the jurisdiction studied, a reader who is confident that he recognizes the city behind the pseudonym may confront an ethical issue in deciding whether to reveal it. In this instance and a few others, however, I have not hesitated to blow the whistle. Obviously I was not a party to the authors' promises, and the gains of revealing this information seem to exceed the costs. Conceivably this action could diminish the willingness of potential sources to rely on similar promises and to share information in the future. Nevertheless, a source who relies on this sort of promise seems likely to be misguided. When researchers supply sufficient clues that an academic reader can identify the jurisdiction in question, knowledgeable local readers are likely to have even less difficulty. Moreover, many local observers are likely to have had contact with the researchers, and whenever the researchers' findings are interesting enough to matter, the word does get around. A promise of jurisdictional anonymity therefore does not do much to prevent local embarrassment-the kind that is most likely to concern local officials. At the same time, knowledge of the identity of the jurisdiction studied greatly increases the utility of the information presented. For example, piercing the veil of the Uhlman-Walker studies has enabled me to offer statistical data in support of conclusions about Philadelphia's criminal justice system that otherwise would have rested entirely on my own impressionistic observations and interview material. Moreover, my independently gathered knowledge of Philadelphia criminal justice has enabled me to offer some criticism of the conclusions that Uhlman and Walker advanced. This kind of interchange-both the criticism and the reinforcement-becomes impossible when one set of researchers can effectively keep secret the fact that they have studied the same jurisdiction as other researchers.

Although sources sometimes may insist on promises of jurisdictional anonymity as a condition of revealing information, I suspect that some researchers make these promises too freely. Some, in fact, seem to believe that these promises should be made routinely, perhaps to preserve the researchers' lofty image as social scientists unconcerned with localism and the helter skelter of politics. See M. FEeLEY, supra note 100, at xxii (discussing criticism that the author incurred for revealing the identity of the court that he examined while preserving the anonymity of individual sources). This view seems short-sighted and inconsistent with the openness that generally should characterize academic research. There have been too many books and articles about Metro City, Metropolitan Court, and Westville and not enough about places on the map.

44s He Takes Some of My Time, supra note 441, at 326; A Plea Is No Bargain, supra note 441, at 221. For some caveats concerning the $40.2 \%$ acquittal rate, see infra note 479 .

44 K. Brosi, supra note 49 , at 49.

${ }^{415}$ He Takes Some of My Time, supra note 441, at 326; A Plea Is No Bargain, supra note 441 , at 222 . 
the defendants tried without juries in 1967 were acquitted-again an unusually high figure, but not as high as the remarkable $48.9 \%$ acquittal rate at Pittsburgh jury trials. ${ }^{46}$

Far more important than acquittal rates in explaining the predominance of nonjury trials in Philadelphia and Pittsburgh were the sentencing patterns that characterized both cities. Judges, prosecutors, and defense attorneys uniformly agreed that a defendant convicted at a jury trial was likely to receive a substantially more severe sentence than a comparable defendant convicted at what they called a waiver trial. This phenomenon was in part the product of the sentencing philosophies of individual judges, but it also grew out of the practice of assigning judges with relatively "tough" reputations to the courtrooms in which jury trials were heard. ${ }^{477}$ Pittsburgh made extensive use of visiting judges, and these judges, generally assumed to have the sterner attitudes associated with rural and small-city areas, were assigned regularly to "jury rooms." 4 Although Philadelphia made much less use of visiting judges, its assignments of local judges also strongly encouraged waivers of the right to jury trial. ${ }^{449}$

Indeed, the agreement to waive a jury was occasionally the product of express bargaining. I observed a number of "major case" bargaining sessions in Philadelphia in which defense attorneys proposed waivers of the right to jury trial in exchange for a reduction of the charges against their clients. ${ }^{450}$ Moreover, when defense attorneys suggested that their clients would waive the right to jury trial in exchange for the assignment of their cases to particular judges, presiding judges and court administrators often were accommodating. ${ }^{\text {s1 }}$ In short, Philadelphia and Pittsburgh discouraged exercise of the right to jury trial in more or less the same fashion as other cities by rewarding defendants who waived this right and by threatening defendants who exercised it with unusually severe sentences. What was distinctive about Philadelphia and Pittsburgh was simply that no one in these cities regarded plea bargaining as the principal alternative to jury trials.

Just as sentencing patterns explained the relative absence of

140 Allgaheny County Repont, supra note 413, at 16.

147 He Takes Some of My Time, supra note 441, at 326-27.

148 See Levin, supra note 428, at 119.

44. See C. Silbrrman, Criminal Violence, Criminal Justice 279-80 (1978).

4so I did not, however, see any case in which this offer was accepted.

431 "Expediting the business of the court is what we're here for," one of Philadelphia's Deputy Administrators for Criminal Listings observed. Interview with Albert A. Ciardi Jr., in Philadelphia (Jan. 16, 1968). 
jury trials in Philadelphia and Pittsburgh, they also provided the most obvious explanation for the lack of guilty pleas. ${ }^{42}$ Without exception, judges, prosecutors, and defense attorneys reported that a defendant ordinarily could not anticipate a notably lighter sentence following a guilty plea than he would have received following conviction at a nonjury trial. The only disagreement concerned whether there might be a slight "sentence differential" between defendants convicted by plea and those convicted at nonjury trials, or whether the two procedures usually led to identical sentencing outcomes. Indeed, most observers, including most of the defense attorneys, adhered to the latter view. ${ }^{453}$ In most American jurisdictions, a defendant apparently can anticipate both a more severe sentence if convicted by a jury than if convicted by the court and a more severe sentence if convicted by the court than if convicted on a plea of guilty. ${ }^{454}$ In Philadelphia and Pittsburgh, however, the usual three tiers of the sentence differential had been collapsed into two, and only defendants convicted at jury trials were routinely penalized for their tactical decisions.

The Uhlman-Walker studies revealed that, at least in Philadelphia, the practitioners' perceptions of sentencing patterns were accurate. Using a concept of sentence weights that enabled them to compare prison and probationary sentences in terms of severity, the authors reported that the mean sentences imposed following guilty pleas and following convictions at nonjury trials were essentially the same-a weight of 24.9 for guilty plea convictions and 25.1 for convictions at nonjury trials. ${ }^{458}$ The average sentence im-

452 In Pittsburgh, but not in Philadelphia, an additional reason for the relative lack of plea bargaining may have been what Professors James Eisenstein and Herbert Jacob would call the instability of courtroom work groups. See J. EISENSTEIN \& H. JACOB, FeLONY Justice 35-37 (1977). Lawyers in both Pittsburgh and Philadelphia, however, explained the principal organizational obstacle to plea bargaining not in terms of the ways in which lawyers and other personnel were assigned to particular courtrooms, but rather in terms of the ways in which cases were allocated to these courtrooms. Because of last-minute case assignments, defense attorneys usually did not know which prosecutor would be responsible for a given case until the day on which the case was set for trial. With the exception of homicide cases in Pittsburgh and cases designated major cases by the prosecutor's office in Philadelphia, the only opportunity for plea negotiation was usually a rushed conference in the courtroom or in chambers shortly before the case was to be tried and after the attorneys were as ready to try it as they would ever be.

4ss See S. Schulhofer, supra note 52, at 76-81 (six Philadelphia public defenders believed that a guilty plea generally led to some break in sentencing; eight public defenders believed that guilty plea defendants generally received no break).

454 See, e.g., Cook, Sentencing Behavior of Federal Judges: Draft Cases 1972, 42 U.

CIN. L. REv. 597 (1973); Oster \& Simon, supra note 368, at 4.

${ }^{435} \mathrm{He}$ Takes Some of My Time, supra note 441, at 328. 
posed following convictions at jury trials, by contrast, was $63.1 .{ }^{486}$ Defendants who pleaded guilty were somewhat less likely to be imprisoned than defendants convicted at nonjury trials (34\% versus $39 \%$ ), but neither group was nearly as likely to be imprisoned as the defendants convicted by juries $(87 \%) .^{457}$ In fact, defendants convicted at nonjury trials were slightly less likely to have been convicted of the most serious charge filed against them than defendants who had pleaded guilty. ${ }^{458}$

To some extent, more severe sentences were imposed following jury trials in Philadelphia because jury trials occurred more often in serious cases, but even when Uhlman and Walker controlled for the seriousness of the offense charged and for other "criminality factors," they found that the sentences imposed after guilty pleas and nonjury trials were almost identical, while the sentences imposed following jury verdicts were about twice as severe. ${ }^{458}$ They also reported that the defendant's bail status, type of defense counsel, age, race, and sex did not alter the basic relationship between method of conviction and sentencing outcome. ${ }^{\mathbf{4 0}}$

In light of these sentencing patterns, the significant question may seem to be, not why so many defendants preferred nonjury trials, but why significant numbers of defendants pleaded guilty. Although Uhlman and Walker discussed this issue, ${ }^{461}$ they overlooked one reasonably obvious explanation-that apart from any possibility of securing sentencing concessions, a substantial number of defendants recognized that they had no plausible defenses. Many of these defendants may have had no desire to undergo even very rapid trials when the outcomes seemed inevitable. ${ }^{462}$ To be sure, some manifestly guilty defendants in both cities did insist on trials simply in the hope that prosecutorial errors might lead to acquittals. Nevertheless, despite the relatively casual trial practices that characterized these jurisdictions, ${ }^{463}$ there were undoubtedly cases in which this hope seemed unrealistic and others in which it seemed so slim as not to be worth even the emotional burdens of

4s8 $I d$.

457 Id.; A Plea is No Bargain, supra note 441, at 225 (Table 1).

4ss A Plea Is No Bargain, supra note 441, at 224.

6s Id. at 227 (Table 2); He Takes Some of My Time, supra note 441, at 333 (Table 2).

«co A Plea Is No Bargain, supra note 441, at 331 n.14, 332-33 (Table 2).

181 Id. at 331-33.

163 See supra notes 73-78 and accompanying text; accord S. Schulhofer, supra note 52, at 84-86 (62\% of guilty pleas in Philadelphia apparently entered without significant sentencing concessions).

4es See infra notes $482-90$ and accompanying text. 
trial. Prosecutors and defense attorneys described a substantial portion of guilty pleas in both cities as "open pleas." These pleas were entered without an express bargain and usually with little reason to anticipate an implicit reward.

In addition, there were some cases in Philadelphia and Pittsburgh in which defendants properly could view bargained guilty pleas as bargains. The slight indications in the Uhlman-Walker figures of a "sentence differential" between defendants who pleaded guilty and those convicted at nonjury trials may have reflected these atypical cases rather than some small sentence differential applicable to all or most prosecutions. In homicide cases in Pittsburgh and in homicide and other "major cases" in Philadelphia, prosecutors recognized that trials of any description were likely to consume substantial resources, and they often were willing to bargain for guilty pleas in these cases. ${ }^{464}$ Indeed, apart from the fact that nonjury trials were a frequently discussed option, plea negotiation in these "major" cases resembled plea negotiation elsewhere. Certainly when a prosecutor offered to reduce a first degree murder charge to second degree murder or to manslaughter in exchange for a plea of guilty, a defendant could sense that he had, in effect, been offered a significant sentencing concession (especially in view of the mandatory minimum life sentence prescribed for first degree murder in Pennsylvania). ${ }^{466}$

Moreover, when prosecutors in less serious cases recognized that they might be unable to obtain convictions at trial, they frequently offered significant concessions in an effort to secure pleas of guilty. ${ }^{466}$ In the overwhelming majority of these "weak" cases, the offer to a defendant who had secured his pretrial release was a recommendation of probation; and although the recommended sentence for a defendant in custody sometimes involved jail time, it was almost invariably time already served. ${ }^{467}$ Defendants who sensed even a slight possibility of conviction at trial usually found the prosecutors' offers irresistible. ${ }^{488}$ Although prosecutors ordinarily seemed to have little interest in inducing defendants to plead guilty, these weak cases and some major cases were plainly exceptions. It is therefore not surprising that, in the aggregate, the

104 See The Prosecutor's Role, supra note 4, at 61-62.

${ }^{163} 18$ PA. Cons. Stat. Ann. § 1102(a) (Purdon 1973 \& Supp. 1981); see Zimring, Eigen \& O'Malley, Punishing Homicide in Philadelphia: Perspectives on the Death Penalty, 43

U. CHI. L. REv. 227, 233 \& n.10 (1976).

168 See The Prosecutor's Role, supra note 4, at 62.

467 See id.

16s See id. 
Uhlman-Walker figures revealed a slightly lower likelihood of imprisonment for defendants who pleaded guilty than for those convicted at nonjury trials. Contrary to the suggestion of the authors themselves, ${ }^{169}$ the entry of guilty pleas in Philadelphia probably did not reflect a significant misperception of sentencing patterns on the part of most defense attorneys.

Because plea bargaining and implicit "waiver" bargaining induced the overwhelming majority of criminal defendants in Pittsburgh and Philadelphia to relinquish the right to jury trial, some observers concluded that these cities' practices were not very different from those of other jurisdictions. Charles E. Silberman wrote of Philadelphia:

During his tenure as district attorney (1969-73 [sic $\left.\left.{ }^{40}\right]\right)$, Arlen Specter gained national acclaim for having abolished plea bargaining. The reputation was undeserved; all that Specter did was shift its locus. Instead of bargaining over the charge to which defendants would plead guilty, prosecutors and defense lawyers under Specter's regime did their bargaining over whether or not defendants would waive their right to a jury trial and elect a bench trial instead. Since bench trials can be completed in a matter of minutes, they serve substantially the same purpose as guilty pleas; in some jurisdictions, a bench trial . . . is referred to as "a slow plea of guilty." . . . In short, plea bargaining was abolished in name only. ${ }^{411}$

As this article has indicated, Philadelphia did not abolish plea bargaining even in name, and so far as I am aware, Arlen Specter did not suggest that it had. Specter maintained only that there was much less plea bargaining in Philadelphia than there was elsewhere, and this contention was accurate. ${ }^{472}$ Moreover, Specter did not claim to have brought about this phenomenon, which clearly antedated his term as district attorney. ${ }^{43}$ The significant issue raised by Silberman's discussion, however, is the extent to which nonjury trials in Philadelphia and Pittsburgh should be regarded as the functional equivalent of pleas of guilty in other jurisdictions.

On occasion, as Silberman indicated, nonjury trials in Philadelphia, Pittsburgh, and elsewhere were called "slow pleas of

\footnotetext{
46" A Plea Is No Bargain, supra note 441, at 232.

470 The dates should be 1966 to 1973.

471 C. Strberman, supra note 449 , at $279-80$ (footnote omitted).

472 See Specter, supra note 412 , at 605.

48 See id.
} 
guilty." ate. In a very few cases, in fact, defense attorneys entered explicit "slow plea bargains." A Philadelphia defense attorney reported that he might approach a trial judge in chambers and say, "Your Honor, my client is crazy. They've got him dead-to-rights, but he still says that he didn't do it. Let's give him a half hour trial just to make him happy, but when you find him guilty, give him no more than two years, O.K.?" The attorney added that the judge was likely to respond to this disloyal proposal by accepting it or else by haggling about the terms of the defendant's mock trial. ${ }^{475}$

Although concerted efforts to deceive defendants in this fashion were certainly exceptional, most defense attorneys in Philadelphia and Pittsburgh observed that these cities' sentencing practices permitted them to take hopeless cases to trial without much fear of reprisal when defendants were unwilling for one reason or another to plead guilty. Indeed, in some "slow plea" situations, the defendants themselves entertained no hope that their trials would lead to acquittals. Their attorneys sometimes preferred nonjury trials for other tactical reasons-for example, to obtain an opportunity to emphasize some mitigating circumstance that might not have been developed fully in a presentence report or to preserve the defendant's right to appeal a trial judge's unfavorable ruling on a pretrial motion. ${ }^{478}$ On other occasions, defendants who recognized that they would undoubtedly be convicted at trial simply found it psychologically difficult or impossible to convict themselves. ${ }^{47}$

In the overwhelming majority of cases resolved by nonjury trials, however, the term "slow plea of guilty" was a misnomer. ${ }^{48}$ Judges in Pittsburgh and Philadelphia did consider the evidence presented at these trials, and they were not reluctant to acquit when this evidence failed to establish guilt beyond a reasonable

47 The chief public defender in Pittsburgh even recalled an occasion when a trial judge had employed this description in court in the presence of a defendant-one whom the judge was about to try without a jury. Interview with George H. Ross, Public Defender, in Pittsburgh (Jan. 17, 1968).

475 The Defense Attorney's Role, supra note 4, at 1288.

${ }^{476}$ A guilty plea ordinarily precludes a defendant from challenging the denial of a pretrial motion on appeal or in postconviction proceedings. See, e.g., McMann v. Richardson, 397 U.S. 759, 766 (1970). A "slow plea," however, does not. See Lefkowitz v. Newsome, 420 U.S. 283, 290-91 n.7 (1975).

177 See The Changing Debate, supra note 4, at 666-67.

${ }^{178}$ Professor Schulhofer and four student assistants observed 182 nonjury trials in Philadelphia in 1982. They concluded that only "six trials might be considered candidates for the 'slow plea' designation." S. Schulhofer, supra note 52, at 126. 
doubt. As this article has noted, the acquittal rates at nonjury trials in these cities substantially exceeded the acquittal rates in most other American jurisdictions, and it is therefore nonsensical to dismiss these proceedings as the functional equivalent of pleas of guilty. ${ }^{479}$ Although bargaining for waivers of the right to jury trial seemed as common in these cities as elsewhere, the difference between inducing a defendant to select a particular form of trial and inducing him to forgo any trial whatever is a distinction of considerable importance. It is the difference between affording the defendant an unfettered opportunity to present a defense and pressing him to sacrifice the opportunity to be heard. From a social perspective, it is also the difference between seriously attempting to determine what happened and merely splitting the difference.

The term "slow plea of guilty" as applied to nonjury trials in Philadelphia and Pittsburgh was a misnomer in another respect as well, for there was nothing "slow" about these proceedings. Indeed, the usual failure of prosecutors and trial judges to seek pleas of guilty reflected their recognition that a nonjury trial often consumed fewer resources than the process of negotiating a guilty plea and of making the record that would justify its acceptance in the courtroom. ${ }^{480}$ In one sense, Silberman was correct in suggesting that nonjury trials could "serve substantially the same purpose as guilty pleas";:481 although the nonjury trials of Philadelphia and Pittsburgh afforded defendants a much greater opportunity to be heard than the plea negotiation practices of other jurisdictions, these informal trials were about equally effective in enabling the

479 Professor Schulhofer has expressed some doubt about the $40.2 \%$ acquittal rate reported by Uhlman and Walker for Philadelphia nonjury trials. See supra note 443 and accompanying text. He has suggested that "some acquittals may have been recorded for cases in which the defendant was convicted on other related charges." S. Schulhofer, supra note 52, at n.167. Moreover, just as some of the recorded convictions may have been "slow pleas," some of the recorded acquittals may have been "slow dismissals." Schulhofer has reported, however, that recent statistics showing a $30 \%$ acquittal rate are not suspect on these grounds (although the $30 \%$ figure still may include a few "slow dismissals"). Id. Whether the appropriate figure is $40 \%, 30 \%$, or even less, the essential point seems beyond dispute: a great many nonjury trials in Philadelphia lead to acquittals after bona fide assessments of the evidence by trial judges; Philadelphia's adjudicative system cannot be equated with the nonadjudicative systems of other American jurisdictions.

600 The nonjury trials that Professor Schulhofer and his student assistants examined in 1982 were more carefully conducted and more structured than those that I had examined in 1968. Nevertheless, Schulhofer reported that the average length of a nonjury trial in Philadelphia was only about 45 minutes. When an allowance for courtroom waiting time was added to this figure, "the total courtroom time consumed for the average list room bench trial totalled approximately 1 hour and 20 minutes, compared to 55 minutes total courtroom time for the average guilty plea." S. Schulhofer, supra note 52, at 101-02.

s81 See supra note 471 and accompanying text. 
criminal justice system to handle large numbers of cases with resources that would have been inadequate to implement the right to jury trial.

Most lawyers and judges in Philadelphia and Pittsburgh estimated that a majority of nonjury trials were completed in less than an hour and that a single court could conduct eight to twelve of these trials in a day. ${ }^{482}$ Indeed, I sometimes heard suggestions of greater dispatch. George $H$. Ross, the chief public defender in Pittsburgh, maintained that fifteen-minute trials were common and that a judge might hear twenty or perhaps even twenty-five cases in a day. This sort of expedition would exceed that of the Old Bailey in the eighteenth century, and even the more moderate estimates would make today's criminal trials on the European continent appear extraordinarily deliberative. When I expressed some doubt about these estimates, James G. Dunn, the first assistant district attorney in Pittsburgh, produced-seemingly at random - an official summary of court actions on a day shortly before my visit. It revealed that a single judge on a single Monday had conducted nineteen trials. More generally, the cases of 3005 defendants were resolved at nonjury trials in Pittsburgh in 1967483 -a time when there were only three "waiver courtrooms" in that jurisdiction. Apparently each judge assigned to one of these courtrooms tried an average of approximately four and one-half cases on each working day (while receiving a substantial number of guilty pleas and conducting other judicial business as well). ${ }^{484}$

Philadelphia's nonjury trials included some extraordinarily expeditious proceedings in which the defendants' trial rights were sharply curtailed; a small number of cases were included in a program called officially the Minor Case Program and much more commonly referred to as "crash" court, "trash" court, or "trash and crash" court. (A footnote to this article describes the operation of this unique Philadelphia institution.) ${ }^{485}$ Of course, even with

${ }^{482} C f$. Levin, supra note 428 , at 85 n.5 (most "brief informal trials" are completed in 10 to 30 minutes).

48s See supra note 437 and accompanying text.

484 Based on a figure of approximately 215 days per year devoted to judicial business. See supra note 432 . In Chicago, by contrast, where guilty pleas accounted for about $80 \%$ of all convictions in the Criminal Division during 1972 and 1973, judges averaged about one disposition per day during the same years. See supra note 369 .

485 The district attorney's office determined whether to list a case in the "crash" program, and although a defendant could refuse to participate by demanding either a jury trial or an orthodox nonjury trial, a defendant who accepted the prosecutor's listing was required to stipulate both to the truth and to the admissibility of the police offense report. When an assistant district attorney first described this program to me, I suggested that agreeing to 


\section{these "crash" court cases set aside, the nonjury trials of Philadel-}

the truth of a police offense report was probably an almost certain route to conviction. To the contrary, the assistant replied, a majority of the defendants tried in the "crash" program were acquitted. Interview with Joseph M. Smith, Ass't District Att'y, in Philadelphia (Jan. $16,1968)$. Some acquittals in the relatively minor cases included in this program may have been the product of judicial sympathy rather than of bona fide doubt concerning the defendants' guilt, but lawyers insisted that an equal or greater number of acquittals were based on the "evidence." Although a defendant could not "contradict" the police offense report, he could "explain" and "supplement" it, and both the defendants' explanations and the frequent defects of the reports themselves commonly made guilt seem doubtful. In addition, defense attorneys maintained that, on occasion, they could "wiggle around" thejr stipulations and challenge portions of the police offense report.

Prosecutors reported that only about $10 \%$ of the criminal cases in the Court of Common Pleas were included in the "crash" program. The prosecutors added that they always examined the defendant's prior record before listing a case in the program, that gambling and liquor violations accounted for a very high proportion of cases in "crash" court, and that cases in which violence was alleged were ineligible for inclusion. Defense attorneys, however, maintained that assault cases were often tried in "crash" court; that in an effort to avoid the presence of police witnesses who might criticize lenient dispositions, even cases of assault on police officers were listed in the program; and that defendants with extensive prior records often appeared in "crash" court as well.

Defense attorneys also reported that defendants virtually never objected to "crash" court listings. The principal reason, they observed, was that the presiding judge deliberately assigned judges to "crash" court trials who were even more lenient than those assigned to other nonjury trials. When defendants were not simply acquitted, most of them were satisfied with their sentences.

Some attorneys also maintained that the district attorney's office had entered a standing agreement that any defendant sentenced to incarceration following a "crash" court proceeding could obtain a new trial free of "crash" court restrictions. Moreover, they expressed their confidence that, apart from this agreement, the "crash" court procedures were so constitutionally defective that any "crash" court conviction could be upset on appeal. Other defense attorneys reported that although the district attorney's office once had adhered to the described agreement, it had rescinded this understanding. Prosecutors, however, maintained that the supposed agreement had never been entered and was always a figment of some defense attorneys' imaginations. They also insisted that there were no legal defects in "crash" court proceedings and that their office was ready to submit the issue to an appellate court whenever a defendant sought review. (The fact that no defendant apparently had appealed a "crash" court conviction may suggest either that prosecutors did circumvent appeals by agreeing to new trials or, more probably, that the program's outcomes were fully as lenient as the defense attorneys suggested.)

Of course the "crash" court procedures may seem shocking, but as limited as a defendant's trial options were in "crash" court, these options were at least somewhat greater than those that the defendant would have enjoyed following a bargained plea of guilty. Indeed, it is difficult to conceive of any legal principle that would uphold bargained guilty pleas but condemn Philadelphia's somewhat more limited "crash" court waivers.

In practice, prosecutors did not defend "crash" court procedures on the ground that they were somewhat less restrictive of constitutional rights than is plea bargaining. An assistant district attorney, who said that he could not begin to justify his office's official position that the results of "crash" court trials were comparable to those of more elaborate nonjury proceedings, also maintained that plea bargaining would not increase significantly if the "crash" court were abolished. Instead, he said, the overwhelming majority of cases that formerly would have been "listed" in this court simply would not be prosecuted. For that reason, he declined to characterize Philadelphia's "crash" court as a substitute for plea bar- 
phia and Pittsburgh consumed far fewer resources than jury trials. The jury selection process, which typically requires half a day of even the simplest trial, ${ }^{486}$ was obviously unnecessary, and there was also no need to propose, discuss, and deliver sets of jury instructions. Moreover, with rare exceptions, both opening statements and summations were omitted.

Perhaps most significantly, the rules of evidence were generally disregarded at nonjury trials. Witnesses, in fact, were commonly invited to present their testimony in narrative form. Despite occasional departures from this pattern, prosecutors and defense attorneys apparently shared a tacit understanding that they would invoke evidentiary restrictions only when a witness's testimony threatened either to go far afield or to reveal information that plainly would be prejudicial.

Moreover, lawyers sometimes seemed so ill-prepared for trial that they might have had difficulty examining their witnesses in accordance with traditional standards. In Philadelphia, the prosecutor's office designated all prosecutions either as "major" or as "list room" cases, and the express criterion for placing a case in one category or the other was whether the prosecutor who would try it ought to interview his witnesses before presenting their testimony on the stand. In the overwhelming majority of cases (perhaps as many as ninety percent), prosecutors decided that this advance preparation was unnecessary and that the "list room" designation was appropriate. In Pittsburgh, moreover, the prosecutor's office was even less insistent on pretrial preparation; all cases except homicide cases were treated in the same manner as "list room" cases in Philadelphia. ${ }^{487}$

I observed some proceedings in which it seemed likely that the prosecutor not only had failed to interview his witnesses but also had failed to review his file before trial. ${ }^{48}$ A prosecutor typically opened his case by calling a police officer to the stand, by searching through his file for a police offense report, by asking, "Officer, did

gaining. Interview with Alan J. Davis, Ass't District Att'y, in Philadelphia (Jan. 16, 1968). ${ }^{486}$ See supra notes 323-27, 389-96 and accompanying text.

487 A little more than one week before my visit to Pittsburgh in 1968, the district attorney's office had adopted a new case assignment system that would have permitted the advance preparation of cases other than homicide cases, but no one had yet had any significant experience with this system.

188 In one, both the prosecutor and his principal witness seemed baffled as the prosecutor asked a number of questions about sexual fondling without eliciting incriminating information; the prosecutor apparently learned the nature of the charge against the defendant only when the witness impatiently answered one of his questions, "My private parts are no part of this case. That guy hit me' in the face with a bottle!" 
you have occasion to be in the vicinity of 2001 Brandywine at approximately 3:27 P.M. on June 29?," and then by inviting narrative testimony: "Will you tell us in your own words what happened?"

Although the informality that characterized nonjury trials in Philadelphia and Pittsburgh was sometimes troublesome, ${ }^{489}$ it often seemed refreshing. From my perspective, the practice of permitting defendants to tell their stories without interruption was especially attractive. Some defendants-in proceedings that certainly qualified as "slow pleas"-failed even to deny the charges against them. They merely described their troubled lives and motivations to the court, and their departure from legally relevant issues prompted no one in the courtroom to sound an alarm. Defendants often seemed to experience a sense both of gratitude and of gratification when their testimony was concluded, and although plea negotiation has been praised because it enables defendants to participate in the determination of their sentences, ${ }^{400}$ this bargaining process usually occurs in a closed door conference between two lawyers, effectively resolving a defendant's case in his absence. The informal trial processes of Pittsburgh and Philadelphia seemed to me to promote participation values more effectively.

The nonjury trials that differentiated Pennsylvania's two largest cities from other jurisdictions in the mid-1960's were plainly far from perfect. Like other urban jurisdictions, these cities paid a substantial price for the inadequacy of the resources devoted to their criminal justice systems. Nevertheless, when the two cities are compared to the many jurisdictions that are more dependent on plea bargaining, the price may seem lower and the currency less debased. Nonjury trials in Philadelphia and Pittsburgh in the mid1960's were public rather than closed-door proceedings; each of the defendants tried in these jurisdictions had an opportunity to present his side of the story to an impartial third party (a procedure that apparently had therapeutic value in itself); and most importantly, defendants in Philadelphia and Pittsburgh did not surren-

489 For example, the harshest treatment of a complaining witness that I have observed occurred in a Pittsburgh courtroom. The case was one of attempted rape by a stranger, and the victim's lack of consent did not seem a disputable issue. On cross-examination, however, the defense attorney asked whether the victim had ever engaged in sexual relations with her fiancé. Moreover, upon receiving her denial, the attorney mocked and taunted the witness in a series of crude and explicit questions. Neither the prosecutor nor the trial judge sought to prevent this abuse, and the defendant seemed thoroughly to enjoy both his lawyer's performance and the witness's discomfort.

400 See, e.g., Enker, Perspectives on Plea Bargaining, in TASK Force on the Admin. of Justice, supra note 80, at 108, 115; Note, Plea Bargaining and the Transformation of the Criminal Process, 90 Harv. L. Rev. 564, 576-77 (1977). 
der their chances for acquittal.

The Philadelphia and Pittsburgh experience also illustrates that, from a social perspective, there is an enormous difference between a simple and expeditious adjudicative procedure and a very elaborate and "safeguarded" settlement procedure, one that is likely to consume as many resources. A person who observes plea negotiation sessions frequently encounters troublesome factual and legal issues that are never resolved. The process truly is one of "split the difference"; opposing lawyers usually reach an accommodation "although the shifting and fallible bases of their conflicting assumptions are never tested." ${ }^{291}$ Nevertheless, most of the disturbing issues that plea negotiation would have left open were resolved authoritatively, effectively, and fairly in short nonjury trials in Philadelphia and Pittsburgh. Even when lawyers were ill-prepared and foundering and essentially left the witnesses to their own devices, the circumstances surrounding most street crimes emerged with clarity in half-hour and forty-five-minute trials. And when, on occasion, important questions remained unanswered at the conclusion of these nonjury trials, courts treated them in the only manner that a decent legal system can-by resolving reasonable doubts in favor of those accused of crimes.

When I returned to Philadelphia and Pittsburgh in 1977, guilty pleas and plea negotiation remained much less frequent than in most other jurisdictions, but they had become substantially more common than they had been nine years earlier. ${ }^{402}$ In Philadelphia, the changes may have resulted partly from a deliberate revision of policy. Arlen Specter, a notable opponent of plea negotiation, had been replaced as district attorney by Emmett Fitzpatrick, who favored the practice. As an assistant district attorney summarized his office's policy:

We have no aversion to plea negotiation in any case in which we believe that we can get more than we give. Still, we recognize that it is usually no more work to try a case on a waiver than to negotiate and formalize a guilty plea. We therefore don't go out of our way to make deals. ${ }^{493}$

In both cities, gradual changes in the trial process may have been more significant than deliberate changes in plea negotiation

491 The Prosecutor's Role, supra note 4, at 71-72.

102 See supra notes 424-26 and accompanying text. 1977).

493 Interview with John Morris, First Ass't District Att'y, in Philadelphia (Dec. 20, 
policy. By 1977, Philadelphia's bizarre but expeditious "crash" court had disappeared, ${ }^{494}$ and although most lawyers and judges in both cities maintained that twenty-minute and half-hour trials still occurred, they agreed that these very rapid trials had become less common than in the past. Indeed, my own visits to "waiver rooms" in Pittsburgh and Philadelphia revealed only two-, three-, and four-hour trials-a dramatic change from the many trials lasting less than an hour that I had observed in 1968.

In Pittsburgh, where the changes were especially pronounced, the quality of lawyers in the public defender and district attorney's offices plainly had improved in the years since my initial study. The more energetic and capable lawyers who had joined these offices may have been more insistent on careful trial practices. Although I continued to observe some departures from evidentiary rules in nonjury trials (frequent leading questions, for example, and one case in which a police officer was permitted to testify without objection to what other officers had done after he had gone off duty), in the main the formalities of the trial process seemed to be observed about as carefully as in most jury trials.

More importantly, in both cities, the level of trial preparation was far higher than it had been in 1968; lawyers on both sides knew their cases well and apparently had spoken with their witnesses before calling them to the stand. Indeed, it is difficult to imagine that these lawyers' cases could have been tried much more thoroughly in jury proceedings lasting three or four times longer. Nevertheless, the greater professionalization that finally had come even to Pittsburgh may have had its darker side. In a small way, it may have had an effect similar to that of the professionalization of the Anglo-American trial generally over the course of a much longer period of time. This professionalization undoubtedly increased the complexity of the trial process and, in the absence of adequate resources, may have increased the administrative pressure for plea negotiation.

The nonjury trials of Philadelphia and Pittsburgh in the mid1960's seemed to indicate that American jurisdictions could reduce their reliance on plea bargaining very substantially by making some sacrifices in the quality of the trial process-sacrifices that, although troublesome, would leave this process far more able to assure the guilt of the people subjected to criminal punishment than the more common plea bargaining alternative. Similarly, the

104 At least it had disappeared from the Court of Common Pleas; I heard rumors that "crash court" procedures still could be found in the Municipal Court of Philadelphia. 
nonjury trials of Pittsburgh and Philadelphia a decade later seemed to indicate that American jurisdictions could reduce their reliance on plea negotiation somewhat less substantially while retaining a trial process in which relevant factual circumstances were developed in a careful, thorough, and professional manner.

To be sure, the implicit "jury waiver bargaining" that still occurred in Philadelphia and Pittsburgh had much in common with plea bargaining and was disturbing for some of the same reasons. Federal and state constitutions guarantee a right to jury trial, ${ }^{495}$ and defendants should not pay the price of added criminal punishment for daring to exercise that right. If, however, the resources that our nation can devote to criminal justice are truly as paltry as many advocates of plea negotiation contend, Philadelphia and Pittsburgh have found a more appropriate way to allocate these resources than most other jurisdictions.

The experience of these two cities indicates that if a legislature were to prohibit plea bargaining without at the same time providing additional funds to courts, prosecutors' offices, and defender agencies, the probable result would be neither evasion nor crisis. Administrators could respond to this prohibition in numerous ways: by eliminating inefficiencies, ${ }^{496}$ by prosecuting less, ${ }^{497}$ by implementing trial reforms, ${ }^{498}$ and, most importantly, by turning from plea bargaining to jury waiver bargaining. In view of the substantial extent to which Philadelphia and Pittsburgh have limited their reliance on plea bargaining despite resource constraints more severe than the norm, most other jurisdictions undoubtedly could substitute jury waiver bargaining for plea bargaining altogether. ${ }^{499}$

Indeed, a proposition about criminal justice reform that may seem too simple to be true may be true in fact. Without elaborate planning, scholarly studies, and additional funding, one effective way to prohibit plea bargaining would be just to prohibit it. Confronted with an immediate and unqualified prohibition, the criminal justice system's powerful mechanisms of bureaucratic adjustment would not wither away. In the absence of dishonesty and

\footnotetext{
${ }^{495}$ See, e.g., U.S. ConST. amend. VI; CaL. ConST. art. I, § 7; ILL. Const. art. I, § 13.

${ }^{488}$ See supra notes $368-75$ and accompanying text.

${ }^{407}$ See supra notes 360-67 and accompanying text.

${ }^{408}$ See supra notes 382-411 and accompanying text.

${ }^{499}$ Indeed, however limited a jurisdiction's resources, it could substitute adjudication for settlement in all cases if its adjudicative procedures were expedited enough. If the sorry choice were presented, for example, a jurisdiction could substitute five-minute trials for fiveminute plea acceptance procedures.
} 
evasion, ${ }^{500}$ however, these mechanisms would match resources to caseloads, not by continuing to provide costly trials to the few while inducing the many to plead guilty, but by affording simpler trials to all who wished to be heard. Moreover, courts whose fears of administrative overload have led them to invoke disingenuous concepts of waiver in support of plea bargaining could invoke the same theories in support of less sweeping waivers by defendants-waivers that could bring an operational trial system into existence without additional resources. In short, if a legislature were to prohibit the exchange of concessions for pleas of guilty without forbidding official concessions for waivers of the right to jury trial, the invisible hand that sometimes is thought to make plea bargaining inevitable could continue its disturbing work. The differing resource limitations of various jurisdictions would be reflected, however, not in varying guilty plea rates or in differing concessions offered for pleas of guilty, but in forms and procedures of the nonjury trials that most defendants would be induced to accept. $^{.01}$

soo See supra notes 141-71 and accompanying text.

${ }^{801}$ Legislatures are not the only potential sources of a plea bargaining prohibition. As I have indicated, the current failure of courts to hold this practice unconstitutional seems better explained by their fear of major change than by the strained doctrinal rationalizations for plea bargaining that they have offered. See supra notes 17-23, 42-46, and accompanying text; The Supreme Court, supra note 4, at 71. Nevertheless, legal and ethical constraints would make it more difficult for a court to substitute "jury waiver bargaining" for plea bargaining than for a legislature to do so. Although a legislature could prohibit plea bargaining without speaking to the question of jury waiver bargaining, any court that held plea bargaining unconstitutional might be required to pass upon the constitutionality of waiver bargaining as well. It would be difficult for a court to uphold this less restrictive form of bargaining while forbidding plea bargaining simply on the theory that the first practice is "less unconstitutional" than the second.

Conceivably, however, an appellate court could adopt a Philadelphia-style solution by avoiding constitutional issues and by relying on its supervisory power over the administration of justice in subordinate courts. Moreover, after holding that some entrenched unconstitutional practices need be eliminated only with "deliberate speed," a court might treat the immediate substitution of a "less unconstitutional" alternative as the first step toward full implementation of constitutional rights. See People v. Byrd, 12 Mich. App. 186, 224, 162 N.W.2d 777, 797 (1968) (Levin, J., concurring) ("The problem is not unlike that of segregated schools in that it is too ingrained to be eliminated forthwith. I suggest that we proceed to its eventual elimination.") (footnote omitted).

Of course, prior to the decision in Duncan v. Louisiana, 391 U.S. 145 (1968), there would have been a clear constitutional basis for distinguishing plea bargaining from jury waiver bargaining. Because the right to jury trial had not been "incorporated" in the fourteenth amendment's due process clause, jury waiver bargaining in the state courts would not have burdened the exercise of a federal constitutional right. At the same time, the right to some kind of impartial trial always has been at the core of due process concepts. A practice like plea bargaining, whose very purpose is to prevent large numbers of defendants from obtaining trials of any kind, would have raised substantial issues even in the earliest days of 


\section{E. Jury Waiver Bargaining and Sentencing Reform}

Although this article has argued that the jury waiver bargaining of Philadelphia and Pittsburgh is superior to the plea bargaining of other jurisdictions, a more satisfactory system of waiver bargaining could emerge from the development of sentencing guidelines that would both prohibit the imposition of a penalty for insistence upon a nonjury trial and articulate limitations on the extent to which conviction by a jury could lead to a more severe sentence. Moreover, to view these same reforms from a different perspective, the substitution of jury waiver bargaining for plea bargaining could help to resolve serious difficulties that have plagued recent sentencing reform efforts.

At the same time that a number of states have reduced substantially the sentencing discretion of trial judges and parole boards, ${ }^{502}$ plea negotiation has remained virtually immune from serious reform efforts. ${ }^{.03}$ When judged by any criterion other than the self-interest and political power of lawyers, this disparate treatment of plea bargaining and other forms of sentencing discretion seems odd. There is almost no objection to the sentencing power of judges and parole boards that does not apply in full measure to the sentencing power that prosecutors and defense attorneys exercise in plea bargaining; there are many objections to plea -bargaining that have little or no application to judicial sentencing and parole. ${ }^{504}$ So long as prosecutors retain an unchecked power to bargain, progress toward certainty in sentencing will remain marginal. Indeed, a determinate sentencing scheme may produce its antithesis-"a system every bit as lawless as the current sentencing

fourteenth amendment jurisprudence. See, e.g., Fay v. New York, 332 U.S. 261, 288 (1947) (it is "inherent in the independent concept of due process that condemnation shall be rendered only after a trial, in which the hearing is a real one, not a sham or pretense"); Palko v. Connecticut, 302 U.S. 319, 327 (1937) ("[f] undamental too in the concept of due process, and so in that of liberty, is the thought that condemnation shall be rendered only after trial"); Jordan v. Massachusetts, 225 U.S. 167, 176 (1912) (the requirements of due process "are complied with, provided in the proceedings which are claimed not to have been due process of law the person condemned has had sufficient notice and adequate opportunity has been afforded him to defend"); Hurtado v. California, 110 U.S. 516, 535 (1884) (indicating that to be consistent with the fourteenth amendment a state procedure must be one that "renders judgment only after trial").

${ }_{s 02}$ See, e.g., Cal. Penal Code $\S 1170$ (a)(1) (West Supp. 1981); Colo. Rev. Stat. § 18-1102.5 (Supp. 1982). Professor Michael Tonry reported in 1981 that since 1976 more than 20 states had enacted major sentencing reforms. Tonry, Real Offense Sentencing: The Model Sentencing and Correction Act, 72 J. Crim. L. \& Criminology 1550, 1551 (1981).

${ }^{\text {sos }}$ See Tonry, supra note 502, at 1554 ("Not one of the major new sentencing systems faces up to the squalid reality that most guilty pleas are induced by promises of leniency.").

sot See Sentencing Reform, supra note 4, at 564. 
regime, in which discretion is concentrated in an inappropriate agency, and in which the benefits of this discretion are made available only to defendants who sacrifice their constitutional rights."

Recent sentencing reform efforts have succeeded in focusing attention on what once were called hidden issues of sentencing. Some of the most troublesome of these issues have arisen from America's misuse of sentencing power to avoid the burdens of trial. Scholars have debated the question of "real offense sentencing"-whether an offender's sentence should be based on what he did or on the artificial label that his crime may bear when it emerges from the plea bargaining process. ${ }^{608}$ They have considered whether statutes or administrative guidelines should specify a precise "guilty plea discount"-a predetermined reduction in sentence that a defendant would secure automatically by submitting a plea of guilty. ${ }^{\mathrm{soz}}$

Legislative or administrative designation of the reward that would follow a guilty plea would accord with the logic of today's search for certainty in sentencing. If the submission of a guilty plea were treated no differently from other mitigating circumstances whose significance was specified in a statute or administrative guideline (and of course if plea bargaining by prosecutors were prohibited), the reduction of sentence that followed the entry of a guilty plea would not depend on the host of whims and penologically irrelevant considerations that commonly influence plea bargaining today. ${ }^{.08}$

sos Id. at 551. Although this previous article emphasized the likelihood that sentencing reform efforts would enhance the bargaining power of prosecutors, it also noted that most real world reform proposals were characterized by countervailing tendencies and that the prediction of results was perilous. It concluded, "Determinate sentencing statutes may not always make things worse, but unless they achieve a major restriction of prosecutorial power, the reformers will not accomplish the goal of more certain sentencing . . . ." Id. at 576.

100 See, e.g., Alschuler, Sentencing Reform and Parole Release Guidelines, 51 U. CoLo. L. REv. 237, 241-44 (1980); Schulhofer, Due Process of Sentencing, 128 U. PA. L. REv. 733, 757-72 (1980); Schwartz, Options in Constructing a Sentencing System: Sentencing Guidelines Under Legislative or Judicial Hegemony, 67 VA. L. REv. 637, 680-84 (1981); Tonry, supra note 502.

${ }^{807}$ See, e.g., Coffee, "Twisting Slowly in the Wind": A Search for Constitutional Limits on Coercion of the Criminal Defendant, 1980 Sup. CT. Rzv. 211, 246 \& n.132; Gifford, supra note 38, at 80; Kaplan, Observation: American Merchandising and the Guilty Plea: Replacing the Bazaar with the Department Store, 5 AM. J. CRIM. L. 215, 222-23 (1977); Perlman \& Stebbins, Implementing an Equitable Sentencing System: The Uniform Law Commissioners' Model Sentencing and Corrections Act, 65 VA. L. REv. 1175, 1264-65 (1979); Schulhofer, supra note 506, at 778-98; Tonry, supra note 502, at 1555 \& n.20; Vorenberg, Decent Restraint of Prosecutorial Power, 94 HARv. L. RBv. 1521, 1560-61 (1981).

Sentencing Reform, supra note 4, at 575. 
Nevertheless, the direct specification by a legislature or sentencing commission of a guilty plea discount or a fixed "tariff" for exercise of the right to trial seems unpalatable. ${ }^{.09}$ For one thing, some defenders of plea bargaining might object in principle to the development of uniform sentence differentials. ${ }^{510}$ More importantly, open articulation of the sentencing practices that now make the bargaining process effective would raise issues that most plea bargaining proponents probably would prefer to keep hidden-whether, for example, the sentence imposed following a conviction at trial should be $10 \%$ or $500 \%$ higher than the sentence that would have been imposed following a guilty plea. Finally, people who hope for an eventual prohibition of plea bargaining also would be likely to oppose the explicit approval of sentence differentials.

In a system of jury waiver bargaining, however, the recognition, regularization, and limitation of sentence differentials might be more feasible. First, a legislature might prohibit both plea bargaining and jury waiver bargaining by prosecutors-a step that would restore sentencing power to the judiciary and eliminate the intriguing but plainly insoluble problem of "real offense sentencing." S11 Second, rather than articulate inflexible sentencing tariffs for all convicted defendants who have exercised the right to be heard, a legislature or a sentencing commission might develop guidelines expressing the following principles:

1. Because the right to a hearing before an impartial judicial tribunal is fundamental, no sentencing tariff may be imposed for demanding a trial by the court without a jury;

2. A sentencing tariff sometimes may be imposed for exercise of the right to jury trial, but not an extreme or "unconscionable" tariff;

3. The sometimes permissible jury tariff must be withheld when a convicted defendant has raised issues that a jury ought to have heard-for example, when he has advanced an insanity defense supported by plausible expert testimony.

These principles would represent so substantial a step away

${ }^{809}$ See Perlman \& Stebbins, supra note 507, at 1264-65.

s10 See The Trial Judge's Role, supra note 4, at 1127-28.

s11 On the insolubility of the issue of real offense sentencing, see 1 RESEARCH ON SENTENCING, supra note 155, at 152; Alschuler, supra note 506, at 243. On whether a prohibition of prosecutorial bargaining could be enforced effectively, see supra notes 141-71 and accompanying text.

${ }^{\text {s12 }}$ Cf. U.C.C. \& 2-302 (1978) (unconscionable contract provisions unenforceable). 
from present practices and toward the civilized administration of justice that plea bargaining proponents might not blush at their openness, and plea bargaining opponents might not resist the imprimatur that they would give to one form of differential sentencing.

An attempt by a legislature or sentencing commission to specify in advance precisely the effect that conviction by a jury would have upon sentencing in various sorts of cases would be artificial-the product mostly of guesswork. A better course would be to provide for the appellate review of sentences. A process of judicial inclusion and exclusion gradually could give content to the concept of the "triable" case (the sort of case in which any jury trial tariff would be inappropriate), and to the concept of "unconscionability" (a concept that would limit the extent of the sentence differential in "nontriable" cases). ${ }^{\text {s13 }}$ Within whatever limits appellate courts established, a trial judge might consider resource limitations and the press of judicial business in deciding on a case-by-case basis whether any jury trial tariff was appropriate and, if so, how large it should be. If many defendants continued to plead guilty despite the prohibition of plea bargaining, if legislatures allocated additional resources to trial courts, if these courts began to use their current capacities more effectively, or if a generous implementation of the right to jury trial seemed feasible for other reasons, trial judges might decide to eliminate the jury trial tariff altogether or else to hold it well below the level that would raise issues of unconscionability.

To speak in these terms is admittedly troublesome. Justice for criminal defendants should not consist of choosing the best plan for spreading existing resources, however meager, to cover existing caseloads. ${ }^{514}$ This article has recognized that Philadelphia's less re-

s13 An appellate court's ability to determine whether an unconscionable tariff had been imposed following conviction by a jury (and whether any sentencing tariff had been imposed following conviction by a court) would depend upon its ability to distinguish the "trial tariff" from the "baseline" sentence. A scheme of sentencing guidelines probably would need to be reasonably precise to permit the appellate court to make this judgment. Nevertheless, the court could permit departures from the guidelines so long as these departures were explained in terms that the court was persuaded did not mask impermissible tariffs. Of course, if both trial and appellate courts winked at improper differentials and disingenuous explanations, the scheme would collapse, but so long as an effective match of caseload and resources was achieved, the principal impetus for this evasion would be lacking.

o14 From my perspective, proposing the Pittsburgh-Philadelphia alternative to plea bargaining is somewhat akin to urging a person to refrain from robbery on the ground that as much money can be obtained by shoplifting. A person who offered this advice might well be punished as an accomplice to whatever shoplifting was committed by a person who followed it. Nevertheless, some forms of theft truly are less objectionable than others. 
strictive alternative is still restrictive. This waiver bargaining alternative not only delivers less than the law promises but also makes criminal sentences depend in part on the mode of trial demanded in individual cases. Either a full implementation of the right to jury trial without shortcuts or a direct, nonbargained simplification of trial procedures would avoid these defects and accordingly would seem preferable. ${ }^{515}$

Nevertheless, the proposed system of jury waiver bargaining responds to the principal concerns of many proponents of plea bargaining. It would permit trial judges to discourage the use of an extraordinarily expensive trial mechanism in cases presenting only insubstantial issues, and it would provide a safety valve that would enable these judges, within limits established by law, to match resources to caseloads. At the same time, this proposal would prohibit both explicit and implicit plea bargaining and afford an unfettered right to a simplified form of trial to every criminal defendant. Our nation could conserve its resources and still implement procedures that would allow defendants a greater opportunity to be heard, lead to acquittal when guilt could not be proven beyond a reasonable doubt, and resolve criminal disputes on the merits rather than adjudge most defendants half guilty in a spirit of indeterminacy and compromise.

\section{Conclusion}

The impediments to implementation of a plea bargaining prohibition are not worth a fraction of the paralysis that they have prompted. Americans certainly could afford full implementation of the right to jury trial in both felony and misdemeanor prosecutions. Moreover, without additional expenditures, they could allocate existing resources more effectively by simplifying the trial process and making trials more available. Finally, states could easily substitute jury waiver bargaining for plea bargaining. Observers who proclaim that implementation of the right to trial is impossible have perpetrated a remarkable myth-one whose effectiveness depends largely on the "outsider's" fear of being thought naive or utopian and one that any glance outside our own legal system destroys.

At the end of a long investigation of plea bargaining, I confess

518 Nevertheless, one might prefer a system of jury waiver bargaining to a direct simplification of trial procedures on the ground that it would give those defendants willing to risk a sentencing tariff the traditional jury trial option. For a discussion of some reasons why I do not find this argument persuasive, see The Changing Debate, supra note 4. 
to some bafflement concerning the insistence of most lawyers and judges that plea bargaining is inevitable and desirable. Perhaps I am wrong in thinking that a few simple precepts of criminal justice should command the unqualified support of fair-minded people:

-that it is important to hear what someone may be able to say in his defense before convicting him of crime;

-that, when he denies his guilt, it is also important to try to determine on the basis of all the evidence whether he is guilty;

-that it is wrong to punish a person, not for what he did, but for asking that the evidence be heard (and wrong deliberately to turn his sentence in significant part on his strategies rather than on his crime);

-and, finally, that it is wrong to alibi departures from these precepts by saying that we do not have the time and money to listen, that most defendants are guilty anyway, that trials are not perfect, that it is all an inevitable product of organizational interaction among stable courtroom work groups, and that any effort to listen would merely drive our failure to listen underground.

From my viewpoint, it is difficult to understand why these precepts are controversial; what is more, I do not understand why the legal profession, far from according them special reverence, apparently values them less than the public in general does. ${ }^{516}$ Daniel Webster thought it a matter of definition that "law" would hear before it condemned, proceed upon inquiry, and render judgment

s16 Professor Stephen J. Schulhofer once wrote that a paper like this one ought to consider not only the economic feasibility of prohibiting plea bargaining but the political feasibility of doing it as well. Schulhofer, supra note 506, at 779 n.184. I claim no powers of political punditry, but I once expressed some views on the issue in a conversation with a congressional staff member who had asked what position I thought the Chairman of the Senate Judiciary Committee ought to take. When I suggested that the Senator ought to introduce legislation to prohibit plea bargaining, the staff member appeared somewhat stunned. "My goodness," he said, "we'd have the United States Attorneys against us, and the federal judges, and the defense attorneys too."

"Yes," I replied, "and who else?" The staff member's comment obviously had not accounted for as much as one percent of the voting population.

Plea bargaining is a "strange bedfellows" issue that typically unites the president of the inmates' union and the local police chief in denouncing the hypocrisy of the criminal justice system. Although lawyers tend to approve of the practice, corrections officials, police officers, victims of crime, civil libertarians, "law and order" conservatives, and most other members of the public tend not to. The only public opinion poll on the issue of which I am aware showed $70 \%$ of those polled opposed to the practice and $21 \%$ in favor. D. Foger, “. . . We Are the Living Proof . . ." 300 (app. III) (1975). A basic question comes to mind: Who owns the criminal justice system? 
only after trial. ${ }^{512}$ Apparently the legal profession has lost sight of Webster's kind of law, and, for all the pages that I have written about plea bargaining, the issue in the end may be that simple.

s17 Trustees of Dartmouth College v. Woodward, 17 U.S. (4 Wheat.) 518, 581 (1819) (argument of D. Webster for plaintiffs in error, Mar. 10, 1818), reprinted in $5 \mathrm{D}$. WEBSTER, The Works of Daniel Webster 487-88 (Boston 1851). 